Nicolle Miranda de Lima

\title{
Análise do Deslocamento de Óleo por Soluções Poliméricas em Microescala
}

Dissertação de Mestrado

Dissertação apresentada como requisito parcial para obtenção do grau de Mestre pelo Programa de Pósgraduação em Engenharia Mecânica da PUC-Rio.

Orientador: Prof. Márcio da Silveira Carvalho 


\section{Análise do Deslocamento de Óleo por Soluções Poliméricas em Microescala}

Dissertação apresentada como requisito parcial para obtenção do grau de Mestre pelo Programa de Pós-graduação em Engenharia Mecânica do Departamento de Engenharia Mecânica do Centro Técnico Científico da PUC-Rio. Aprovada pela Comissão Examinadora abaixo assinada.

Prof. Márcio da Silveira Carvalho

Orientador

Departamento de Engenharia Mecânica - PUC - Rio

Prof. $^{a}$ Mônica Feijó Naccache

Departamento de Engenharia Mecânica - PUC - Rio

Prof. Arturo Rodrigo Ferreira Pardo Departamento de Engenharia de Petróleo - UFF

Prof. José Eugenio Leal Coordenador do Centro Técnico Científico - PUC - Rio

Rio de Janeiro, 16 de setembro de 2015. 
Todos os direitos reservados. É proibida a reprodução total ou parcial do trabalho sem autorização da universidade, da autora e do orientador.

\section{Nicolle Miranda de Lima}

Nicolle Miranda de Lima graduou-se em Engenharia de Petróleo pela Universidade Federal Fluminense [2013].

Ficha catalográfica

Lima, Nicolle Miranda de

Análise do Deslocamento de Óleo por Soluções Poliméricas em Microescala/ Nicolle Miranda de Lima; orientador: Márcio da Silveira Carvalho. - 2015.

80 f.: il. (color.) ; $29,7 \mathrm{~cm}$

Dissertação (mestrado) - Pontifícia Universidade Católica do Rio de Janeiro, Departamento de Engenharia Mecânica, 2015.

Inclui referências bibliográficas.

1. Engenharia Mecânica - Teses. 2. Recuperação Avançada de Óleo. 3. Injeção de Soluções Poliméricas. 4. Microfluídica. 5. Viscoelasticidade. I Carvalho, Márcio da Silveira. II. Pontifícia Universidade Católica do Rio de Janeiro. Departamento de Engenharia Mecânica. III. Título. 


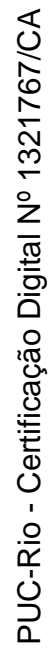

A Deus, por tudo que me proporciona

na vida. 


\section{Agradecimento}

Agradeço a meus pais e minhas irmãs pelo amor incondicional, pelo apoio e incentivo na busca pelos meus sonhos.

Meu namorado Matheus por estar sempre ao meu lado, por me dar forças para não desistir diante das dificuldades, pelo carinho e cuidado de sempre.

Ao meu orientador Professor Márcio pela paciência e incentivo, e pela dedicação e amor que demonstra em tudo que faz.

Aos colegas de pesquisa do Laboratório de Micro-Hidrodinâmica e Meios Porosos, amigos e professores da PUC-Rio pelo suporte e amizade.

A CAPES e a PUC-Rio pelos auxílios concedidos, sem os quais este trabalho não poderia ter sido realizado.

A Statoil pelo incentivo e apoio financeiro à pesquisa.

E todos aqueles que neste período estiveram presentes e contribuíram para a minha caminhada. 


\section{Resumo}

Lima, Nicolle Miranda de; Carvalho, Márcio da Silveira. Análise do Deslocamento de Óleo por Soluções Poliméricas em Microescala. Rio de Janeiro, 2015. 80p. Dissertação de Mestrado - Departamento de Engenharia Mecânica, Pontifícia Universidade Católica do Rio de Janeiro.

A injeção de água é o método de recuperação secundária mais utilizado na indústria do petróleo. No entanto, a alta razão de mobilidade entre a água e o óleo limita a quantidade de óleo deslocada. Uma alternativa para minimizar este problema é a aplicação de tecnologias que agem como agentes de controle da mobilidade. Soluções poliméricas podem ser utilizadas para aumentar a viscosidade da água e consequentemente reduzir a razão de mobilidade. Evidências experimentais têm mostrado que o comportamento elástico de soluções poliméricas pode além de diminuir a razão de mobilidade, contribuir para um melhor deslocamento de óleo em escala de poro, reduzindo a saturação de óleo residual. Esse comportamento em escala de poro ainda não está completamente entendido. Nesse trabalho, um micromodelo de vidro formado por uma rede bi-dimensional de canais foi utilizado como meio poroso. Esse dispositivo tem algumas características importantes de meios porosos e permite a visualização do fluxo em escala de poro. A evolução do deslocamento de óleo pela fase aquosa é acompanhada no microscópio e são obtidas imagens dos perfis de saturação. Três diferentes fases aquosas foram usadas: água deionizada, uma solução de poli(óxido de etileno) de alto peso molecular e uma mistura de água com glicerina com a mesma viscosidade do poli(óxido de etileno). A visualização do fluxo no micromodelo permite obter informações específicas sobre a presença de óleo preso por forças capilares e o movimento da interface óleo/água no interior da rede. Resultados mostraram que as forças viscoelásticas modificam a distribuição de fluidos no meio poroso, melhorando a eficiência de deslocamento em escala de poro e consequentemente a saturação de óleo residual.

\section{Palavras-chave}

Recuperação Avançada de Óleo; Injeção de Soluções Poliméricas; Viscoelasticidade; Microfluídica 


\section{Abstract}

Lima, Nicolle Miranda de; Carvalho, Márcio da Silveira (Advisor). Porescale analysis of oil displacement by polymer solution. Rio de Janeiro, 2015. 80p. MSc. Dissertation - Departamento de Engenharia Mecânica, Pontifícia Universidade Católica do Rio de Janeiro.

Water flooding is the most commonly used oil recovery method in the oil industry. However, the high mobility ratio between the water and oil phases limits the amount of oil displaced by the water phase. An effective alternative to minimize this problem is the application of technologies that act as mobility control agents. Polymer solution is used in many cases as a way to increase the water phase viscosity and consequently reduce the mobility ratio. Experimental evidences have shown that the elastic behavior of some polymer solution may not only improve the mobility ratio but also contribute to a better pore level oil displacement, reducing the residual oil saturation. This pore level behavior is not clearly understood. In this work, a glass microfluidic chip made of a 2-D array of channels is used as a two-dimensional porous space. This device has the principal features of a porous media and provides means for pore level flow visualization. A microscopic is used to monitor the evolution of the water phase as it displaces oil and images of the saturation profiles can be made. Three different water phases were used: pure water, a high molecular weight poly(ethylene oxide) solution and a glycerol-water mixture with the same viscosity of the polymer solution. Flow visualization provides specific information about the presence of the trapped oil phase and the movement of the oil/water interface in the network. Results show that the viscoelastic forces modify the liquid distribution in the porous media, improving the displacement efficiency at pore scale and consequently the residual oil saturation.

\section{Keywords}

Enhanced Oil Recovery; Polymer Solution Injection; Viscoelasticity; Microfluidics 


\section{Sumário}

1 Introdução 15

1.1. Descrição geral do problema 15

$\begin{array}{ll}\text { Injeção de água } & 15\end{array}$

$\begin{array}{ll}\text { Injeção de soluções poliméricas } & 17\end{array}$

Micromodelos e sua utilização em escoamento em meios porosos 20

1.2. Objetivos do trabalho 23

2 Abordagem experimental $\quad 24$

2.1. Bancada experimental 24

2.1.1. Micromodelo de vidro 25

2.1.2. Sistema de injeção de fluidos 28

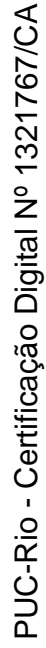

2.1.3. Sistema de visualização do fluxo através do meio poroso 30

2.1.4. Sistema para processamento de imagens 31

2.2. Materiais 31

2.2.1. Óleo 31

2.2.2. Solução polimérica 32

2.2.3. Água destilada e solução de glicerina 38

2.3. Procedimento experimental 39

3 Resultados 43

3.1. Procedimento $1 \quad 45$

3.2. Procedimento $2 \quad 56$

3.2.1. Região $A 1 \quad 57$

3.2.2. Região A2 59

3.2.3. Região A3 61

3.2.4. Região A4 63

3.2.5. Região A5 65

3.2.6. Região A6 67

4 Comentários finais $\quad 73$

4.1. Sugestões $\quad 74$ 
5 Referências Bibliográficas

A Código em MATLAB

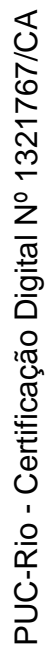




\section{Lista de figuras}

Figura 1 - Injeção de água (SANTOS et al., 2010) 16

Figura 2 - Viscous fingering (SANTOS et al., 2010) 17

Figura 3 - Comparação entre a injeção de água e a injeção de soluções poliméricas (GREEN; WILLHITE, 1998) 17

Figura 4 - Resultados obtidos por Wang e outros (2000) 19

Figura 5 - Solução polimérica deslocando gânglio de óleo 20

Figura 6 - Micromodelo utilizado por Berejnov et al (2008) (a) e alguns

resultados obtidos experimentalmente (pode-se observar a

frente de avanço em um meio poroso regular (b) e irregular (c)

$\begin{array}{ll}\text { totalmente saturado de } a r) & 21\end{array}$

Figura 7 - Dispositivo utilizado por Buchgraber et al (2009) e imagem microscópica do meio poroso $\quad 21$

Figura 8 - Resultados obtidos com solução salina (esquerda) e com solução polimérica (direta) (BUCHGRABER et al., 2009) 22

Figura 9 - Micromodelo utilizado por Kumar Gunda et al (2011) 22

Figura 10 - Distribuição dos fluidos no meio poroso antes e após a injeção de água (KUMAR GUNDA et al., 2011) 22

Figura 11 - Meio poroso utilizado por Nilsson e colaboradores (2013)

e a geometria observada no microscópio 23

Figura 12 - Bancada experimental $\quad 24$

Figura 13 - Esquema da banca experimental $\quad 25$

Figura 14 - Micromodelo de vidro $\quad 25$

Figura 15 - Dimensões do micromodelo, dimensões do canal e vista macroscópica do meio poroso 26

Figura 16 - Constrições e arranjo dos canais $\quad 27$

Figura 17 - Multiflux ${ }^{T M}$ 4-way linear connector $\quad 27$

Figura 18 - Bombas de seringa Harvard Apparatus e seringas Hamilton 29

Figura 19 - Válvula SOLIDOR, conector e mangueira 29

Figura 20 - Microscópio Carl Zeiss modelo Axiovert 40MAT 30

Figura 21 - Câmera PixeLINK PL-a662 30

Figura 22 - Fórmula estrutural e polímero utilizado para os experimentos (MM=8,000,000 g/mol, produzido pela Sigma-Aldrich) 32

Figura 23 - Preparo da solução 33 
Figura 24 - Picnômetro

Figura 25 - Tensiômetro Tracker TECLIS 34

Figura 26 - Reômetro rotacional $\quad 35$

Figura 27 - Gráfico da viscosidade do PEO variando com a taxa de cisalhamento para diferentes concentrações

Figura 28 - Reômetro Haake CaBER e comportamento de fluidos submetidos a extensão

Figura 29 - Gráfico da viscosidade extensional aparente como uma função da taxa de deformação 37

Figura 30 - Banho LAUDA Viscotemp 15 e viscosímetro Ubbelohde 38

Figura 31 - Sistema de filtração e bomba de vácuo 40

Figura 32 - Limpeza do dispositivo $\quad 40$

Figura 33 - Etapas do código em MATLAB 42

Figura 34 - Curva da viscosidade em função da taxa de cisalhamento no intervalo entre 1 e 1000 1/s

Figura 35 - Áreas analisadas no micromodelo

Figura 36 - Perfis de saturação ao final da injeção a 0,039 ml/h na região $A 3$ e as saturações de óleo residual

Figura 37 - Perfis de saturação ao final da injeção a 0,065 ml/h na região $A 3$ e as saturações de óleo residual

Figura 38 - Perfis de saturação ao final da injeção a $0,13 \mathrm{ml} / \mathrm{h}$ na região $A 3$ e as saturações de óleo residual

Figura 39 - Perfis de saturação ao final da injeção a 0,26 ml/h na região $A 3$ e as saturações de óleo residual

Figura 40 - Perfis de saturação ao final da injeção a $0,52 \mathrm{ml} / \mathrm{h}$ na região $A 3$ e as saturações de óleo residual

Figura 41 - Perfis de saturação ao final da injeção a 1,04 ml/h na região $A 3$ e as saturações de óleo residual

Figura 42 - Perfis de saturação ao final da injeção a 1,56 ml/h na região $A 3$ e as saturações de óleo residual

Figura 43 - Perfis de saturação ao final da injeção a 2,08 ml/h na região $A 3$ e as saturações de óleo residual

Figura 44 - Perfis de saturação ao final da injeção a 0,039 ml/h na região $A 4$ e as saturações de óleo residual

Figura 45 - Perfis de saturação ao final da injeção a 0,065 ml/h na região $\mathrm{A} 4$ e as saturações de óleo residual 
Figura 46 - Perfis de saturação ao final da injeção a $0,13 \mathrm{ml} / \mathrm{h}$ na região $A 4$ e as saturações de óleo residual

Figura 47 - Perfis de saturação ao final da injeção a $0,26 \mathrm{ml} / \mathrm{h}$ na região $A 4$ e as saturações de óleo residual

Figura 48 - Perfis de saturação ao final da injeção a $0,52 \mathrm{ml} / \mathrm{h}$ na região $A 4$ e as saturações de óleo residual

Figura 49 - Perfis de saturação ao final da injeção a 1,04 ml/h na região $\mathrm{A} 4$ e as saturações de óleo residual

Figura 50 - Perfis de saturação ao final da injeção a 1,56 ml/h na região $\mathrm{A} 4$ e as saturações de óleo residual

Figura 51 - Perfis de saturação ao final da injeção a 2,08 ml/h na região A4 e as saturações de óleo residual

Figura 52 - Saturação de óleo residual em função do número de capilaridade nas regiões ilustradas (A3 e A4)

Figura 53 - Perfis de saturação ao final da injeção a 0,065 ml/h na região $A 1$ e as saturações de óleo residual

Figura 54 - Perfis de saturação ao final da injeção a $0,52 \mathrm{ml} / \mathrm{h}$ na região $A 1$ e as saturações de óleo residual

Figura 55 - Perfis de saturação ao final da injeção a 2,08 ml/h na região $A 1$ e as saturações de óleo residual

Figura 56 - Perfis de saturação ao final da injeção a 4,16 ml/h na região $A 1$ e as saturações de óleo residual

Figura 57 - Perfis de saturação ao final da injeção a 0,065 ml/h na região $\mathrm{A} 2$ e as saturações de óleo residual

Figura 58 - Perfis de saturação ao final da injeção a $0,52 \mathrm{ml} / \mathrm{h}$ na região $\mathrm{A} 2$ e as saturações de óleo residual

Figura 59 - Perfis de saturação ao final da injeção a 2,08 ml/h na região $\mathrm{A} 2$ e as saturações de óleo residual

Figura 60 - Perfis de saturação ao final da injeção a 4,16 ml/h na região $A 2$ e as saturações de óleo residual

Figura 61 - Perfis de saturação ao final da injeção a 0,065 ml/h na região $A 3$ e as saturações de óleo residual

Figura 62 - Perfis de saturação ao final da injeção a 0,52 ml/h na região $A 3$ e as saturações de óleo residual

Figura 63 - Perfis de saturação ao final da injeção a 2,08 ml/h na região $A 3$ e as saturações de óleo residual 
Figura 64 - Perfis de saturação ao final da injeção a 4,16 ml/h na região $A 3$ e as saturações de óleo residual

Figura 65 - Perfis de saturação ao final da injeção a 0,065 ml/h na região $A 4$ e as saturações de óleo residual

Figura 66 - Perfis de saturação ao final da injeção a $0,52 \mathrm{ml} / \mathrm{h}$ na região $\mathrm{A} 4$ e as saturações de óleo residual

Figura 67 - Perfis de saturação ao final da injeção a 2,08 ml/h na região $\mathrm{A} 4$ e as saturações de óleo residual

Figura 68 - Perfis de saturação ao final da injeção a 4,16 ml/h na região $A 4$ e as saturações de óleo residual

Figura 69 - Perfis de saturação ao final da injeção a 0,065 ml/h na região A5 e as saturações de óleo residual

Figura 70 - Perfis de saturação ao final da injeção a $0,52 \mathrm{ml} / \mathrm{h}$ na região $A 5$ e as saturações de óleo residual

Figura 71 - Perfis de saturação ao final da injeção a 2,08 ml/h na região $\mathrm{A} 5$ e as saturações de óleo residual Figura 72 - Perfis de saturação ao final da injeção a 4,16 ml/h na região A5 e as saturações de óleo residual

Figura 73 - Perfis de saturação ao final da injeção a 0,065 ml/h na região $A 6$ e as saturações de óleo residual Figura 74 - Perfis saturação ao final da injeção a $0,52 \mathrm{ml} / \mathrm{h}$ na região $A 6$ e as saturações de óleo residual Figura 75 - Perfis de saturação ao final da injeção a 2,08 ml/h na região $A 6$ e as saturações de óleo residual Figura 76 - Perfis de saturação ao final da injeção a 4,16 ml/h na região $A 6$ e as saturações de óleo residual

Figura 77 - Gânglios de óleo (Procedimento 2 - taxa de injeção de $4,16 \mathrm{ml} / \mathrm{h}$ - região $\mathrm{A} 4$ )

Figura 78 - Gráfico da saturação de óleo residual em função do número de capilaridade para as três fases aquosas 


\section{Lista de tabelas}

Tabela 1 - Propriedades gerais do micromodelo 28

Tabela 2 - Propriedades do Drakeol® $7 \quad 31$

Tabela 3 - Tensão interfacial $\quad 34$

Tabela 4 - Viscosidade das misturas de água com glicerina 39

Tabela 5 - Valores dos coeficientes $n$ e $k$ 


\section{Introdução}

\section{1.}

Descrição geral do problema

A demanda de energia global vem aumentando substancialmente com o passar dos anos, sendo necessário o desenvolvimento de tecnologias que busquem um melhor aproveitamento dos recursos naturais provenientes de hidrocarbonetos.

Para produzir, os reservatórios necessitam de determinada energia, conhecida como energia primária, que depende de diversas condições do reservatório como volume, porosidade, permeabilidade, pressão e temperatura, e propriedades dos fluidos como viscosidade, densidade e teor de impurezas.

Com o passar do tempo, o reservatório perde uma parcela dessa energia e a pressão começa a diminuir o que implica na redução da produção. Podem ser então empregados mecanismos suplementares de recuperação de petróleo, que podem ser secundários e terciários (recuperação avançada).

No presente trabalho, o foco é o estudo do método de recuperação avançada de injeção de soluções poliméricas e sua influência no aumento da produção de óleo.

\section{Injeção de água}

A injeção de água é um método secundário de recuperação, utilizado em campos onshore e offshore, que consiste na injeção de água no reservatório com o objetivo de aumentar a pressão, deslocar o óleo para os poços produtores, e consequentemente estimular a produção de óleo.

A água é injetada para deslocar o óleo em direção ao poço produtor. (Fig. 1). Pode ter quatro origens diferentes, água subterrânea coletada em subsuperfície através de poços, água de superfície coletada em rios e lagos, água do mar e água produzida (associada à produção de petróleo). 


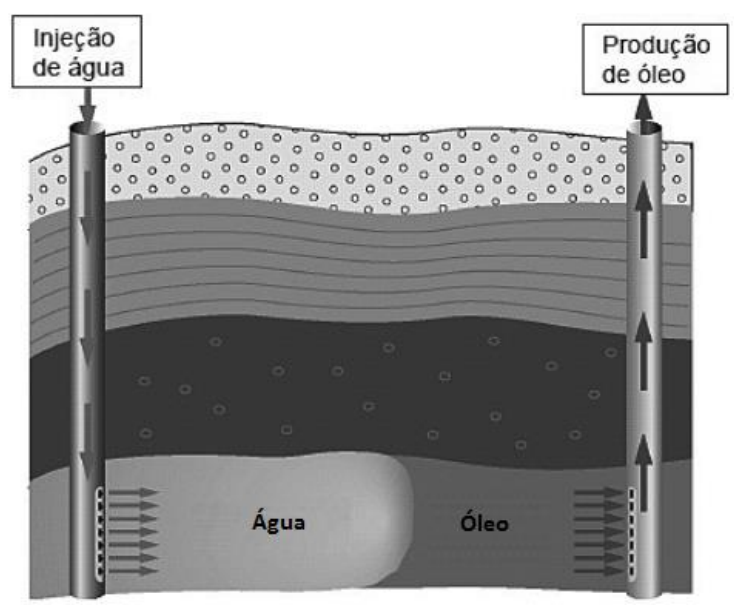

Figura 1 - Injeção de água (SANTOS et al., 2010)

A utilização do processo de injeção de água é responsável por mais da metade da produção mundial de óleo, porém esta metodologia possui uma eficiência de varredura do reservatório limitada, deixando normalmente uma considerável quantidade de óleo no reservatório. Isso ocorre, dentre outros motivos, devido à razão desfavorável de mobilidade entre a água e o óleo, causada pela menor viscosidade da água em comparação com o óleo, na maioria dos reservatórios. (MONTALVO, 2008)

$$
M=\left(\frac{k_{\text {água }} / \mu_{\text {água }}}{k_{\text {óleo }} / \mu_{\text {óleo }}}\right)
$$

onde:

M é a razão de mobilidade

$k_{\text {água }}$ é a permeabilidade efetiva a agua

$k_{\text {óleo }}$ é a permeabilidade efetiva ao óleo

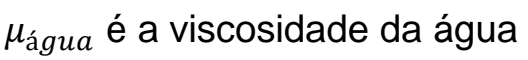

$\mu_{\text {óleo }}$ é a viscosidade do óleo.

A alta razão de mobilidade $M$ leva ao aparecimento de um fenômeno conhecido como viscous fingering. A frente de deslocamento torna-se instável, formando caminhos preferenciais para a fase aquosa, como esquematizado na Figura 2. A água alcança os poços produtores com grande parte do reservatório não sendo varrido. 


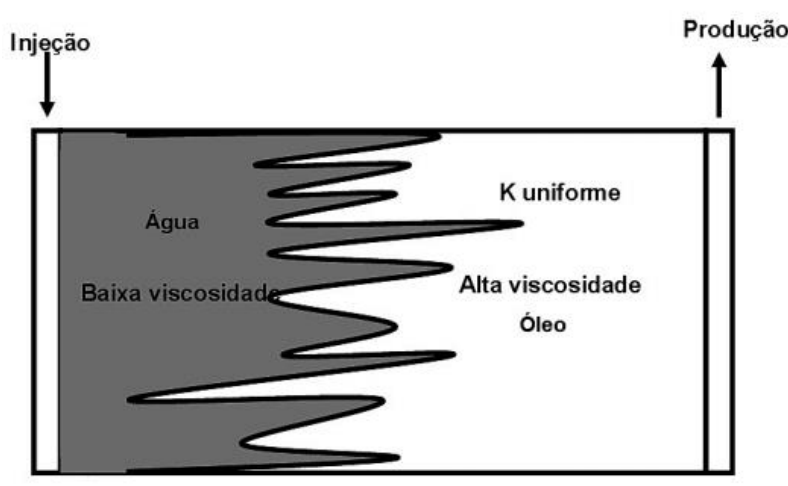

Figura 2 - Viscous fingering (SANTOS et al., 2010)

A presença de viscous fingering em sistemas de produção de óleo com recuperação secundária implantada deve salientar a importância de se conhecer as propriedades físico-químicas que interferem no sistema. Dentre elas, a densidade, a viscosidade e a tensão interfacial, principalmente na região de contato entre o óleo e a água.

\section{Injeção de soluções poliméricas}

A injeção de soluções poliméricas se mostrou econômica e tecnologicamente viável em vários projetos de Recuperação Avançada de Petróleo, pois é um método cujos custos de implementação e operação são relativamente baixos, comparado com outros métodos de recuperação avançada.

Soluções poliméricas são utilizadas em muitos casos como uma forma de aumentar a viscosidade da água e consequentemente reduzir a razão de mobilidade entre a água e o óleo. Desta forma, a injeção de soluções poliméricas torna a frente de deslocamento de óleo mais uniforme, melhorando a eficiência de varrido do meio poroso (Fig. 3).
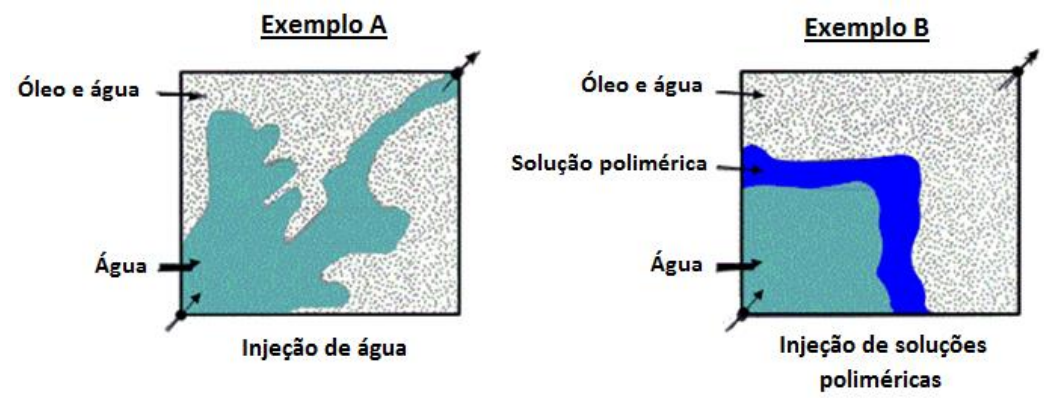

Figura 3 - Comparação entre a injeção de água e a injeção de soluções poliméricas (GREEN; WILLHITE, 1998) 
As dificuldades no deslocamento de óleo no interior do meio poroso são maiores em reservatórios de óleo pesado (baixo grau API), pois as longas cadeias de carbono implicam em viscosidades mais elevadas, a adição de polímeros à água de injeção é então empregada com o objetivo de maximizar a recuperação de óleo.

$\mathrm{Na}$ literatura, diversos estudos foram realizados com o objetivo de entender a injeção de soluções poliméricas e seu comportamento no interior do reservatório.

Sandiford (1964) estudou a adição da poliacrilamida parcialmente hidrolisada na água de injeção com o objetivo de aumentar sua viscosidade e consequentemente a recuperação de óleo. Realizou também testes em campo e percebeu a possibilidade de aplicação comercial da poliacrilamida como método de recuperação.

Smith (1970) analisou o comportamento de soluções poliméricas escoando em meios porosos. Foram estudados os efeitos de adsorção; relação da redução da mobilidade com a salinidade, peso molecular e aumento da taxa de injeção; degradação mecânica e temperatura.

Os benefícios da injeção de soluções poliméricas vão além do simples aumento da viscosidade da água. Soluções poliméricas de alto peso molecular podem apresentar um comportamento viscoelástico, que pode ter um alto impacto no processo de deslocamento de óleo pela fase aquosa, tanto na escala macroscópica como na escala de poros.

Em 1992, Ranjbar e colaboradores realizaram experimentos em amostras naturais e artificiais e perceberam uma taxa de injeção crítica acima da qual era possível observar efeitos viscoelásticos.

Wang (1994) observou efeitos viscoelásticos em soluções poliméricas no escoamento em meios porosos. Este comportamento é fortemente dependente da taxa de deformação sofrida pelo fluido no espaço poroso.

Wang e colaboradores (2000) realizaram estudos que correlacionam o aumento da recuperação de óleo em escala microscópica a elasticidade das soluções poliméricas. Foram feitos testes em laboratório com fluidos newtonianos (água e glicerina) e soluções poliméricas (poliacrilamida parcialmente hidrolisada). Eles observaram a redução do volume de óleo preso com a injeção de soluções poliméricas viscoelásticas, conforme apresentado na Figura 4. 


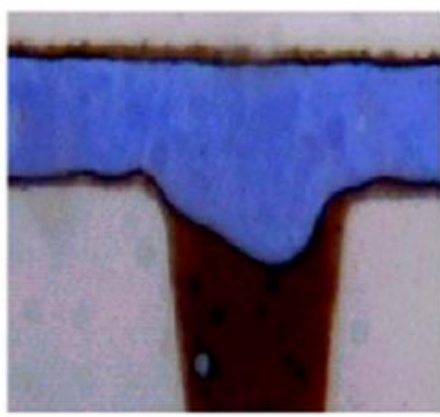

Após injeção de água

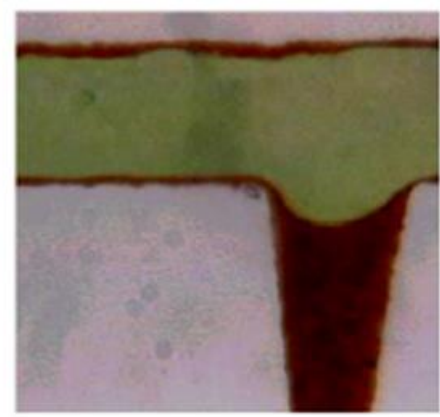

Após injeção de glicerina

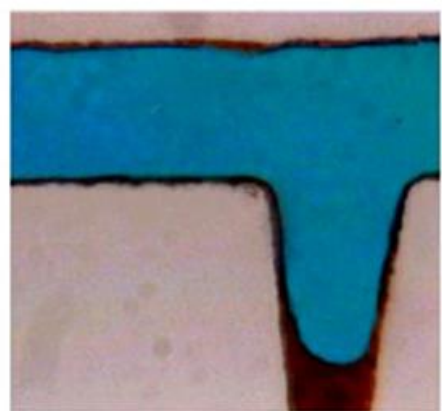

Após injeção de solução polimérica

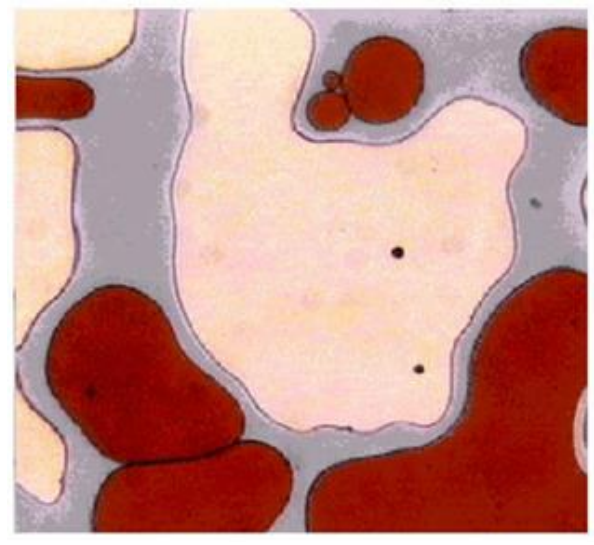

Após injeção de água

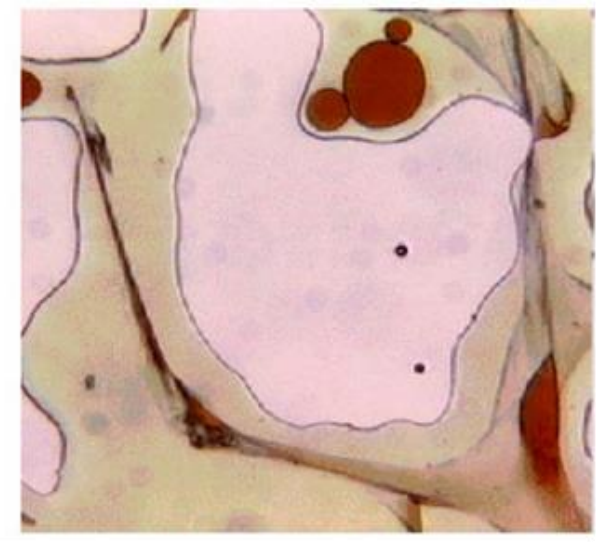

Após injeção de solução polimérica

Figura 4 - Resultados obtidos por Wang e outros (2000)

De acordo com Wei e colaboradores (2013), o produto das eficiências de deslocamento macroscópica e microscópica define a eficiência total de deslocamento durante o processo de recuperação de óleo. A eficiência de deslocamento macroscópica é a medida da efetividade do fluido deslocante considerando o reservatório como um todo, e a eficiência microscópica refere-se à efetividade do fluido deslocante para mobilizar o óleo preso por forças capilares.

Após uma região do reservatório ser varrida pela fase aquosa, um determinado volume de óleo fica retido nos poros por forças capilares, representando a saturação residual de óleo (Sor). Um gânglio de óleo retido pode ser mobilizado caso a diferença de pressão nas extremidades do gânglio definida pelo escoamento da fase aquosa, seja maior do que a pressão capilar, conforme esquematizado na Figura 5. 

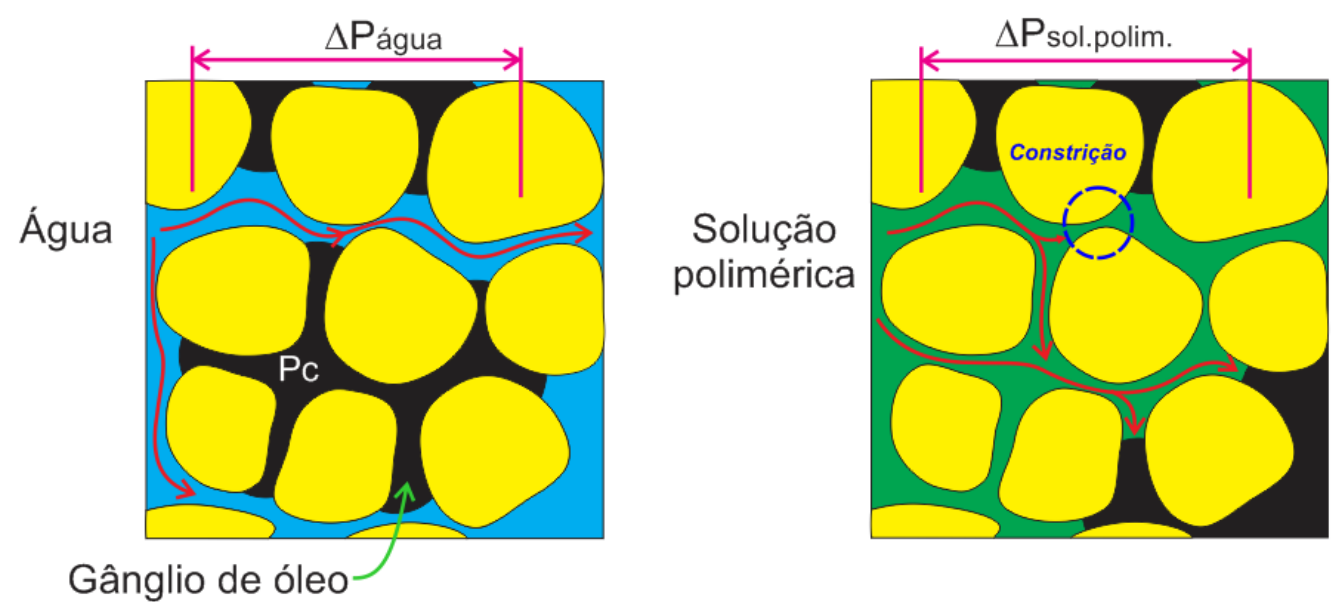

Figura 5 - Solução polimérica deslocando gânglio de óleo

Estudos têm mostrado que o comportamento elástico de soluções poliméricas pode, além de diminuir a razão de mobilidade, contribuir para um melhor deslocamento de óleo em escala de poro, aumentando a queda de pressão da fase aquosa no escoamento através de gargantas de poros e, consequentemente mobilizando gânglios de óleo e reduzindo a saturação de óleo residual (AFSHARPOOR et al., 2012). Nesse trabalho, micromodelos 2-D em vidro serão utilizados para melhor entender este comportamento.

\section{Micromodelos e sua utilização em escoamento em meios porosos}

A visualização do escoamento na escala de poro foi bastante desenvolvida após o amadurecimento das tecnologias de fabricação de microcanais e microdispositivos. Redes de microcanais são usadas como modelos transparentes de meios porosos para estudar fenômenos na escala de poros.

Berejnov e colaboradores (2008) representaram o meio poroso como uma rede estruturada de microcanais feita de PDMS (Polidimetilsiloxano) com aproximadamente 5 mil canais. Em seus experimentos, eles investigaram o efeito das propriedades dos fluidos e da molhabilidade das paredes no processo de saturação por um líquido de um meio inicialmente saturado por ar. Os resultados mostram os padrões irregulares da frente de avanço do líquido (Fig. 6). 

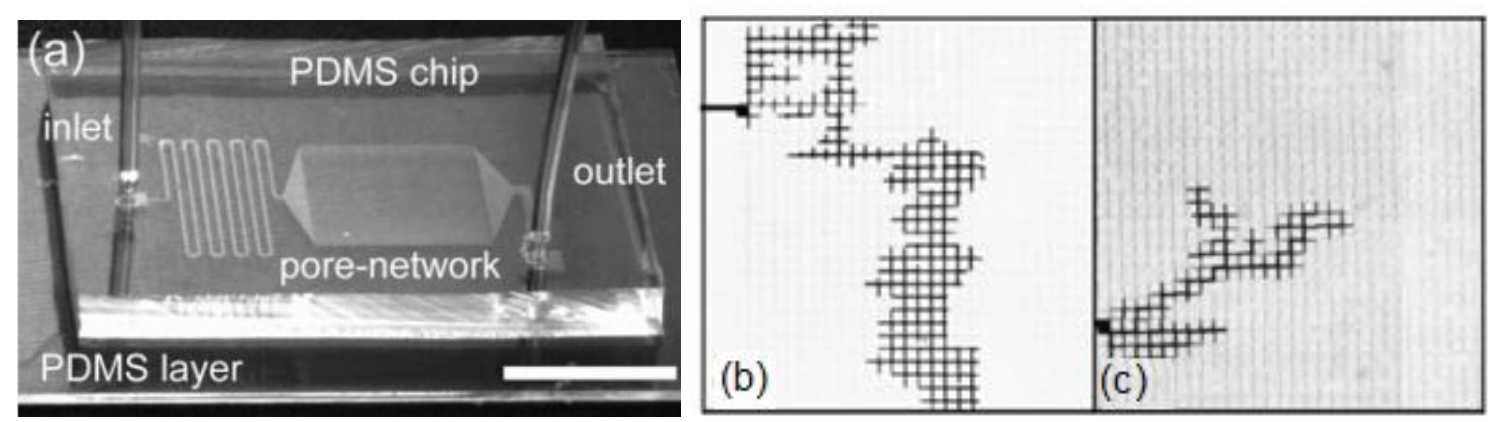

Figura 6 - Micromodelo utilizado por Berejnov et al (2008) (a) e alguns resultados obtidos experimentalmente (pode-se observar a frente de avanço em um meio poroso regular (b) e irregular (c) totalmente saturado de ar)

Buchgraber e colaboradores (2009) realizaram experimentos com o objetivo de estudar o deslocamento de óleo viscoso através da injeção de soluções poliméricas com micromodelos 2D feitos de silício e vidro (Fig. 7). Analisaram a formação de viscous fingering e a eficiência de recuperação.
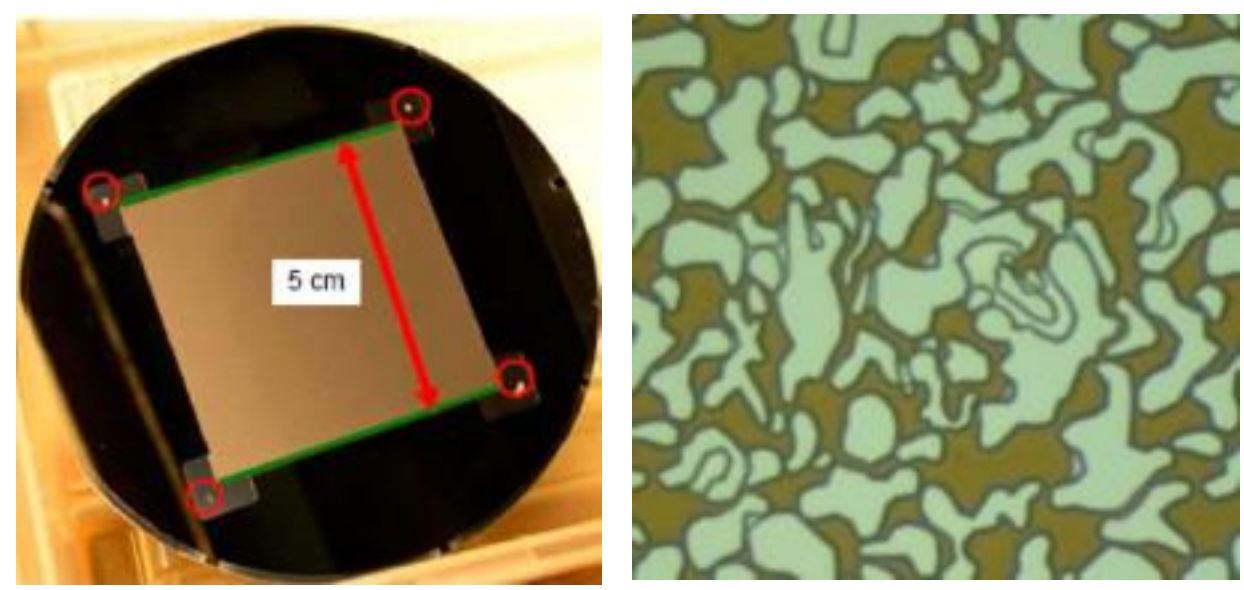

Figura 7 - Dispositivo utilizado por Buchgraber et al (2009) e imagem microscópica do meio poroso

Foram realizados testes comparativos utilizando solução salina e diferentes tipos de soluções poliméricas. Percebeu-se que a eficiência de varrido era maior quando o polímero era adicionado, como pode ser observado na Figura 8. 


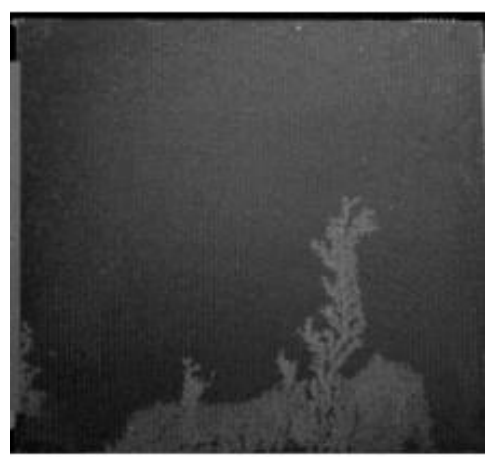

$50 \mathrm{~min}$.

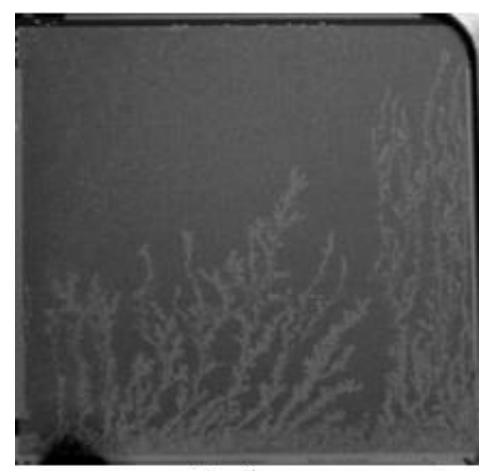

$51 \mathrm{~min}$

Figura 8 - Resultados obtidos com solução salina (esquerda) e com solução polimérica (direta) (BUCHGRABER et al., 2009)

Em 2011, Kumar Gunda e colaboradores desenvolveram um dispositivo de microfluídica 2D, com 2 mil poros e 6 mil gargantas, feito em silício e vidro, cuja geometria foi baseada em rochas-reservatório reais como apresentado na Figura 9. A visualização do fluxo permitiu avaliar a presença de óleo preso e o deslocamento das fases no meio. Foram realizados testes de injeção de água, com óleo tingido na cor verde e água na cor azul. Visualização do espaço poroso, como apresentado na Figura 10, permitiu a determinação do volume de óleo deslocado.

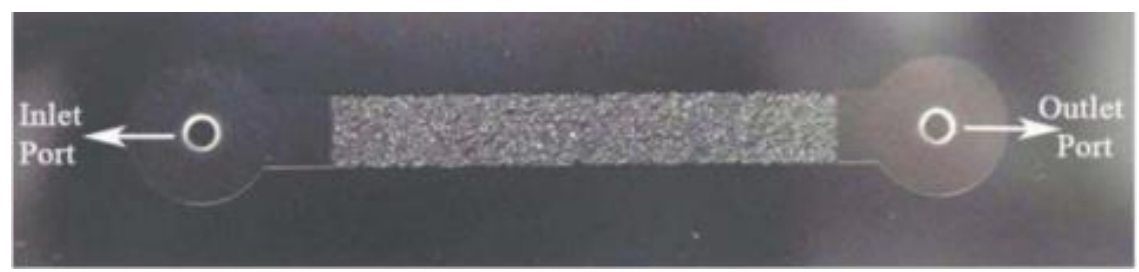

Figura 9 - Micromodelo utilizado por Kumar Gunda et al (2011)
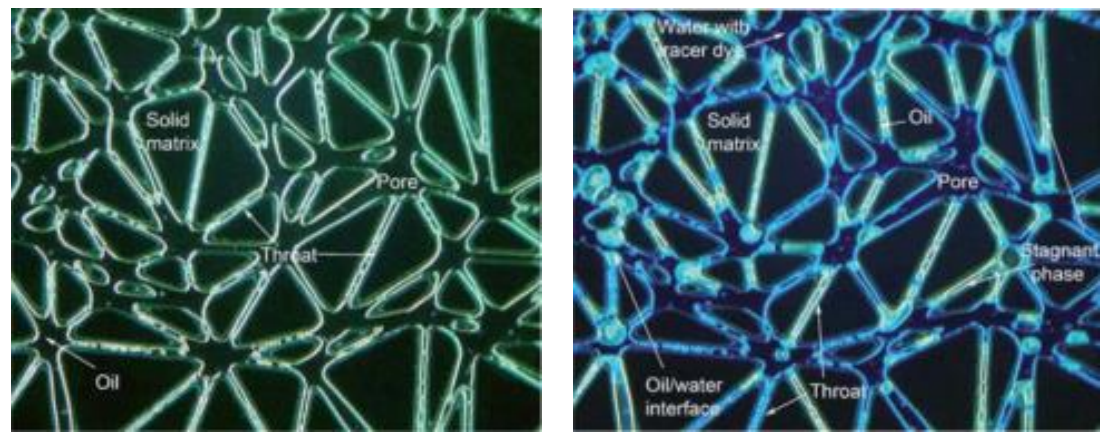

Figura 10 - Distribuição dos fluidos no meio poroso antes e após a injeção de água (KUMAR GUNDA et al., 2011) 
O efeito da reologia dos fluidos na recuperação avançada de óleo com a utilização de dispositivos microfluídicos (Fig. 11) foi estudado por Nilsson e colaboradores (2013) a partir de micromodelos de PDMS. Foram traçadas curvas de saturação de óleo residual como função do número de capilaridade para os diferentes fluidos injetados (água, surfactante e fluidos não-newtonianos). Os melhores resultados encontrados foram para a solução de PEO 0,4\% com nanopartículas, seguidos da solução de PEO de baixo peso molecular, Flopaam 3630 , soluções de surfactante e água pura. Percebeu-se também que não existia muita diferença na recuperação de óleo injetando água seguida de um fluido secundário ou somente o fluido secundário desde o início.
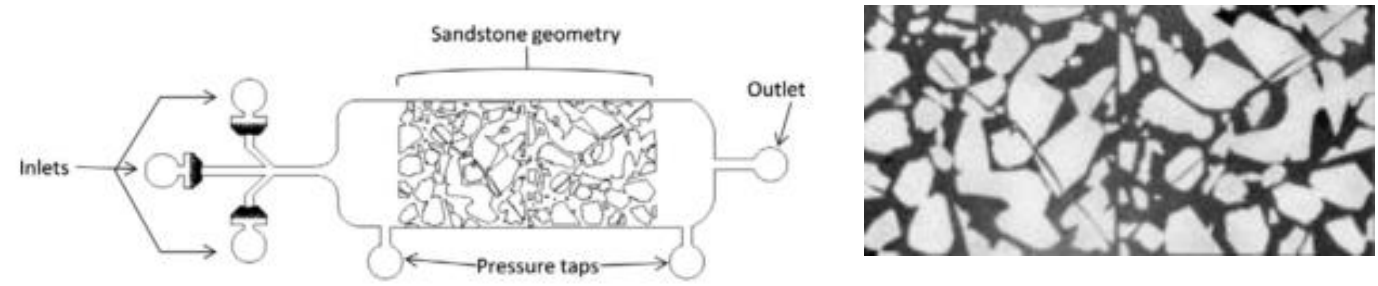

Figura 11 - Meio poroso utilizado por Nilsson e colaboradores (2013) e a geometria observada no microscópio

\section{2.}

\section{Objetivos do trabalho}

Apesar dos avanços recentes, o efeito de propriedades viscoelásticas de soluções poliméricas no deslocamento de óleo na escala de poros ainda não é bem entendido.

O efeito do comportamento viscoelástico na mobilização de gânglios de óleo na escala de poros não foi estudada de forma sistemática e controlada.

O presente trabalho tem como objetivo a análise do deslocamento de óleo por soluções poliméricas em meios porosos em escala microscópica, utilizando micromodelos fabricados em vidro.

Para entender o efeito da viscoelasticidade das soluções poliméricas na redução da saturação de óleo residual foram realizados experimentos de injeção de fluidos newtonianos (água e água com glicerina) e soluções de poli(óxido de etileno) e medidas as saturações de óleo residual através do processamento de imagens obtidas. 


\section{2}

\section{Abordagem experimental}

\section{1.}

\section{Bancada experimental}

A bancada experimental utilizada para o desenvolvimento desse trabalho foi montada com o objetivo de estudar o comportamento de soluções poliméricas quando utilizadas para deslocar óleo no interior de um meio poroso e estimar a saturação de óleo residual por meio do processamento de imagens (Figuras $12 \mathrm{e}$ 13).

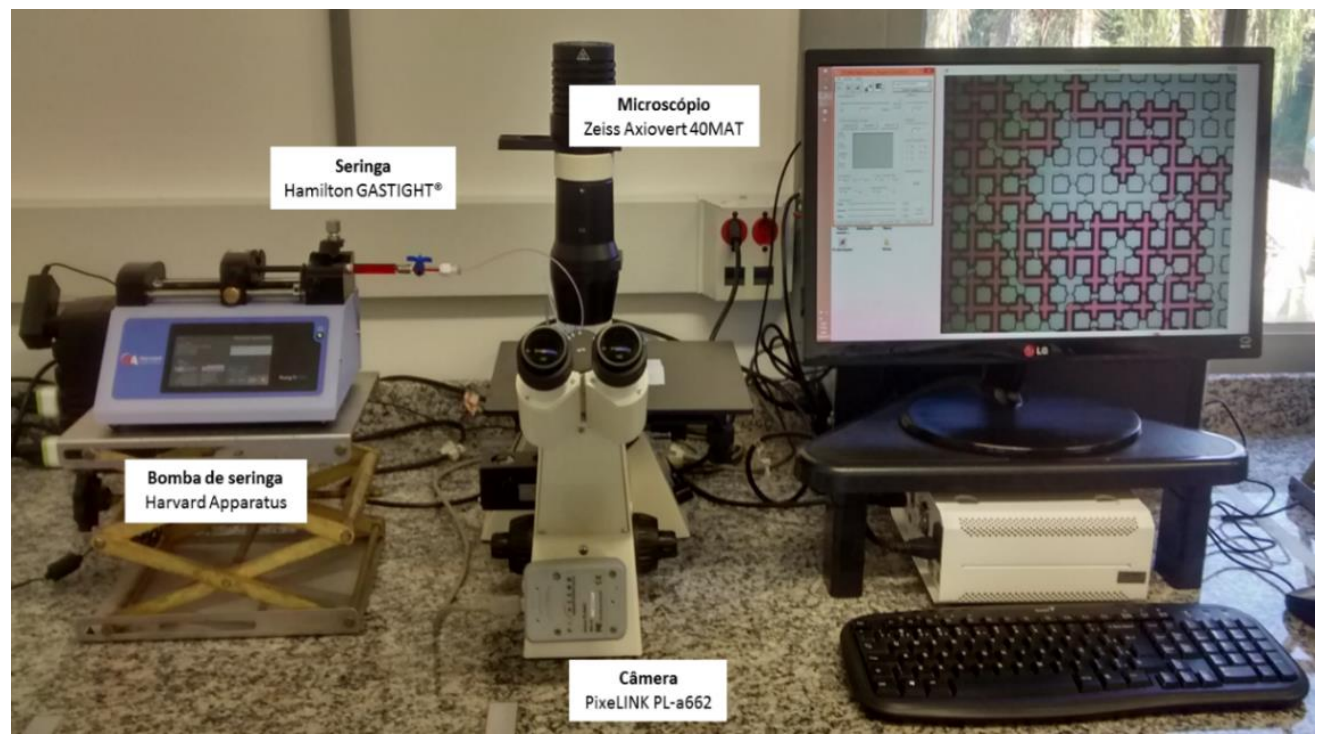

Figura 12 - Bancada experimental

O dispositivo experimental consiste basicamente de:

1. Micromodelo de vidro: Representação artificial de um meio poroso, formado por poros e gargantas interconectados.

2. Sistema de injeção de fluidos: Consiste de bombas de seringa e seringas contendo os fluidos a serem injetados.

3. Sistema de visualização do fluxo através do meio poroso, composto por um microscópio invertido e uma câmera.

4. Sistema para processamento de imagens: Computador com o programa desenvolvido em MATLAB para processar as imagens. 

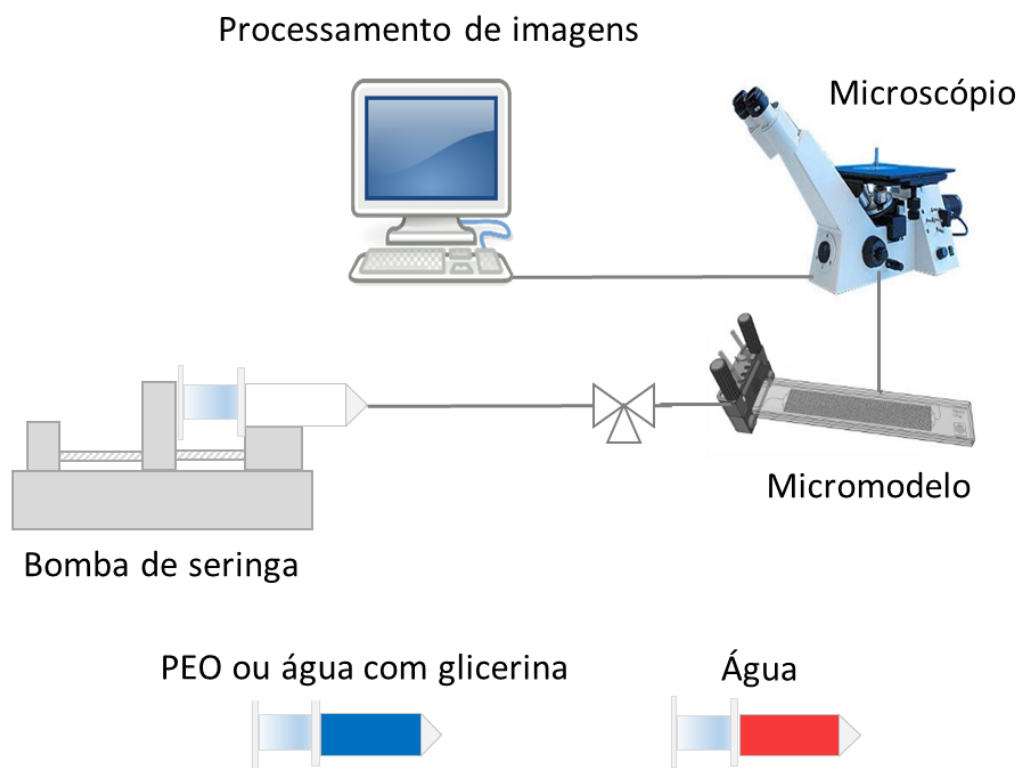

Figura 13 - Esquema da banca experimental

\subsection{1. \\ Micromodelo de vidro}

Com o objetivo de analisar o deslocamento de óleo através da injeção de soluções poliméricas em escala de poro, foi utilizado um dispositivo de microfluídica que reproduz artificialmente um meio poroso. O dispositivo é composto de microcanais interconectados com constrições de diferentes tamanhos que simulam as gargantas de poros em um meio poroso. A Figura 14 apresenta uma foto do dispositivo.

O micromodelo utilizado é comercializado pela Dolomite Microfluidics, feito em vidro, gravado com ácido fluorídrico (HF) e colado através de um tratamento térmico. Dentre as vantagens para a sua utilização estão a ampla faixa de temperatura e pressão de trabalho, excelente compatibilidade química, alta visibilidade (ideal para utilização em microscópio) e a rigidez do meio, evitando as deformações dos canais que ocorrem nos dispositivos em PDMS, geralmente utilizados neste tipo de estudo.

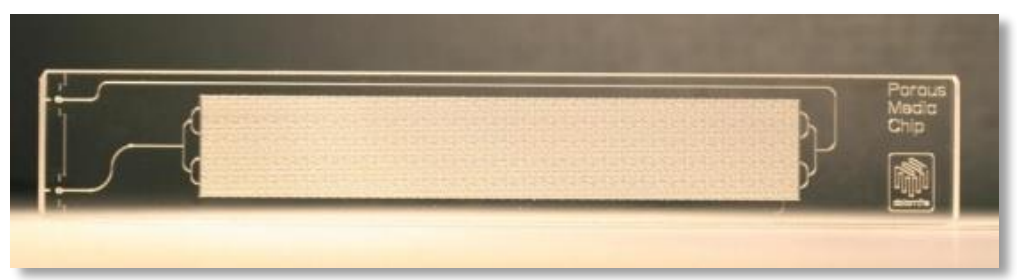

Figura 14 - Micromodelo de vidro 
A geometria do microdispositivo é formada por uma rede de canais com seção reta quase circular (altura do canal $=100 \mu \mathrm{m}$ e largura do canal $=110 \mu \mathrm{m}$ ) que reproduz artificialmente um meio poroso. A área porosa do chip tem um desenho de $10 \times 60 \mathrm{~mm}$ e dois orifícios simétricos, um para entrada e outro para saída. Para garantir uma distribuição uniforme do fluxo, a entrada e a saída se bifurcam duas vezes, resultando em quatro pontos de entrada e quatro pontos de saída (Fig. 15). Além disto, um canal com $250 \mu \mathrm{m}$ de largura conecta todos os canais da entrada e saída, contribuindo assim para uma uniformização da pressão de entrada e saída.
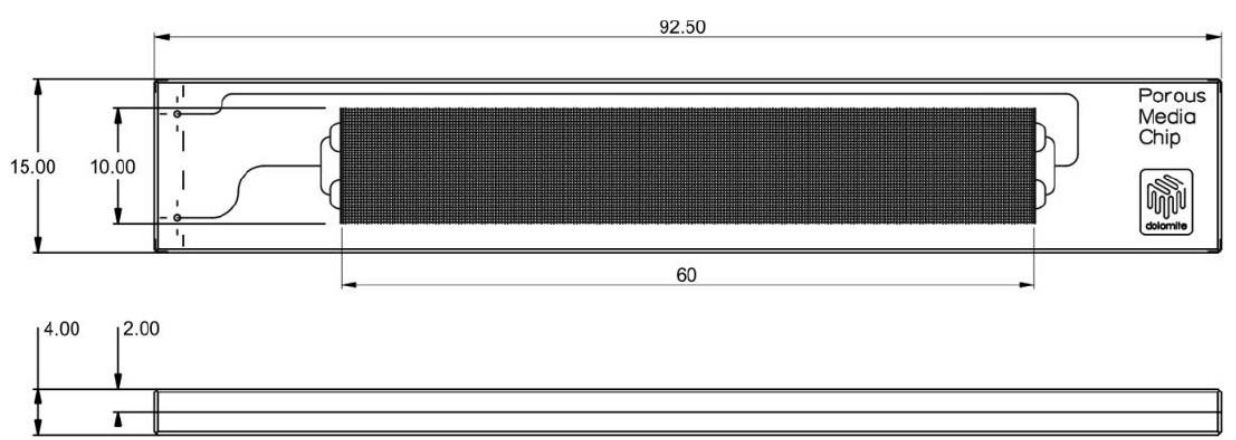

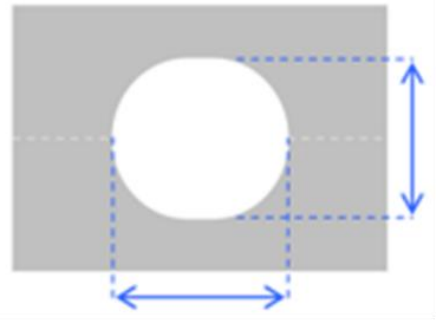

Altura do canal $=100 \mu \mathrm{m}$ $=110 \mu \mathrm{m}$

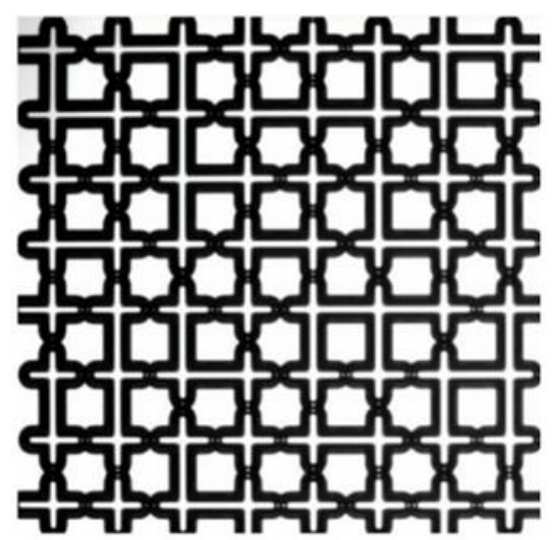

Figura 15 - Dimensões do micromodelo, dimensões do canal e vista macroscópica do meio poroso

Os canais têm diferentes tamanhos de gargantas, com o objetivo de reproduzir a heterogeneidade dos tamanhos de gargantas de poros de um meio poroso natural. As constrições são randomicamente distribuídas no dispositivo. $\mathrm{O}$ micromodelo possui 38 constrições de $63 \mu \mathrm{m}, 40$ constrições de $85 \mu \mathrm{m}$ e 50 canais de $110 \mu \mathrm{m}$. O padrão é constituído de uma malha $(8 \times 8)$ que se repete periodicamente, no total 150 vezes, como descrito na Figura 16. 
Grid 8x8

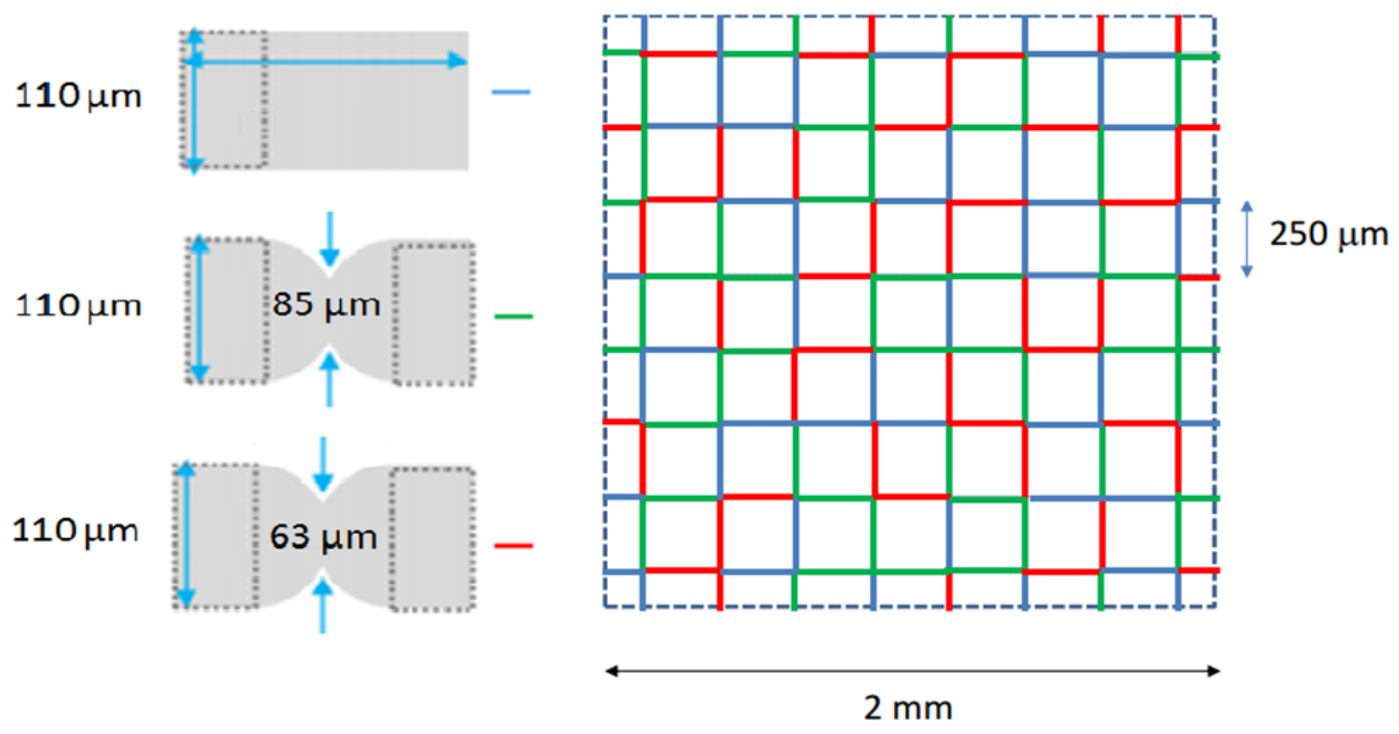

Figura 16 - Constrições e arranjo dos canais

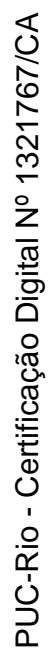

O micromodelo utiliza um conector específico, comercializado pela Dolomite Microfluidics, o Multiflux ${ }^{T M}$ 4-way linear connector, mostrado na Figura 17. $\mathrm{Na}$ montagem experimental, o micromodelo é utilizado na horizontal, o que anula possíveis efeitos gravitacionais.

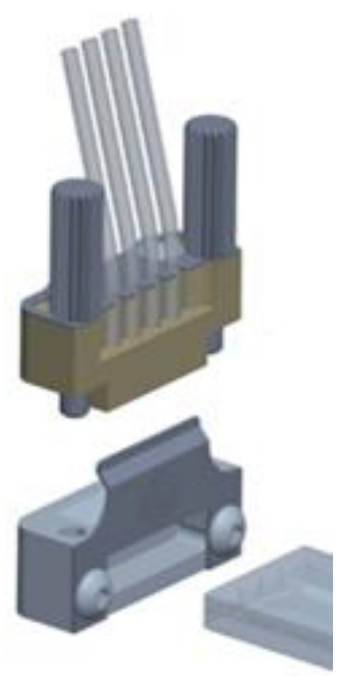

Figura 17 - Multiflux ${ }^{T M}$ 4-way linear connector

Outras propriedades do micromodelo são apresentadas na Tabela 1: 
Tabela 1 - Propriedades gerais do micromodelo

\begin{tabular}{cc}
\hline Parâmetro & Micromodelo \\
\hline Número de entradas & 1 \\
Número de saídas & 1 \\
Comprimento do canal de entrada & $27,7 \mathrm{~mm}$ \\
(incluindo bifurcações) & \\
Comprimento da saída & $99,2 \mathrm{~mm}$ \\
Volume do canal de entrada & $0,9 \mu \mathrm{l}$ \\
Volume do canal de saída & $3,2 \mu \mathrm{l}$ \\
Rugosidade & $5 \mathrm{~nm}$ \\
Dimensões do chip & $92,5 \mathrm{~mm} \times 15,0 \mathrm{~mm}$ \\
Pressão de operação & $30 \mathrm{bar}$
\end{tabular}

Vargas (2014) calculou o volume poroso do microchip experimentalmente através da razão entre o volume poroso e o volume total do micromodelo. Utilizando uma balança eletrônica pesou o meio poroso saturado com ar, isto é, seu peso seco. Posteriormente saturou o microchip com água destilada e pesou novamente. Subtraindo o peso úmido do peso seco é possível estimar o volume ocupado pelo fluido no dispositivo, isto é, seu volume poroso. O valor encontrado foi de 30 microlitros. E a porosidade é de aproximadamente $50 \%$.

A permeabilidade foi estimada utilizando um modelo de rede por Bartolomeu e Carvalho (2015) e o valor encontrado para o micromodelo foi de 79D.

\subsection{2.}

\section{Sistema de injeção de fluidos}

O sistema consiste de bombas de infusão de seringa única, modelo Harvard Apparatus Elite 11, utilizadas para injetar diferentes fluidos no micromodelo (Fig. 18).

Todos os experimentos foram realizados utilizando seringas Hamilton Gastigh® da série 1000. As seringas são feitas em vidro e tem embolo metálico com terminação em Teflon, que garantem estabilidade e não permitem vazamentos, mesmo em altas pressões, e conexões do tipo Luer Lock que facilitaram a montagem do sistema. 


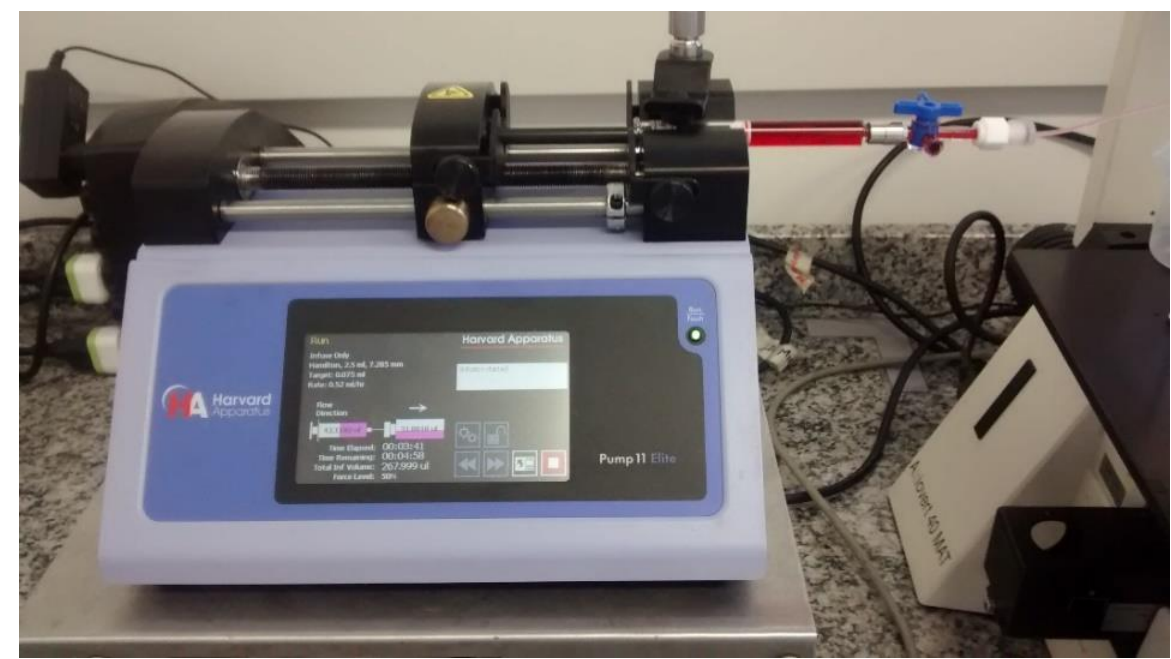

\section{Figura 18 - Bombas de seringa Harvard Apparatus e seringas Hamilton}

Válvulas de três vias SOLIDOR foram utilizadas para conectar a seringa ao micromodelo e controlar o fluxo, mangueiras de diâmetro interno 1/32" e conectores especiais para dispositivos de microcanais completam o sistema (Fig. $19)$.

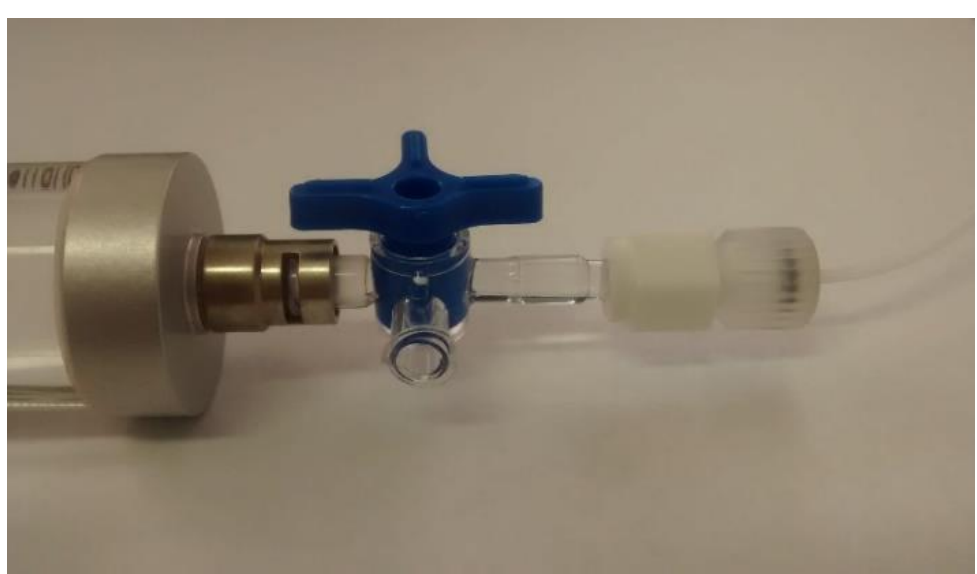

Figura 19 - Válvula SOLIDOR, conector e mangueira 


\subsection{3.}

\section{Sistema de visualização do fluxo através do meio poroso}

Para a visualização do escoamento no meio poroso, foi utilizado um microscópio óptico invertido Carl Zeiss, modelo Axiovert 40MAT com iluminação na parte superior (Fig. 20). O microscópio possui cinco objetivas (2.5X, 5X, 10X, 20X e 50X), para esse trabalho foi utilizada a objetiva de $2.5 \mathrm{X}$.
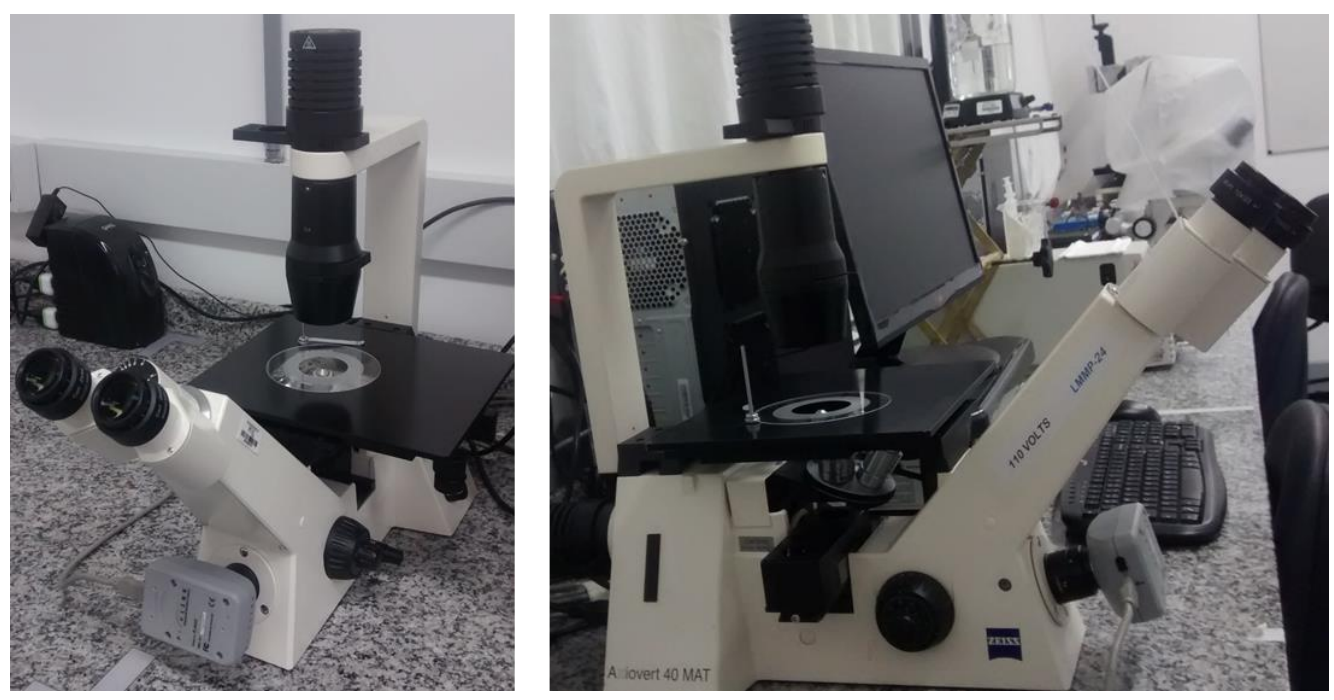

Figura 20 - Microscópio Carl Zeiss modelo Axiovert 40MAT

A aquisição das imagens e vídeos dos fluidos no meio poroso foi possível com a utilização de uma câmera PixeLINK (PL-A662) com 1.3 megapixels de resolução (1280 x 1024) conectada ao computador através do software PixeLINK Application, que transmite em tempo real permitindo a visualização no monitor (Fig. 21).
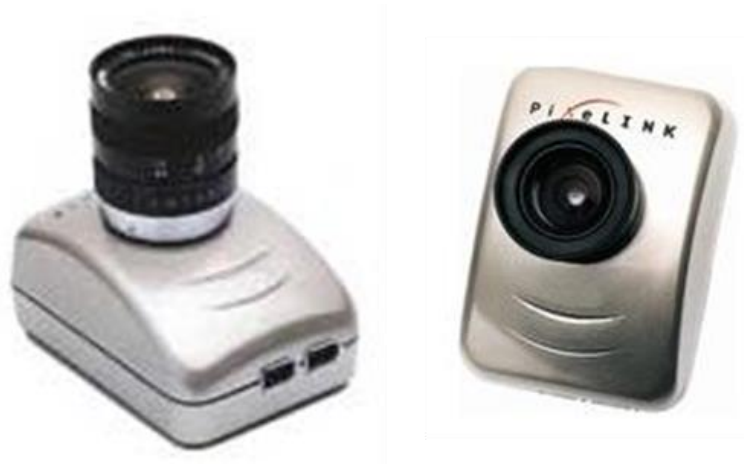

Figura 21 - Câmera PixeLINK PL-a662 


\subsection{4.}

\section{Sistema para processamento de imagens}

O sistema utilizado para o processamento das imagens consiste de um computador com o software desenvolvido em MATLAB, para o tratamento das imagens obtidas e determinação da saturação das fases. $O$ código foi desenvolvido por Fábio Jessen W. de A. Martins e Paula Stofer C. de F. Bormann, do Laboratório de Engenharia de Fluidos, do DEM da PUC-Rio.

\section{2.}

\section{Materiais}

No presente trabalho foram utilizados os seguintes fluidos de trabalho: óleo mineral (Drakeol@ 7 - Agecom), soluções de poli(óxido de etileno), água deionizada e misturas de água com glicerina. Para diferenciar os fluidos na visualização no microscópio corantes azul e vermelho foram utilizados.

\subsection{1.}

Óleo

O Drakeol® 7 é um óleo mineral branco de base parafínica com baixa viscosidade e isento de carbonos aromáticos. Tem cor clara, é sem odor e não tóxico. Suas propriedades são apresentadas na Tabela 2, abaixo.

Tabela 2 - Propriedades do Drakeol® 7

\begin{tabular}{|c|c|c|c|c|c|}
\hline \multirow[t]{2}{*}{ Propriedade } & \multicolumn{5}{|c|}{ Temperatura $(\stackrel{\circ}{ } \mathrm{C})$} \\
\hline & 20 & 25 & 30 & 40 & 50 \\
\hline Viscosidade $(\mathrm{cP})$ & 22,20 & 17,78 & 14,50 & 10,02 & 7,27 \\
\hline Densidade $(\mathrm{g} / \mathrm{mL})$ & 0,8467 & 0,8446 & 0,8413 & 0,8338 & 0,8277 \\
\hline Tensão superficial (mN/m) & 27,8 & 28,3 & 28,6 & 28,4 & 28,6 \\
\hline
\end{tabular}




\subsection{2.}

\section{Solução polimérica}

O poli(óxido de etileno), conhecido também como PEO, é um polímero solúvel em água à temperatura ambiente, não tóxico, incolor, inodoro, límpido e inerte para muitos agentes químicos. É um homopolímero não iônico de óxido de etileno, isto é, composto por somente um tipo de monômero (SILVA, 2013), como ilustrado na Figura 22.

Amplamente empregado em inúmeras áreas do conhecimento, como odontologia, biologia, indústrias farmacêuticas e de materiais diversos, o PEO é um polímero artificial formado por adição. (GUITIÁN, 1994)
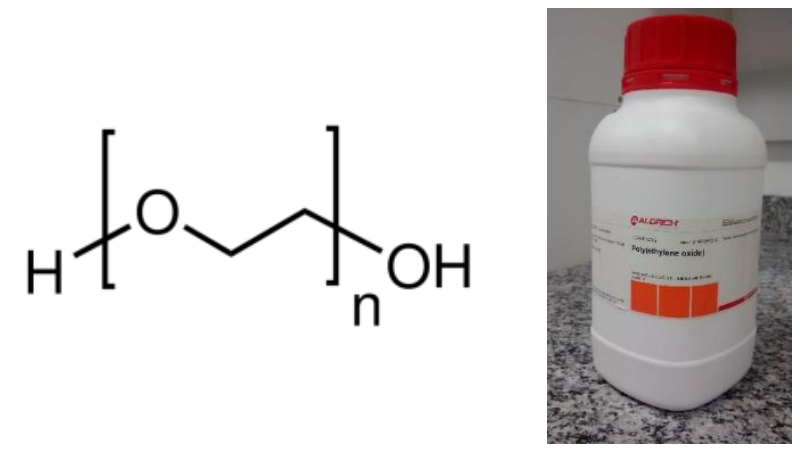

Figura 22 - Fórmula estrutural e polímero utilizado para os experimentos ( $M M=8,000,000 \mathrm{~g} / \mathrm{mol}$, produzido pela Sigma-Aldrich)

Para o preparo da solução, água deionizada e o polímero são pesados e posteriormente misturados utilizando o agitador mecânico IKA RW 20 Digital, como mostrado na Figura 23. Foi utilizado um corante alimentício na cor azul (Mix Coralim) para a solução polimérica, permitindo assim determinar a fração do espaço poroso ocupado pela solução polimérica. 

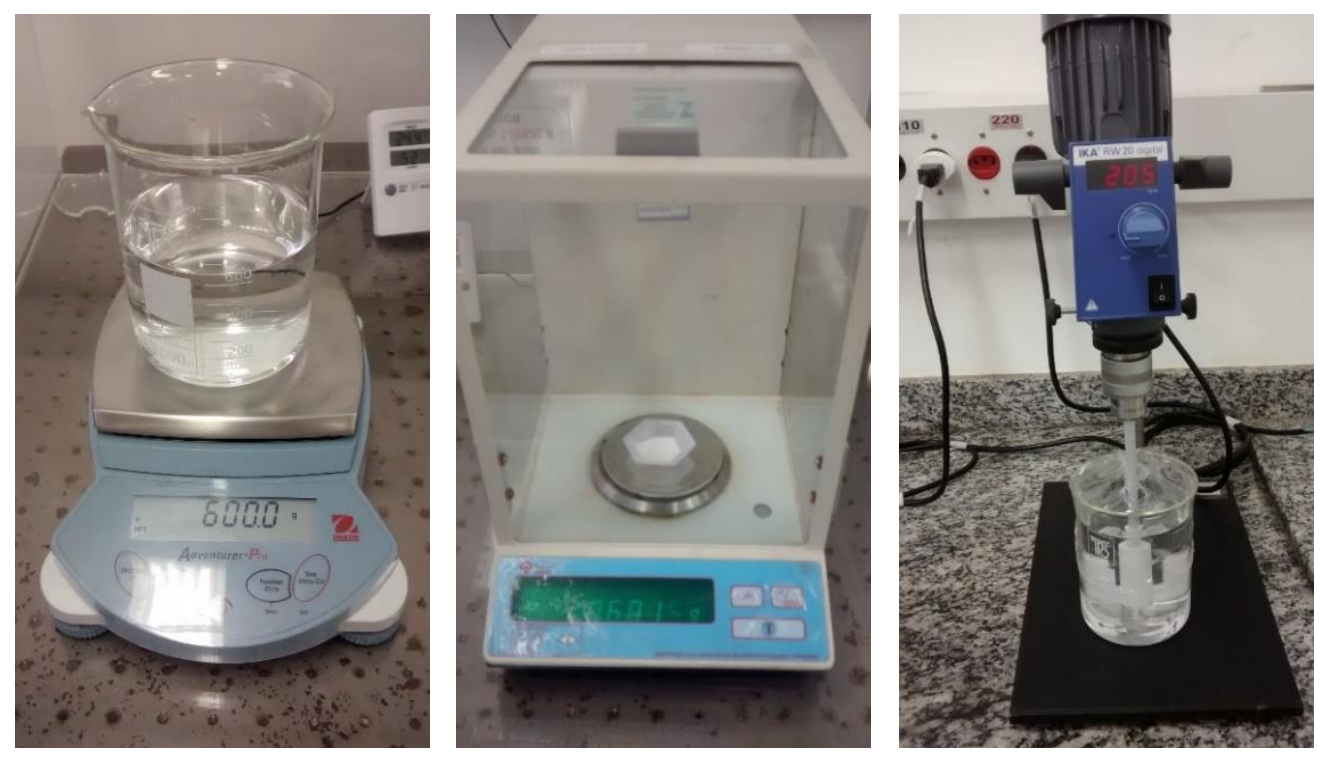

Figura 23 - Preparo da solução

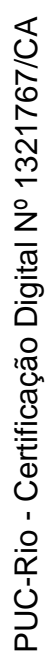

A densidade da solução polimérica foi determinada através da utilização de um picnômetro, pequeno frasco de vidro com volume constante (Fig. 24). As medidas foram feitas a uma temperatura de $24^{\circ} \mathrm{C}$. E o valor obtido foi de 1,058 para a solução de PEO com uma concentração de 0,1\% em peso.
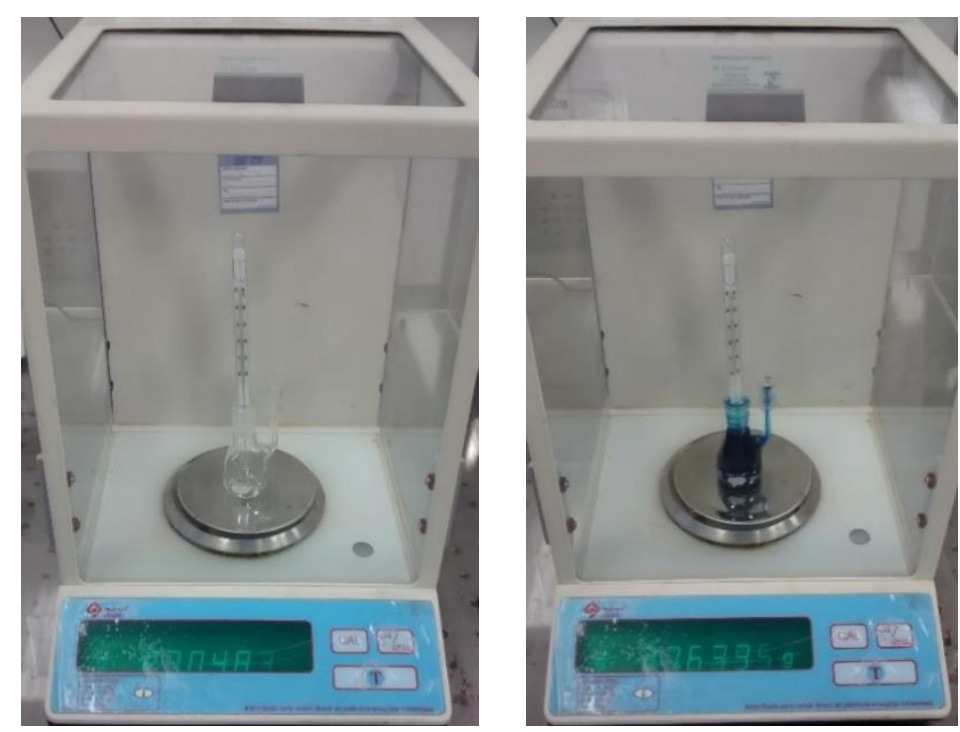

Figura 24 - Picnômetro

A tensão interfacial entre a solução polimérica e o óleo utilizado foi determinada usando um tensiômetro Tracker do fabricante TECLIS e o método da gota pendente. O sistema mostrado na Figura 25 é composto por: uma câmara 
experimental onde a gota é formada, cuja temperatura é controlada por um banho aquecido, um sistema óptico para iluminar e capturar a imagem da gota e um sistema de aquisição e processamento de imagem para calcular a tensão interfacial a partir da geometria da gota. $O$ valor encontrado para a tensão interfacial entre o PEO $0,1 \%$ e o óleo Drakeol ${ }^{\circledR} 7$ foi de $36,8 \mathrm{mN} / \mathrm{m}$ a $24^{\circ} \mathrm{C}$, utilizando uma gota com 30 microlitros de volume.
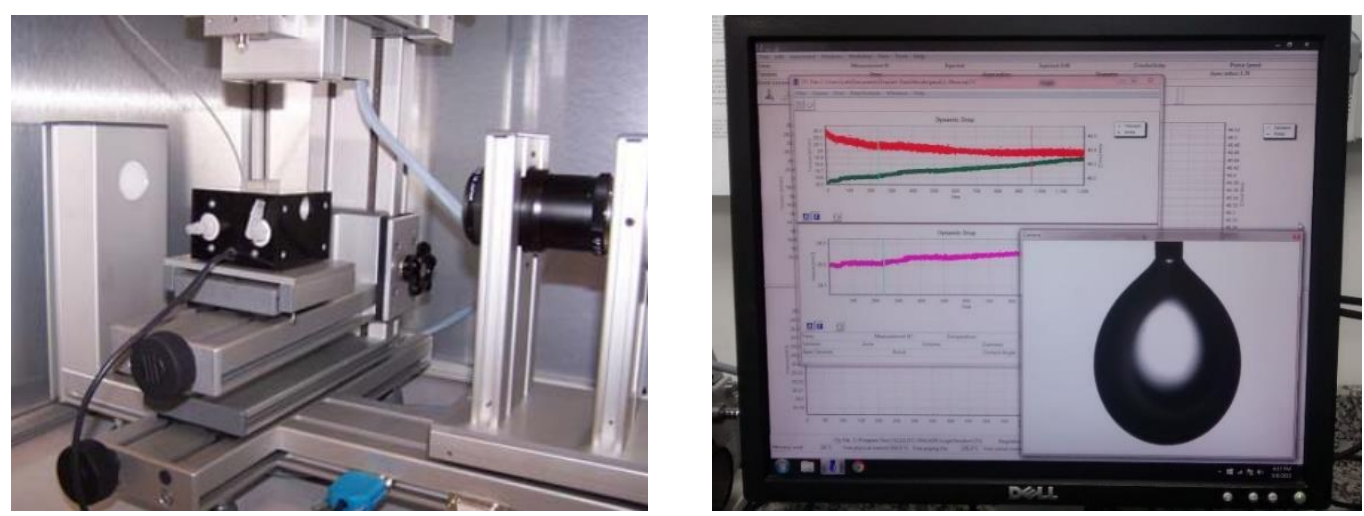

Figura 25 - Tensiômetro Tracker TECLIS

Os resultados obtidos são mostrados na Tabela 3, em todos os casos a fase deslocada é o óleo Drakeol® 7.

Tabela 3 - Tensão interfacial

\begin{tabular}{cc}
\hline Fluido deslocante & Tensão interfacial $(\mathbf{m N} / \mathbf{m})$ \\
\hline Água & 33,8 \\
Glicerina $51 \%$ & 33 \\
PEO $0,1 \%$ & 36,8 \\
\hline
\end{tabular}

Testes reológicos também foram realizados para determinar o comportamento mecânico das soluções poliméricas. Para cálculo da viscosidade de cisalhamento foi utilizado o reômetro rotacional Paar Physica MCR 501 (Fig. 26) e a geometria cone-placa de $6 \mathrm{~cm}$ - ângulo de 1丷, e foram obtidos dados para diferentes concentrações. 


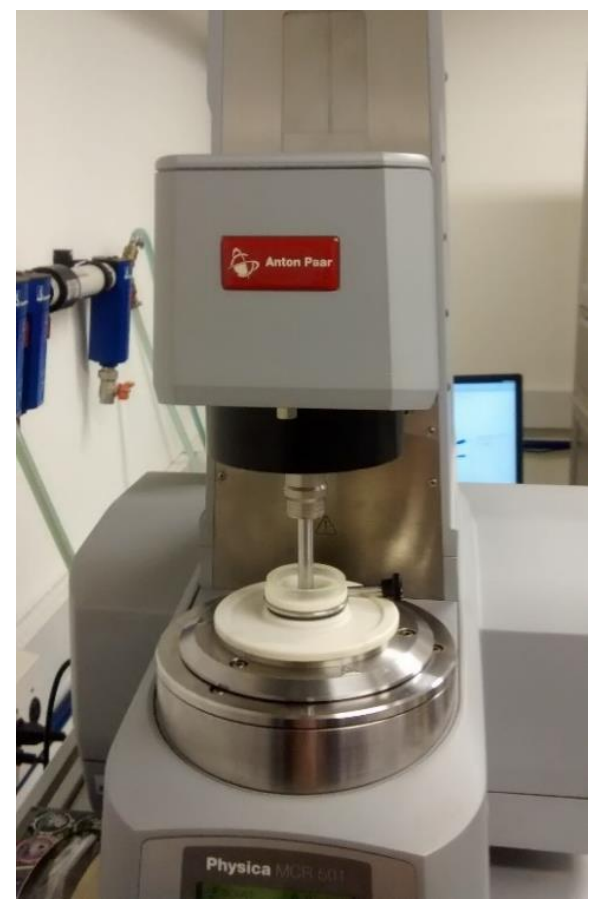

Figura 26 - Reômetro rotacional

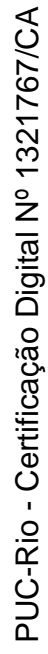

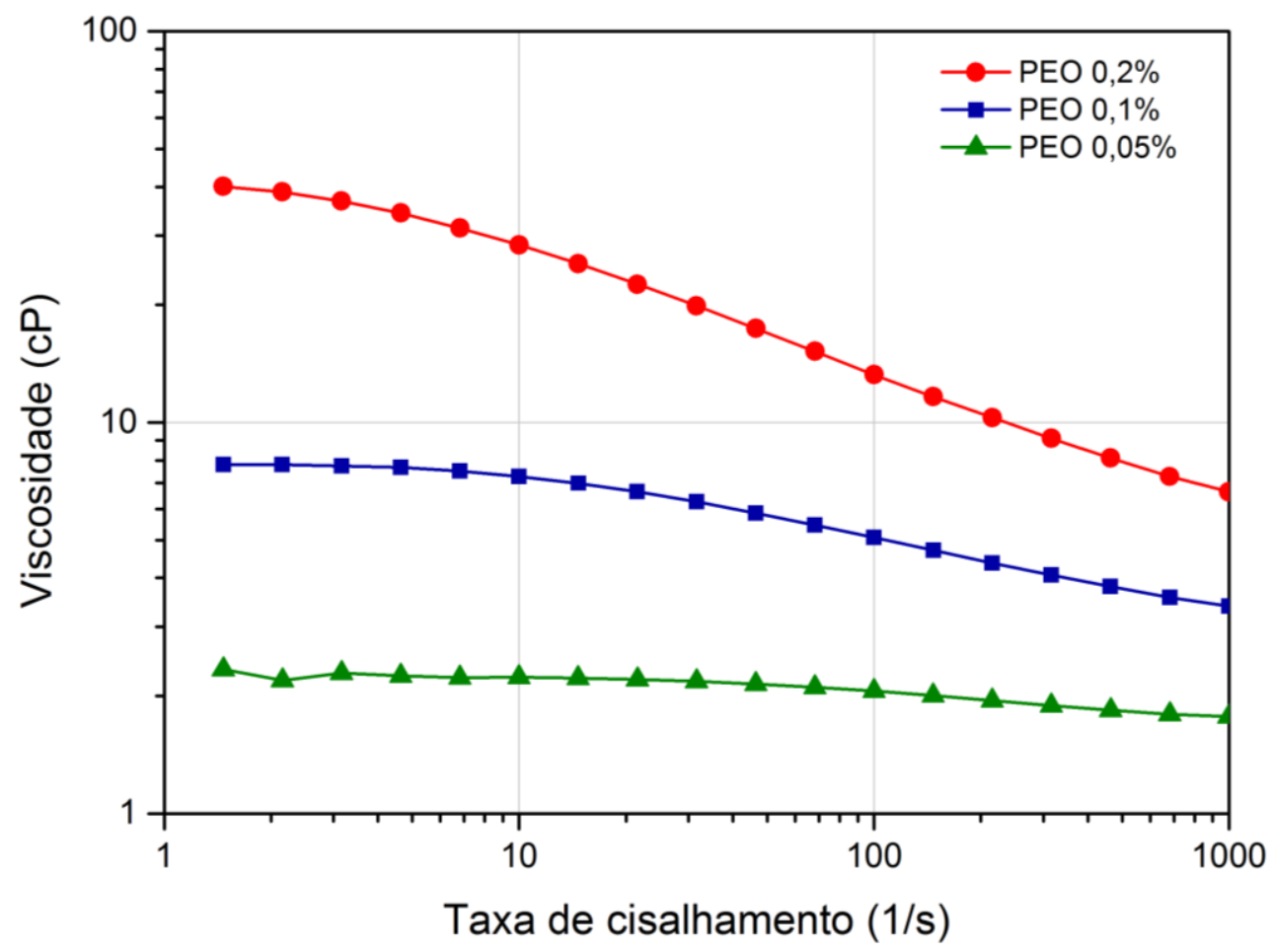

Figura 27 - Gráfico da viscosidade do PEO variando com a taxa de cisalhamento para diferentes concentrações 
A solução de PEO se comporta como um fluido de Boger para baixas concentrações $(0,05 \%)$, isto é, um fluido não-newtoniano viscoelástico, cuja viscosidade não varia com a taxa de cisalhamento. Para concentrações maiores $(0,1$ e $0,2 \%)$, a solução apresenta comportamento afinante (shear thinning) ou pseudoplástico. A viscosidade decresce com o aumento da taxa de cisalhamento, como indicado na Figura 27.

A viscosidade extensional aparente foi medida utilizando o reômetro extensional HAAKE CaBER (Thermo Fisher Scientific). O teste consiste na análise da quebra de filamentos. Uma gota do fluido é colocada entre duas hastes circulares. A inferior permanece fixa enquanto a superior é afastada rapidamente, formando um filamento de líquido. $O$ equipamento utiliza um laser para medir a espessura do filamento com o passar do tempo. A taxa de variação do diâmetro do filamento é relacionada com as propriedades do fluido (Fig. 28).

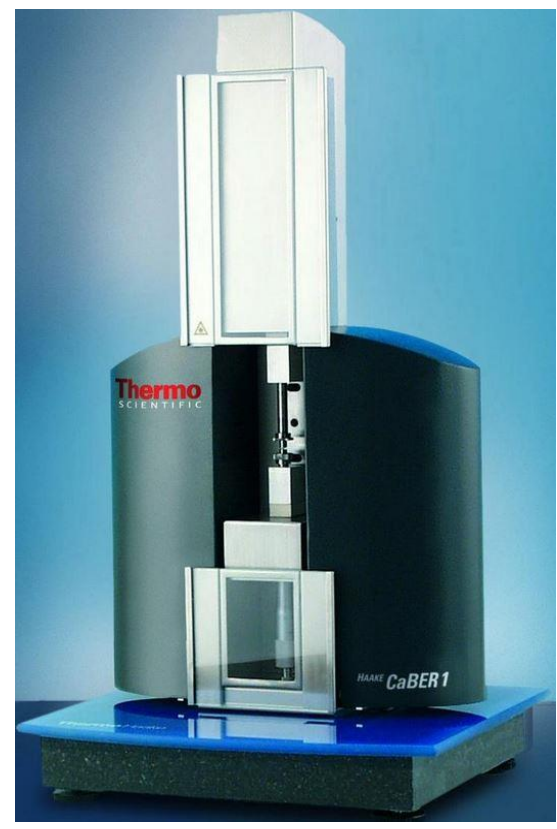

Fluido Newtoniano
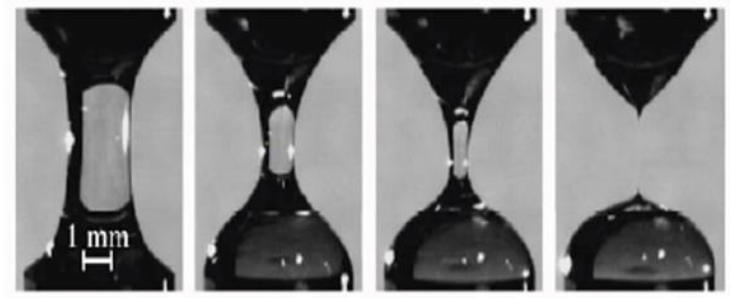

$t=0 \mathrm{~s}$

$t=4.2 \mathrm{~s}$

$t=6.3 \mathrm{~s}$

$t_{c r i t}=8.6 \mathrm{~s}$

Solução Polimérica
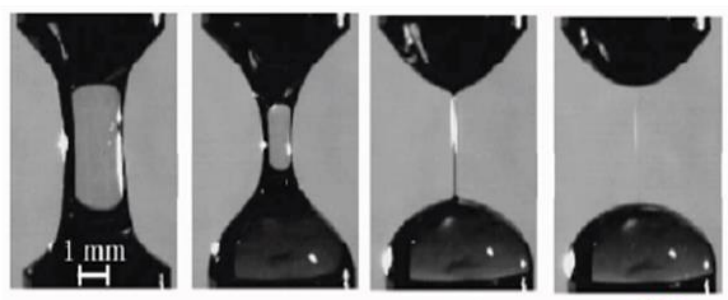

$t=0 \mathrm{~s}$

$t=8.5 \mathrm{~s}$

$l=25.5 \mathrm{~s}$

$t_{\text {rrit }}=42.5 \mathrm{~s}$

Figura 28 - Reômetro Haake CaBER e comportamento de fluidos submetidos a extensão

Os dados da variação do diâmetro com o tempo podem ser utilizados para avaliar a viscosidade extensional aparente, através da seguinte expressão:

$$
\bar{\eta}_{a p p}(\dot{\varepsilon})=-\frac{\sigma}{d D / d t} \quad \dot{\varepsilon}=-\frac{2}{D} \frac{d D}{d t} t
$$


onde:

$\dot{\varepsilon}$ é a taxa de deformação normal

$\bar{\eta}_{\text {app }}$ é a viscosidade extensional aparente

$\sigma$ é a tensão interfacial

$d D / d t$ é a variação do diâmetro com o tempo

$D$ é o diâmetro da seção média do filamento

$t$ é o tempo

A Figura 29 apresenta a viscosidade extensional aparente em função da taxa de deformação extensional. Observa-se o aumento da viscosidade extensional com a taxa de deformação.

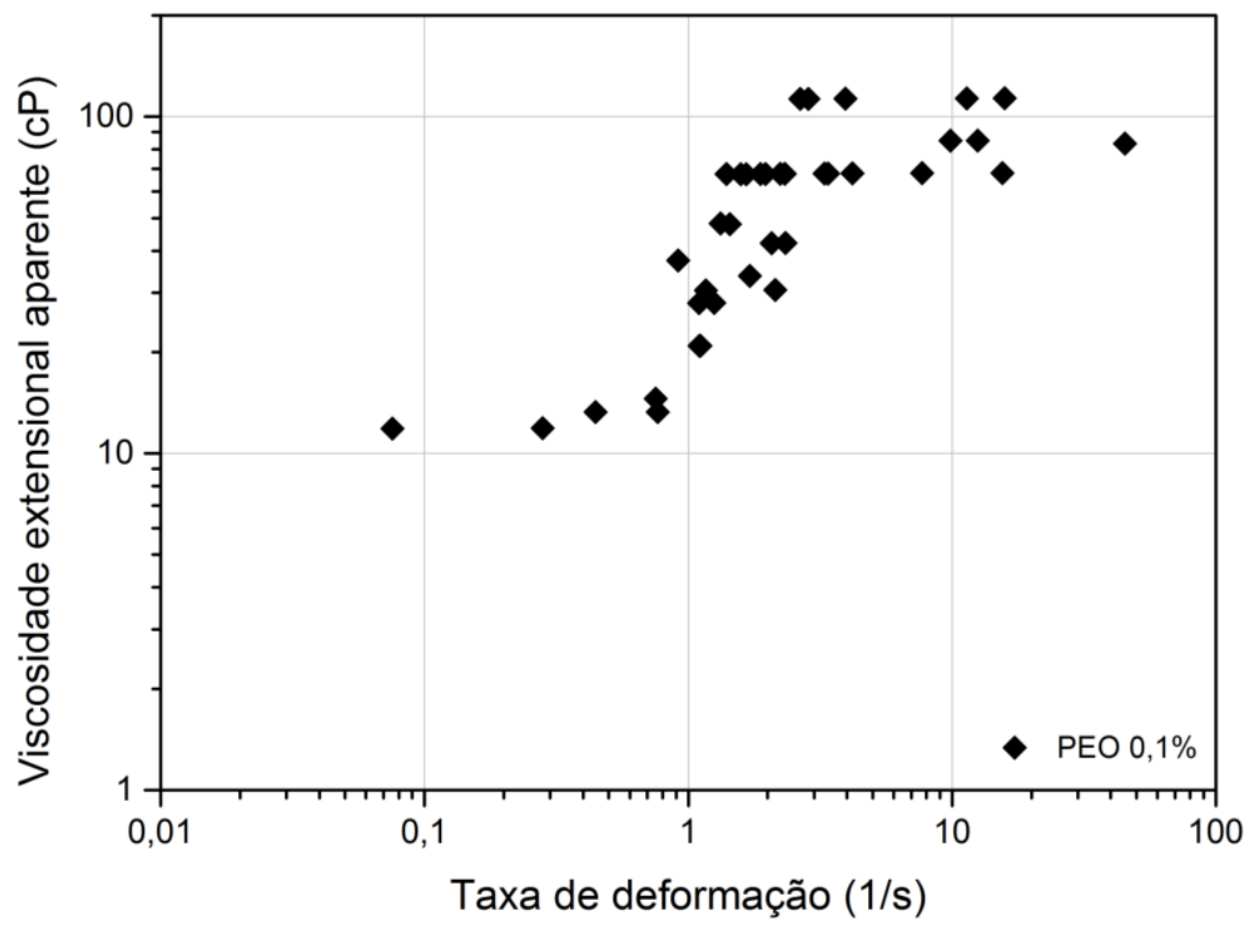

Figura 29 - Gráfico da viscosidade extensional aparente como uma função da taxa de deformação

Os dados obtidos podem ser analisados em função da razão de Trouton, que é a razão entre a viscosidade extensional no regime viscoelástico linear e a viscosidade de cisalhamento. Para fluidos newtonianos essa razão é constante e igual a 3. Para o poli(óxido de etileno), ela chega a valores maiores que 15 para a concentração de $0,1 \%$. Esse aumento da viscosidade extensional tem grande 
importância no escoamento de soluções de PEO em meios porosos, já que o escoamento através das gargantas de poros possui um forte componente extensional.

Para a solução de PEO de $0,1 \%$ a viscosidade de cisalhamento é quase constante, variando entre 5 e $8 \mathrm{cP}$ para uma ampla faixa de taxa de cisalhamento e a viscosidade extensional é aproximadamente $100 \mathrm{cP}$ a altas taxas de extensão.

\subsection{3.}

\section{Água destilada e solução de glicerina}

Para isolar o efeito elástico da solução de PEO no processo de deslocamento de óleo, foram realizados experimentos com uma solução aquosa de glicerina que apresenta uma viscosidade próxima da viscosidade de cisalhamento da solução polimérica.

Foram preparadas misturas de água com glicerina em diferentes proporções: $54 \%$, 53\% 52\% e 51\% de glicerina, para estimar qual delas deveria ser usada nos experimentos.

As amostras tiveram suas viscosidades medidas a $24^{\circ} \mathrm{C}$ no viscosímetro Ubbelohde utilizando o banho LAUDA Viscotemp 15 (Fig. 30). Os resultados são mostrados na tabela abaixo (Tab. 4).
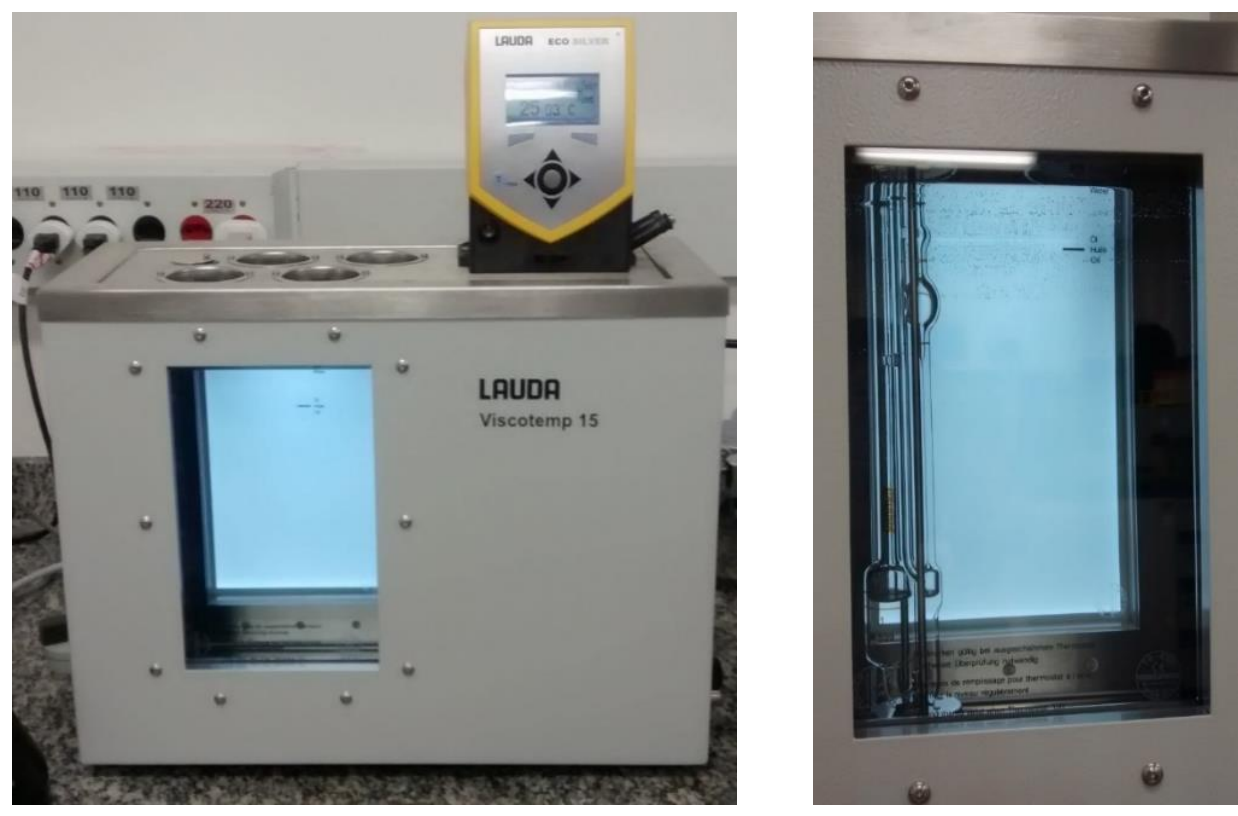

Figura 30 - Banho LAUDA Viscotemp 15 e viscosímetro Ubbelohde 
Tabela 4 - Viscosidade das misturas de água com glicerina

\begin{tabular}{cc|}
\hline Porcentagem de glicerina & Viscosidade dinâmica (cP) \\
\hline $54 \%$ & 9,4 \\
$53 \%$ & 8,8 \\
$52 \%$ & 8,2 \\
\hline $51 \%$ & 7,2 \\
\hline
\end{tabular}

Foi utilizado o fluido cuja viscosidade mais se aproximou do PEO 0,1\% a taxas de deformação entre 2 e 182 1/s, valor característico nos experimentos realizados, a solução com $51 \%$ de glicerina. Corante na cor azul foi adicionado ao fluido para facilitar a visualização do mesmo durante os experimentos de injeção.

Foram realizados também testes utilizando água destilada, filtrada e com corante na cor vermelha (Mix Coralim), para estudar o efeito da viscosidade do fluido injetado no processo de deslocamento de óleo na escala porosa.

\section{3. \\ Procedimento experimental}

Os experimentos consistiram na visualização do processo de deslocamento de óleo por injeção de diferentes líquidos: água, solução aquosa de glicerina e soluções poliméricas. Os processos são descritos a seguir:

1. Filtragem: Com o objetivo de evitar que impurezas prejudicassem o andamento dos experimentos, os fluidos a serem utilizados foram filtrados com uma bomba de vácuo Millipore, uma membrana de $5 \mu$ m Millipore e o sistema de filtração Nalgene. Foram filtrados o álcool etílico, o óleo mineral Drakeol® 7 e a água deionizada. O PEO não foi filtrado para não alterar suas propriedades, foi filtrada somente a água deionizada utilizada em seu preparo. Os diferentes equipamentos utilizados nesta etapa são apresentados na Figura 31. 

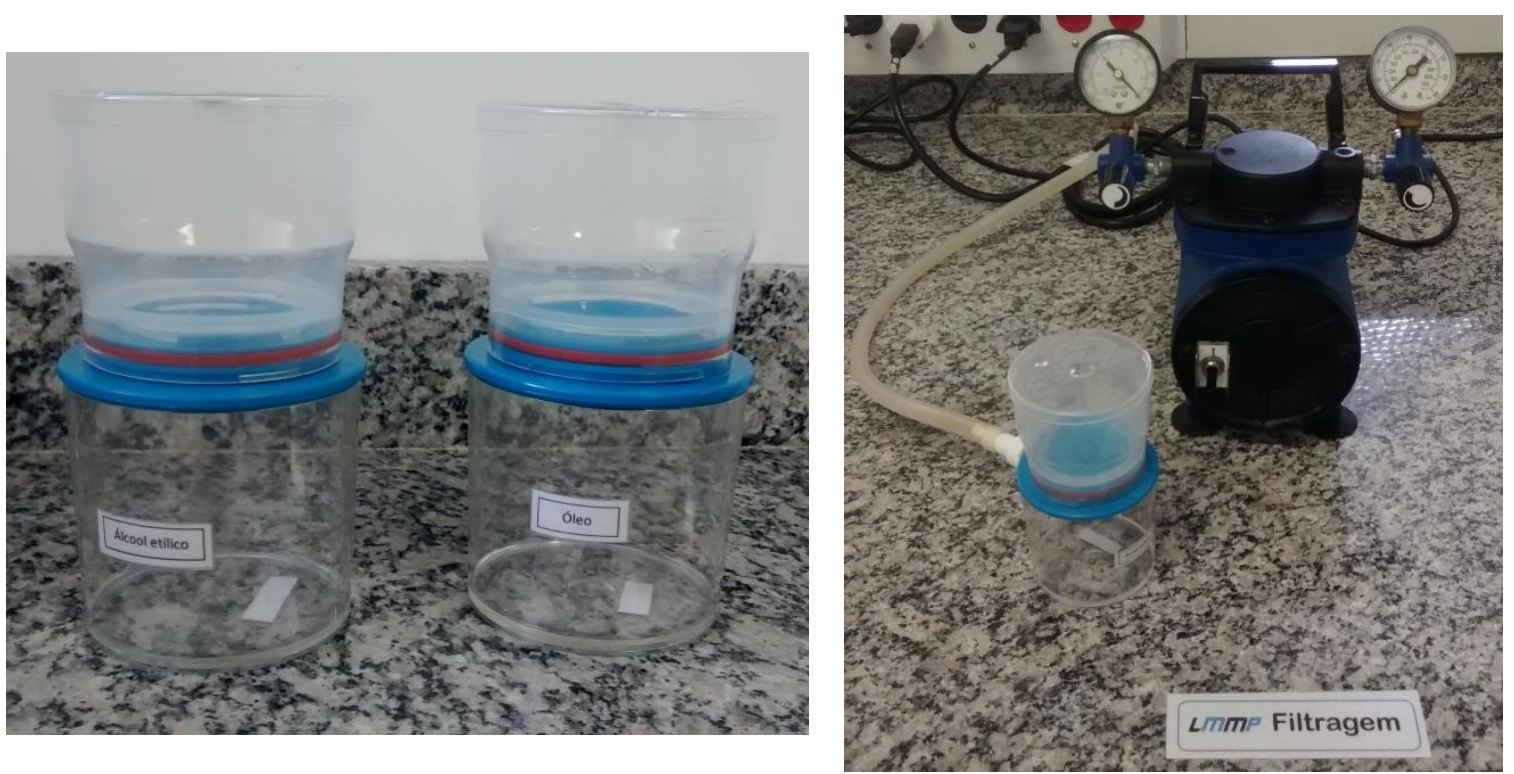

Figura 31 - Sistema de filtração e bomba de vácuo

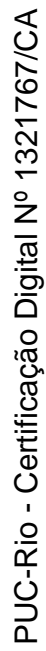

2. Limpeza do micromodelo (Fig. 32): Antes de iniciar cada experimento, foi realizada a limpeza do meio poroso com álcool etílico. Para isso, foi utilizada uma seringa de 25 mililitros Hamilton Gastigh $\AA$. Foram injetados $5 \mathrm{ml}$ a uma taxa de injeção de $6 \mathrm{ml} / \mathrm{h}, 5 \mathrm{ml}$ a $8 \mathrm{ml} / \mathrm{h}$ e $5 \mathrm{ml}$ a $10 \mathrm{ml} / \mathrm{h}$. Após a injeção, foi feita uma avaliação no microscópio para garantir que o dispositivo estava completamente preenchido por etanol.

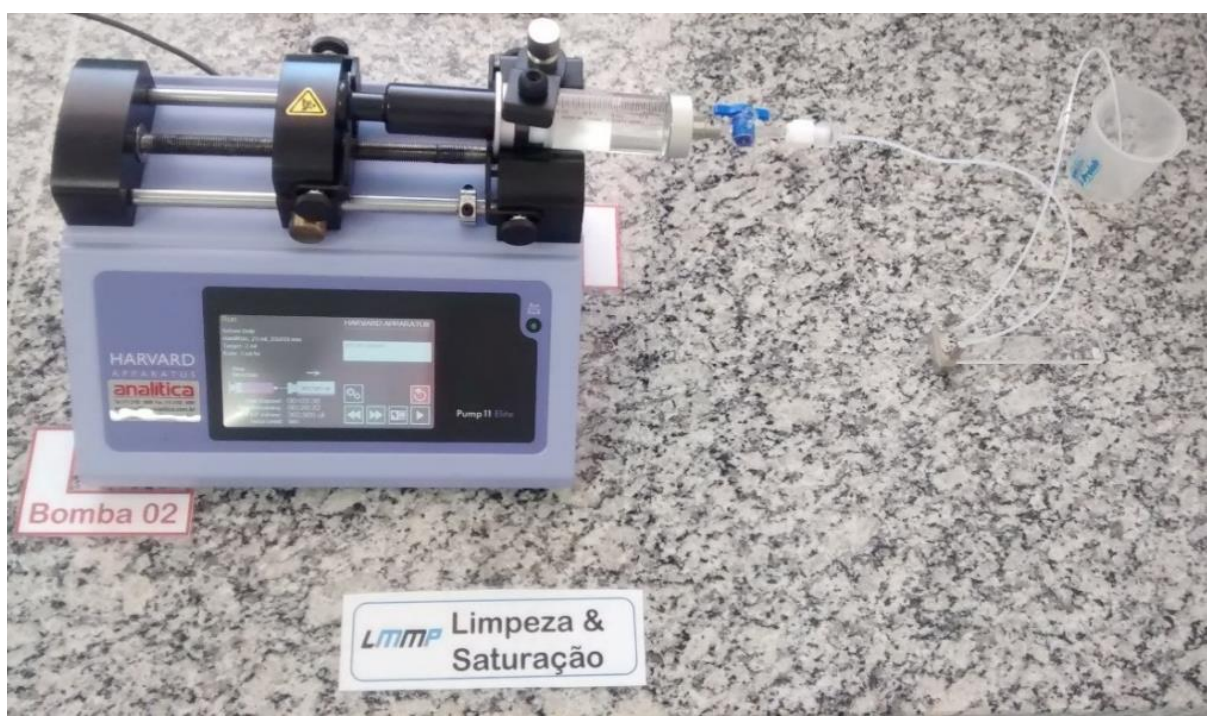

Figura 32 - Limpeza do dispositivo 
3. Secagem do micromodelo: secagem na estufa a $80^{\circ} \mathrm{C}$ por 30 minutos para assegurar que todo o etanol evaporou do dispositivo.

4. Saturação do meio poroso com óleo (Drenagem): Este processo consistiu em saturar o meio poroso com óleo mineral (Drakeol® 7) a uma taxa de injeção constante de $5 \mathrm{ml} / \mathrm{h}$, foram injetados $2 \mathrm{ml}$.

5. Deslocamento de óleo por injeção de fase aquosa (Embebição): Esta etapa consiste na injeção da fase aquosa (água destilada, PEO ou uma mistura de água com glicerina) com diferentes vazões. Para isso foi utilizada uma seringa de $2,5 \mathrm{ml}$ Hamilton Gastigh $\AA$. O procedimento foi feito fechando-se a válvula de três vias e trocando a seringa de óleo pela seringa contendo o fluido deslocante. Injeta-se um pequeno volume com o objetivo de retirar o óleo no interior da válvula antes de começar a injeção. É importante também verificar as conexões com o objetivo de impedir possíveis vazamentos. São injetados então dois volumes porosos (60 microlitros) da fase aquosa.

6. Determinação da saturação de óleo residual: Um dos problemas nos estudos com dispositivos de microfluídica, são os pequenos volumes envolvidos nos experimentos, nesse caso apenas 30 microlitros de volume poroso. Assim, para a determinação da saturação de óleo residual em diferentes regiões do dispositivo, optou-se por utilizar um código em MATLAB para processamento das imagens.

O código funciona com duas entradas, a primeira delas é uma foto de uma região do microchip totalmente saturada com óleo, o programa cria uma máscara que separa a região útil do volume sólido. A segunda entrada é uma foto tirada ao final da injeção da fase aquosa. O programa compara as duas fotos e como resultado ele mostra a porcentagem de saturação do fluido deslocante, o restante é, portanto, a porcentagem de óleo residual presente naquela região. 


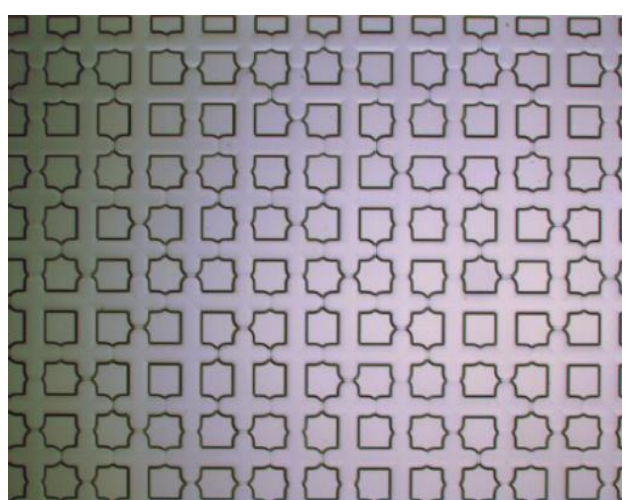

Micromodelo saturado de óleo

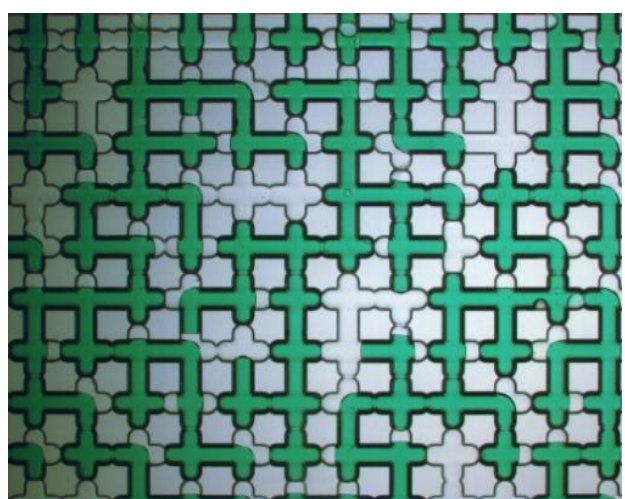

Perfil de saturação após a injeção da fase aquosa

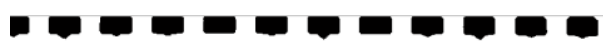

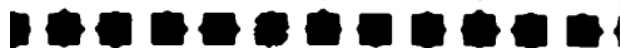

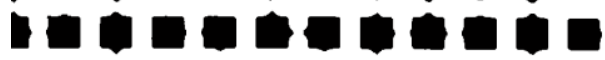

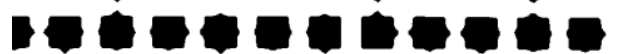

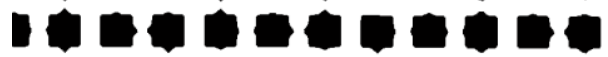

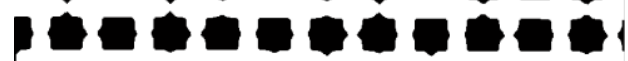

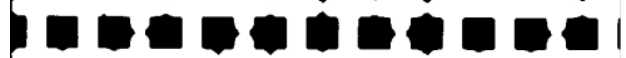

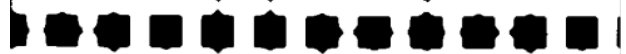

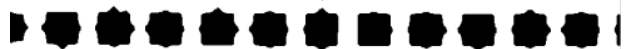

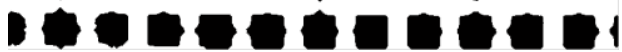

Máscara criada pelo programa

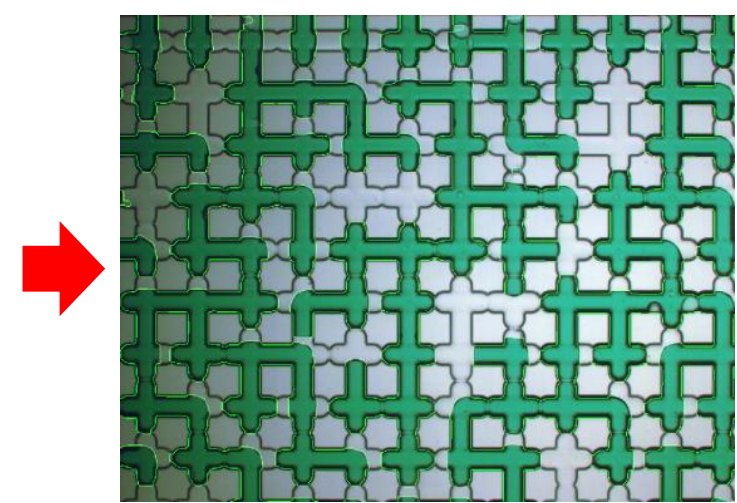

Resultado (Sor $=23 \%$ )

Figura 33 - Etapas do código em MATLAB

A Figura 33 apresenta as etapas do código de processamento das imagens até o cálculo da saturação residual de óleo na imagem. 


\section{3 \\ Resultados}

Nesse capítulo serão apresentados e discutidos os resultados dos experimentos de deslocamento de óleo por soluções poliméricas através de um meio poroso.

Para estimar os valores de viscosidade das soluções poliméricas é importante estimar a taxa de cisalhamento do fluxo. A taxa de cisalhamento foi calculada usando a seguinte expressão, utilizada para escoamento em um tubo:

$$
\dot{\gamma}=\frac{8 \bar{u}}{D}\left(\frac{3 n+1}{4 n}\right)
$$

onde:

$\dot{\gamma}$ é a taxa de cisalhamento

$\bar{u}$ é a velocidade média

$D$ é o diâmetro do tubo

$n$ é o expoente do modelo Power Law

A velocidade média foi calculada com a vazão total dividida pelo número de canais na entrada (40 canais) e o diâmetro de cada tubo $(105 \mu \mathrm{m})$.

A viscosidade característica foi estimada utilizando a equação de PowerLaw:

$$
\eta(\dot{\gamma})=k \dot{\gamma}^{n-1}
$$

onde:

k é o índice de consistência

$n$ é o expoente do modelo Power Law

O expoente $n$ mede o grau de desvio do comportamento newtoniano. Quando o expoente é menor que 1, o fluido assume comportamento pseudoplástico, maior que 1 , o fluido é do tipo dilatante, e se for igual a 1 , o fluido é newtoniano. 
Os valores de $n$ e $k$ (Tabela 5 ) foram obtidos através da curva da viscosidade em função da taxa de cisalhamento, como mostrado na Figura 34.

Tabela 5 - Valores dos coeficientes $n$ e $k$

\begin{tabular}{ccc}
\hline Intervalo (1/s) & $\boldsymbol{n}$ & $\boldsymbol{k}$ \\
\hline 1 a 10 & 0,965 & 8,001 \\
10 a 1000 & 0,825 & 11,256 \\
\hline
\end{tabular}

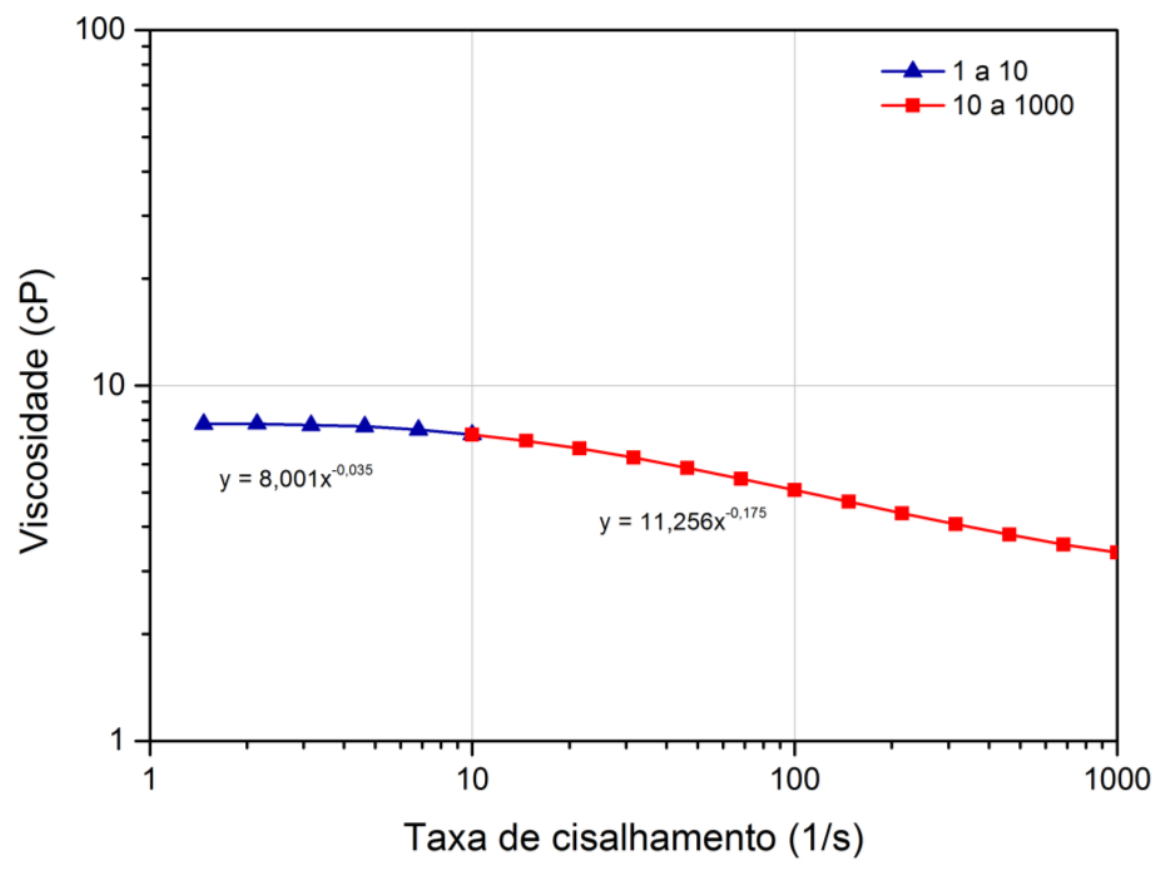

Figura 34 - Curva da viscosidade em função da taxa de cisalhamento no intervalo entre 1 e 1000 1/s

Nos experimentos realizados para as taxas de injeção de $0,039 \mathrm{ml} / \mathrm{h}$ a 4,16 $\mathrm{ml} / \mathrm{h}$ as taxas de deformação $(\dot{\gamma})$ variaram entre 2 e 182 1/s.

A análise dos resultados foi feita em relação ao número de capilaridade, uma relação adimensional de forças viscosas e forças capilares.

$$
C a=\frac{\mu v}{\sigma}
$$

onde:

Ca é o número de capilaridade $\mu$ é a viscosidade do fluido deslocante 
$v$ é a velocidade de Darcy

$\sigma$ é a tensão interfacial entre as fases deslocante e deslocada

A velocidade de Darcy é definida como a vazão volumétrica de fluido dividida pela área da seção transversal do meio poroso.

Foram analisadas seis áreas no micromodelo, a entrada, a saída e quatro regiões no meio do dispositivo, como mostrado na Figura 35. As áreas serão identificadas nas imagens como A1, A2, A3, A4, A5 e A6.

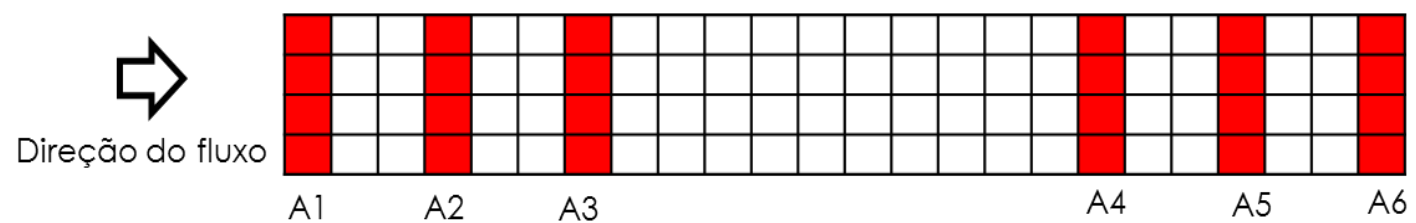

Figura 35 - Áreas analisadas no micromodelo

Foram conduzidos dois procedimentos diferentes para a realização dos testes experimentais. O primeiro deles (Procedimento 1) consistiu em saturar o micromodelo com óleo e injetar a fase aquosa (água, solução de glicerina ou solução de PEO) aumentando a taxa de injeção. Desta forma, a condição inicial de saturação das fases no microdispositivo em cada experimento era o resultado do experimento realizado a uma vazão mais baixa. No segundo (Procedimento 2), foram injetadas as fases aquosas a quatro taxas de injeção fixas $(0,065 \mathrm{ml} / \mathrm{h}, 0,52$ $\mathrm{ml} / \mathrm{h}, 2,08 \mathrm{ml} / \mathrm{h}$ e $4,16 \mathrm{ml} / \mathrm{h}$ ) com o micromodelo saturado de óleo. Desta forma, a condição inicial de saturação das fases foi a mesma para cada experimento.

\section{1.}

\section{Procedimento 1}

Consistiu na saturação do micromodelo com óleo e injeção das fases aquosas: água, solução de glicerina e solução de PEO, iniciando com taxa de injeção de $0,039 \mathrm{ml} / \mathrm{h}$ e aumentando para 0,065 ml/h, 0,13 ml/h, 0,26 ml/h, 0,52 $\mathrm{ml} / \mathrm{h}, 1,04 \mathrm{ml} / \mathrm{h}, 1,56 \mathrm{ml} / \mathrm{h}$ e 2,08 ml/h. Ao final da injeção de dois volumes porosos com cada taxa de injeção, quando a saturação já estava constante, foram tiradas fotos das seis regiões do micromodelo.

A Figura 36 apresenta a imagem da região $A 3$ para a menor vazão $(Q=$ $0,039 \mathrm{ml} / \mathrm{h}$ ) para as três fases aquosas utilizadas. Pode-se observar claramente o 
efeito da viscosidade da fase injetada. A água se desloca formando um caminho preferencial ("viscous finger"), deixando grande parte do espaço poroso saturado com óleo.

As imagens com solução de glicerina e PEO, que possuem viscosidade aproximadamente sete vezes maior do que a viscosidade da água apresentam um deslocamento mais uniforme. Apesar desta maior uniformidade da frente de avanço, pode-se observar claramente gânglios de óleo imóveis, cercados pela fase aquosa.

As Figuras 37 a 43 apresentam as imagens da região A3 para as diferentes vazões testadas. Para vazões até $Q=0,26 \mathrm{ml} / \mathrm{h}$ (Fig. 39), não houve alteração da saturação das fases na região A3. Até este valor, o processo é dominado por capilaridade e o aumento de pressão no escoamento da fase aquosa, causado pelo aumento de vazão, não foi suficiente para mobilizar óleo.

Para $Q=0,52 \mathrm{ml} / \mathrm{h}$ (Fig. 41), pode-se observar a invasão da fase aquosa, principalmente no caso de injeção de água. O aumento sequencial da vazão levou a gânglios de óleo cada vez menores (Fig. 43).
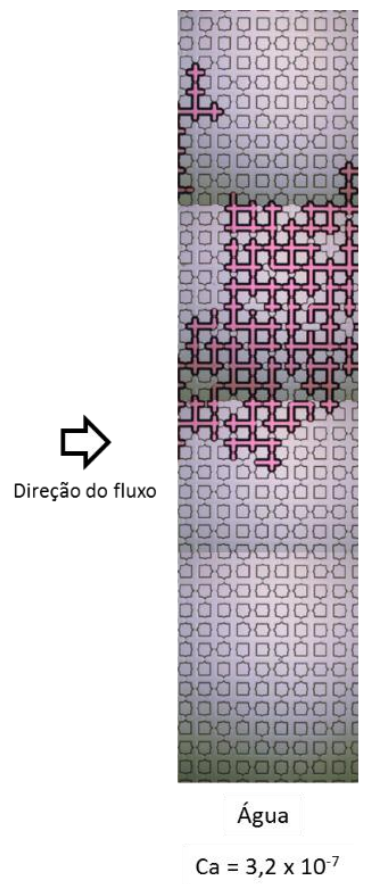

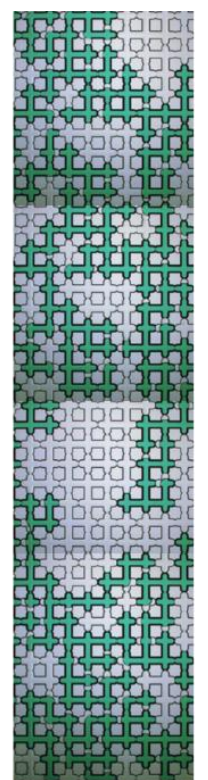

Glicerina $\mathrm{Ca}=2,4 \times 10^{-6}$

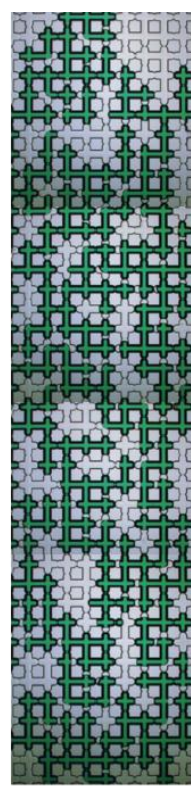

PEO

$\mathrm{Ca}=2,3 \times 10^{-6}$
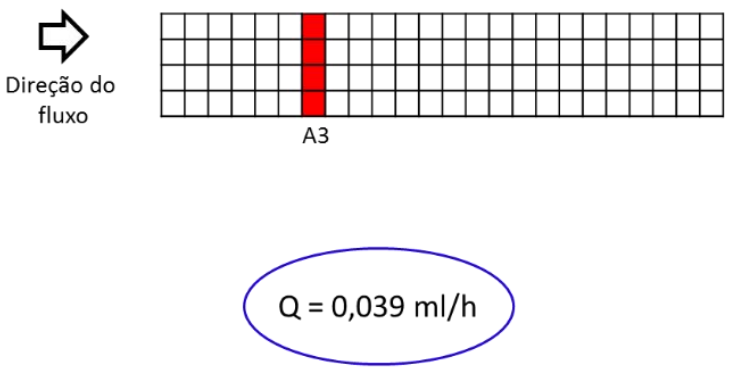

Sor Água $=73,6 \%$ Sor Glicerina $=40,3 \%$ Sor $\mathrm{PEO}=30,7 \%$

Figura 36 - Perfis de saturação ao final da injeção a $0,039 \mathrm{ml} / \mathrm{h}$ na região $A 3$ e as saturações de óleo residual 


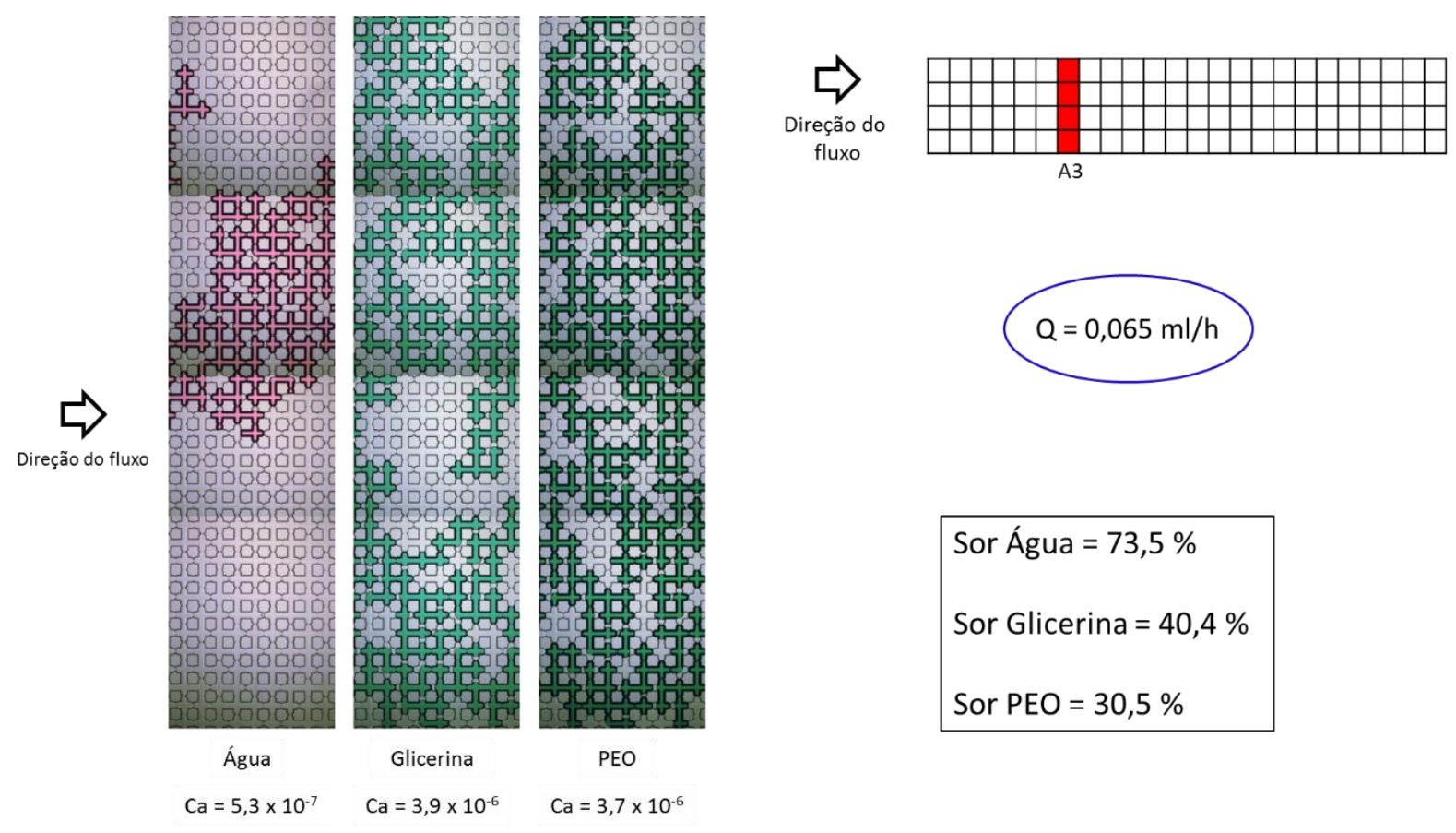

Figura 37 - Perfis de saturação ao final da injeção a $0,065 \mathrm{ml} / \mathrm{h}$ na região $A 3$ e as saturações de óleo residual
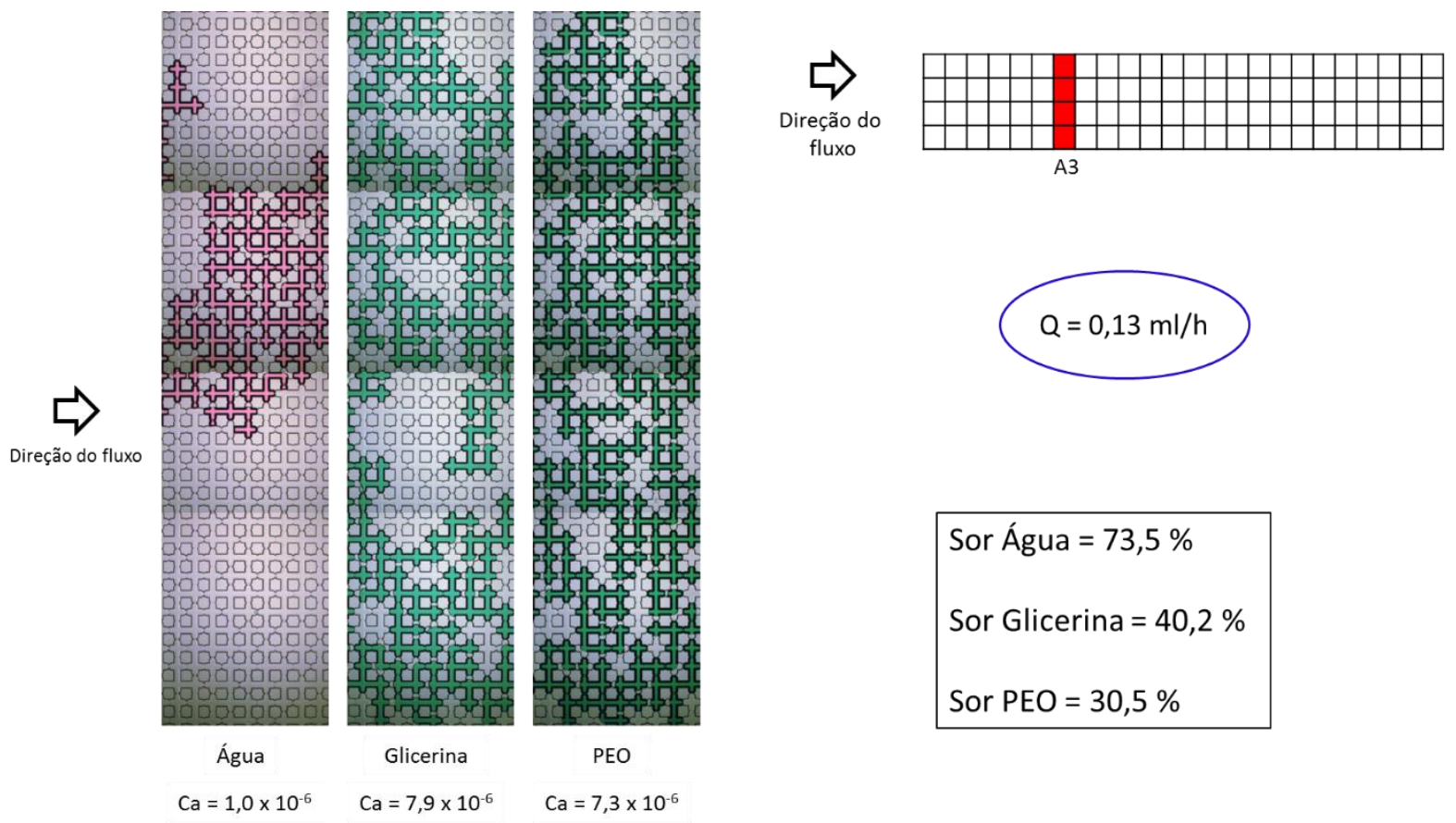

\begin{tabular}{|l} 
Sor Água $=73,5 \%$ \\
Sor Glicerina $=40,2 \%$ \\
Sor PEO $=30,5 \%$
\end{tabular}

Figura 38 - Perfis de saturação ao final da injeção a $0,13 \mathrm{ml} / \mathrm{h}$ na região $\mathrm{A} 3$ e as saturações de óleo residual 


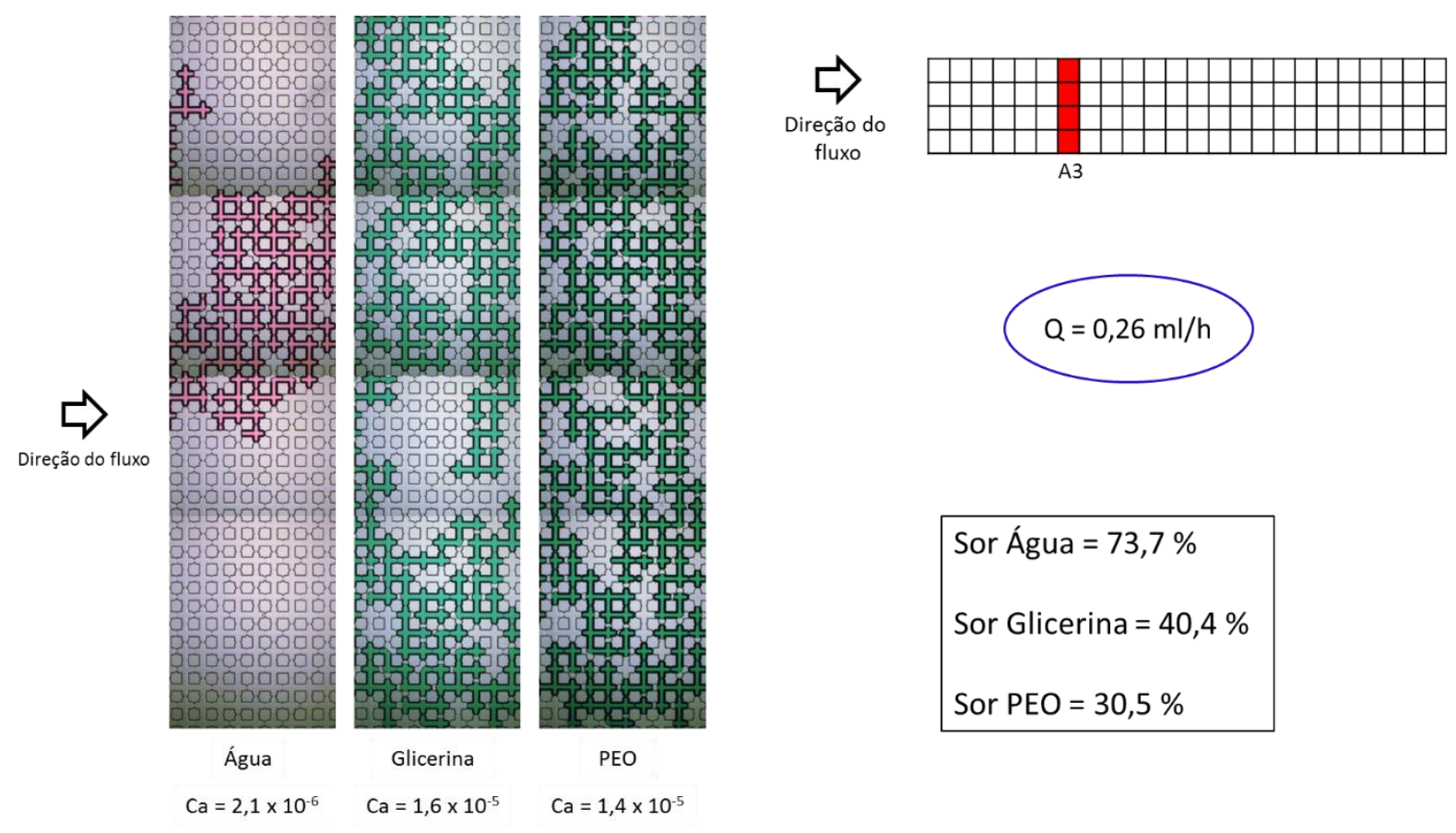

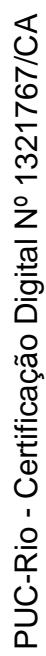

Figura 39 - Perfis de saturação ao final da injeção a $0,26 \mathrm{ml} / \mathrm{h}$ na região $A 3$ e as saturações de óleo residual
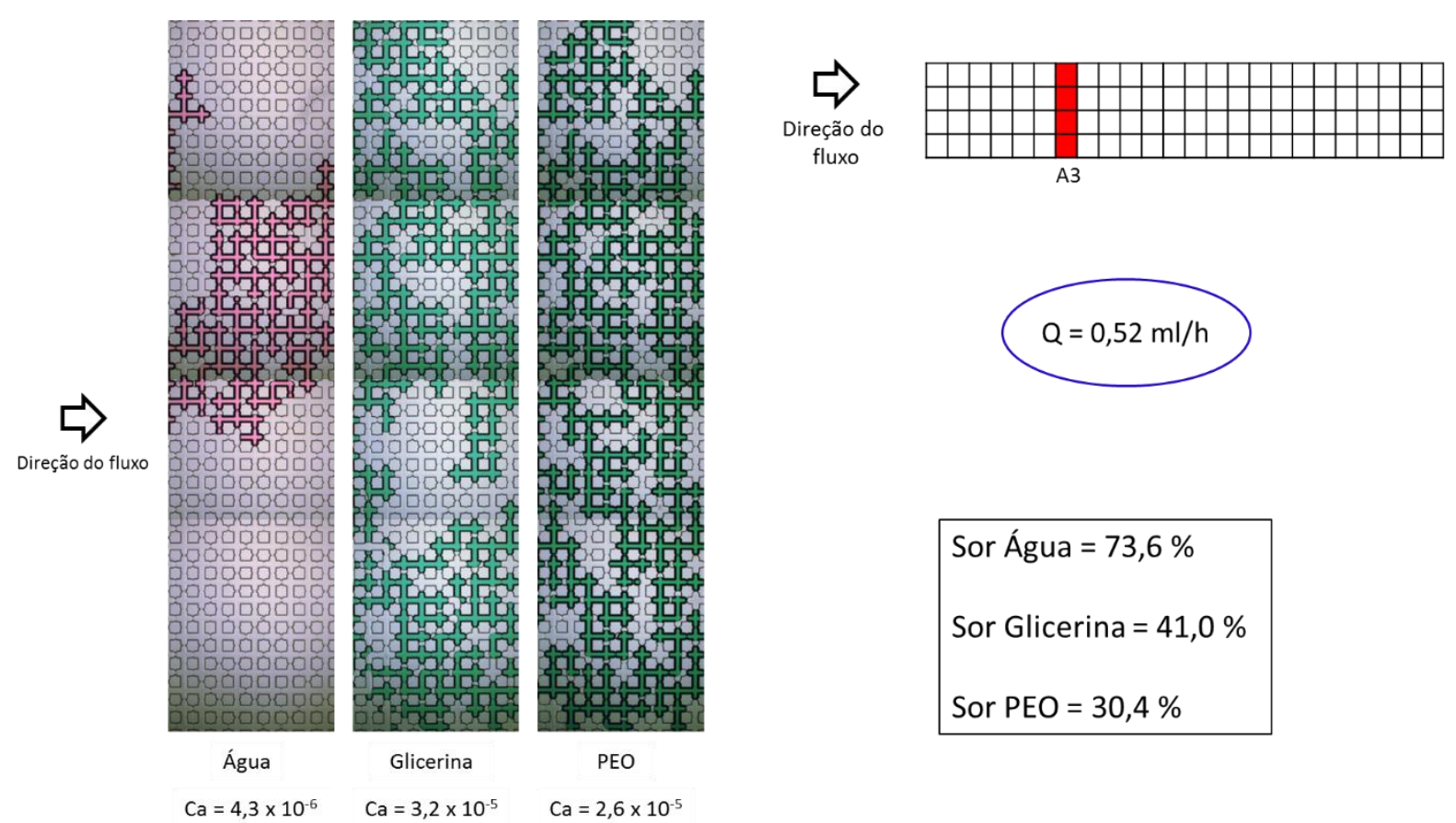

Sor Água $=73,6 \%$

Sor Glicerina $=41,0 \%$

Sor PEO $=30,4 \%$

Figura 40 - Perfis de saturação ao final da injeção a $0,52 \mathrm{ml} / \mathrm{h}$ na região $\mathrm{A3}$ e as saturações de óleo residual 


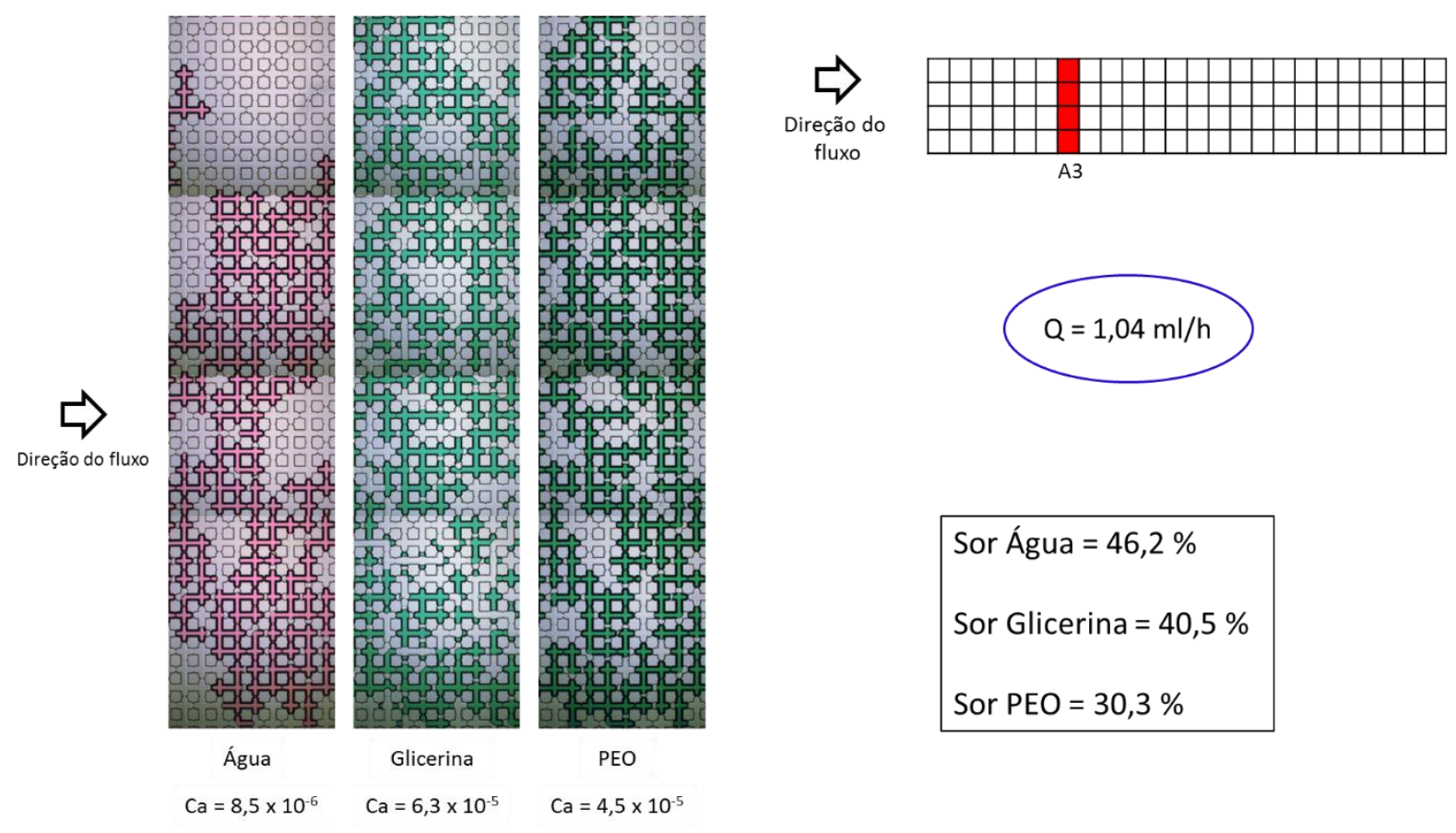

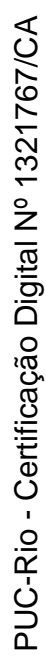

Figura 41 - Perfis de saturação ao final da injeção a 1,04 ml/h na região $A 3$ e as saturações de óleo residual

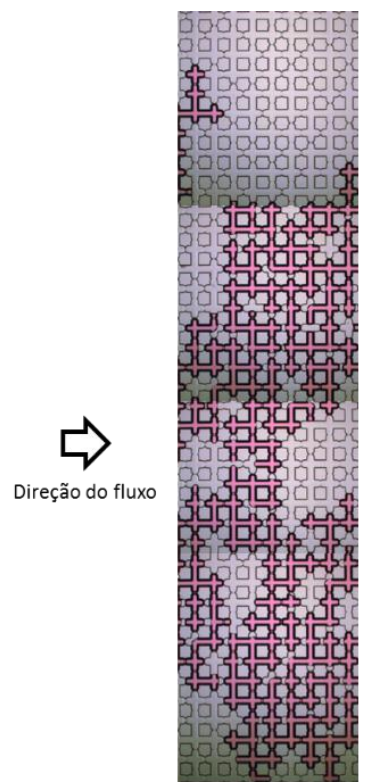

Água $\mathrm{Ca}=1,3 \times 10^{-5}$

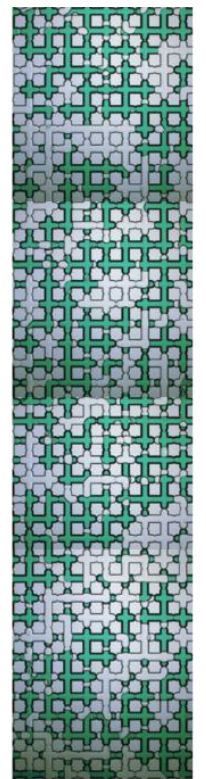

Glicerina $\mathrm{Ca}=9,5 \times 10^{-5}$

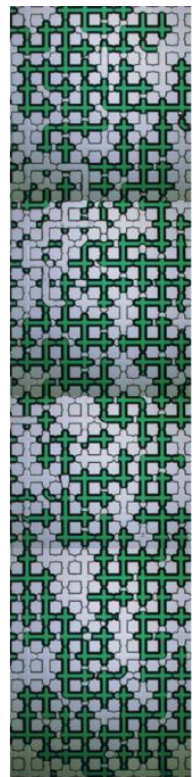

PEO
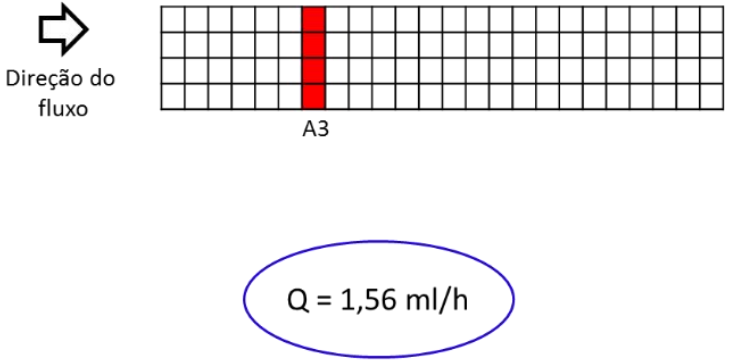

Sor Água $=46,5 \%$ Sor Glicerina = 39,1 \% Sor PEO $=32,5 \%$

Figura 42 - Perfis de saturação ao final da injeção a 1,56 ml/h na região A3 e as saturações de óleo residual 


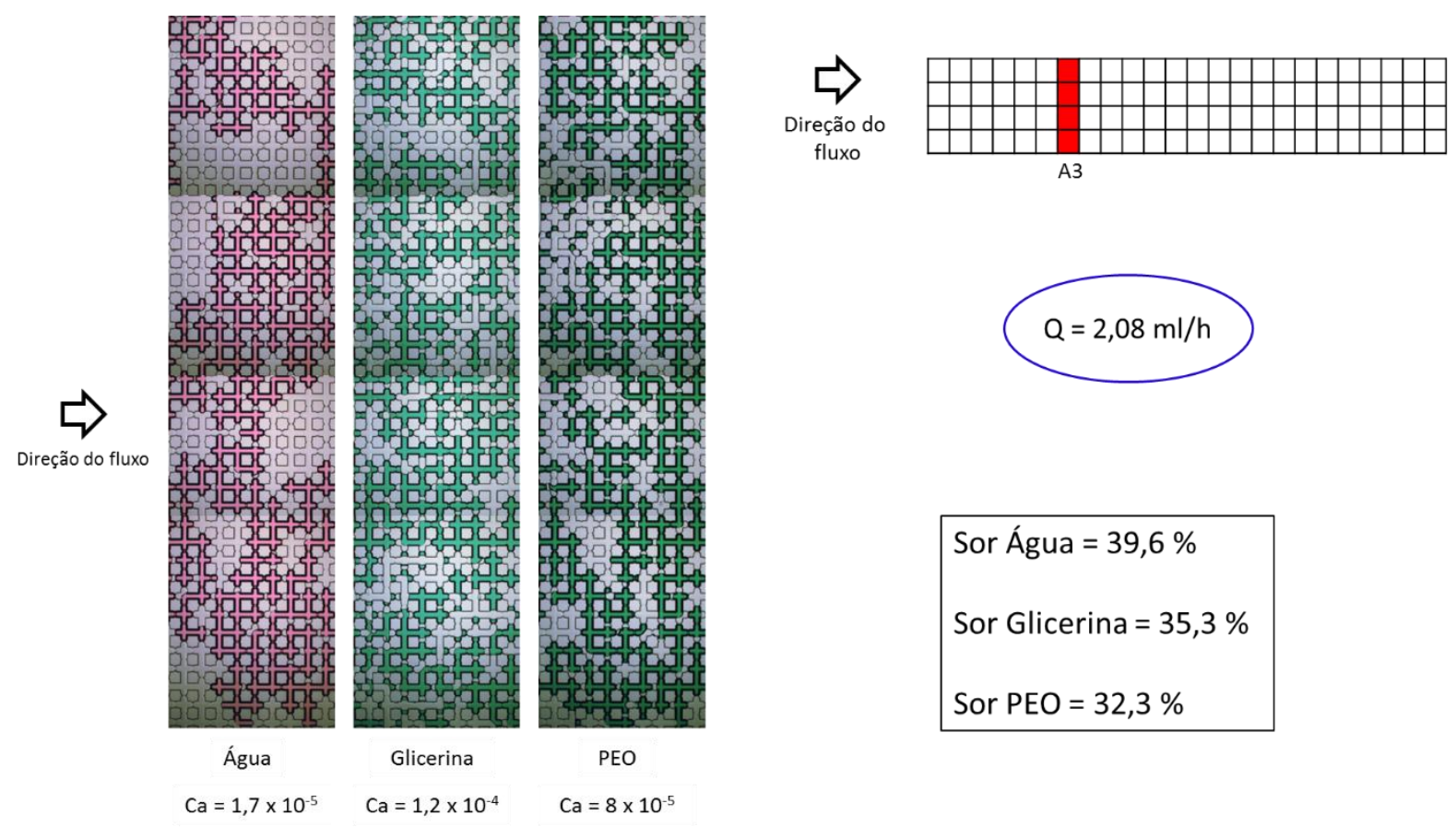

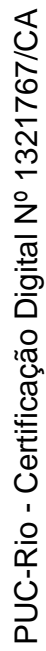

Figura 43 - Perfis de saturação ao final da injeção a $2,08 \mathrm{ml} / \mathrm{h}$ na região $\mathrm{A3}$ e as saturações de óleo residual

As imagens da região A4 para as diferentes vazões são apresentadas nas Figuras 44 a 51 . O comportamento foi semelhante à região $A 3$. A saturação das fases só muda para $Q \geq 0,52 \mathrm{ml} / \mathrm{h}$. Para vazões menores do que este valor, a diferença de pressão da fase aquosa não é suficiente para mobilizar gânglios de óleo. 


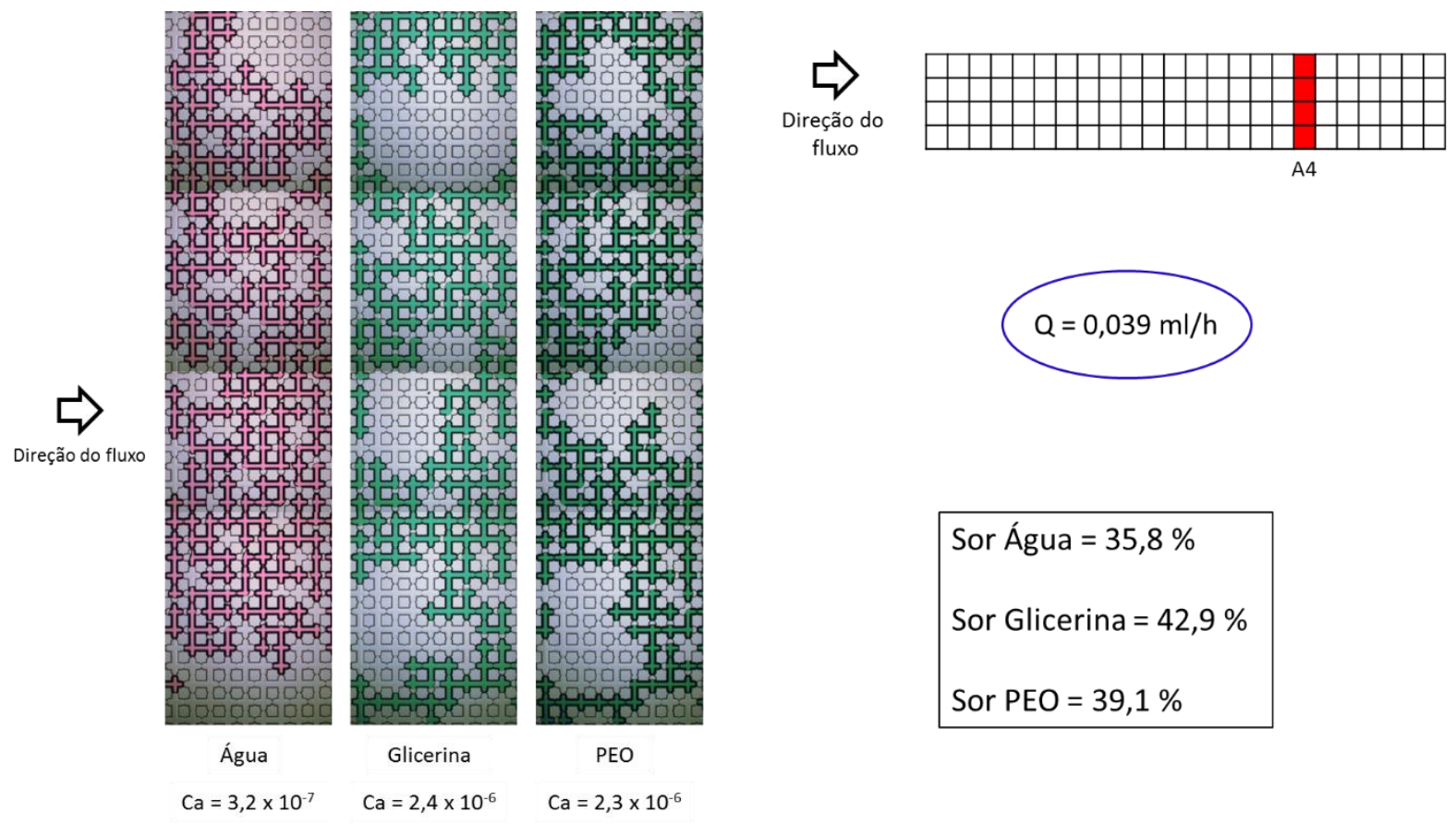

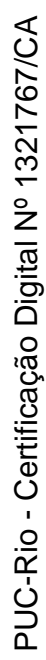

Figura 44 - Perfis de saturação ao final da injeção a $0,039 \mathrm{ml} / \mathrm{h}$ na região $A 4$ e as saturações de óleo residual

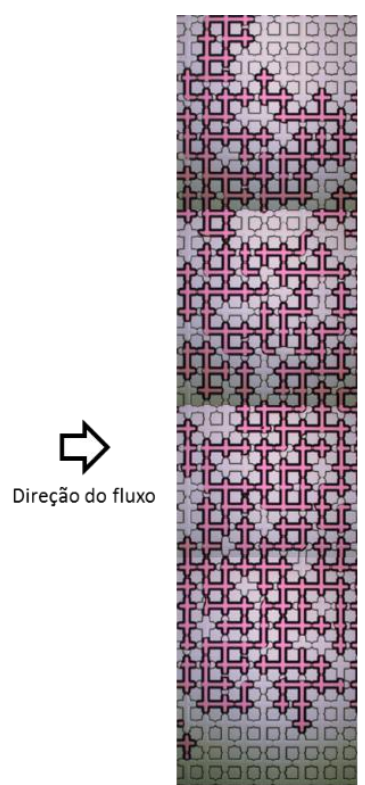

$\frac{\text { Água }}{C a=5,3 \times 10^{-7}}$

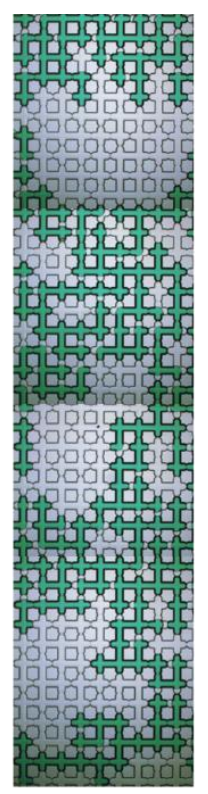

Glicerina

$\mathrm{Ca}=3,9 \times 10^{-6}$

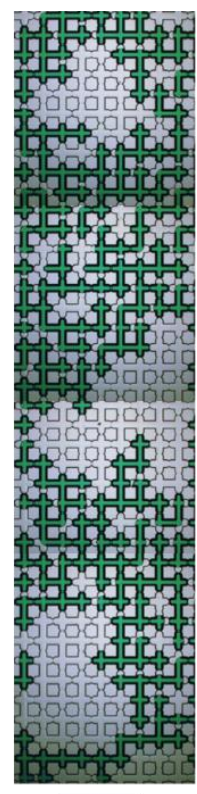

PEO
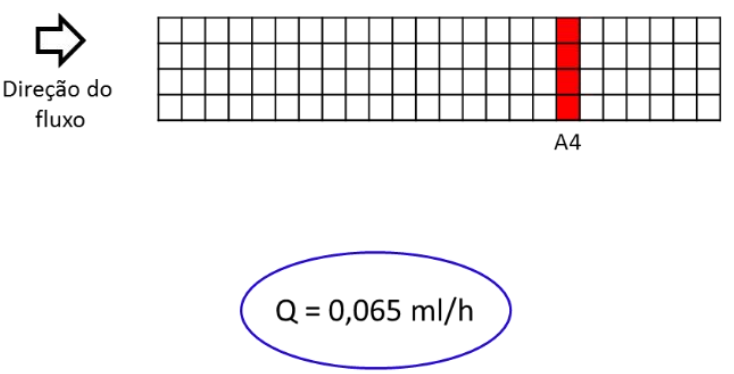

Sor Água $=35,7 \%$

Sor Glicerina $=43,1 \%$

Sor PEO = 39,1 \%

Figura 45 - Perfis de saturação ao final da injeção a $0,065 \mathrm{ml} / \mathrm{h}$ na região $\mathrm{A4}$ e as saturações de óleo residual 


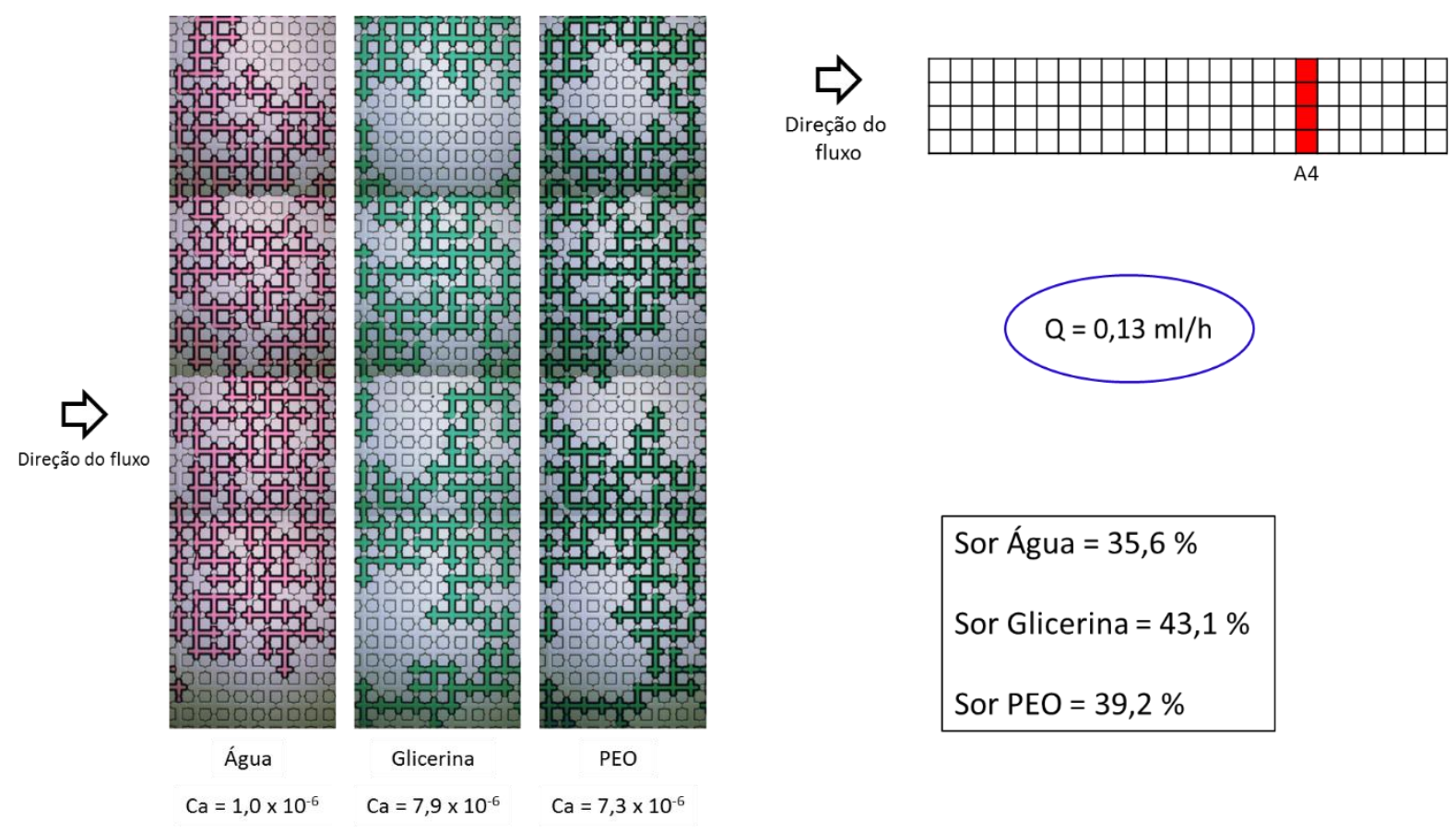

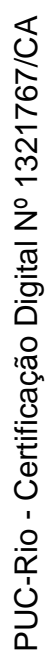

Figura 46 - Perfis de saturação ao final da injeção a $0,13 \mathrm{ml} / \mathrm{h}$ na região $\mathrm{A4}$ e as saturações de óleo residual

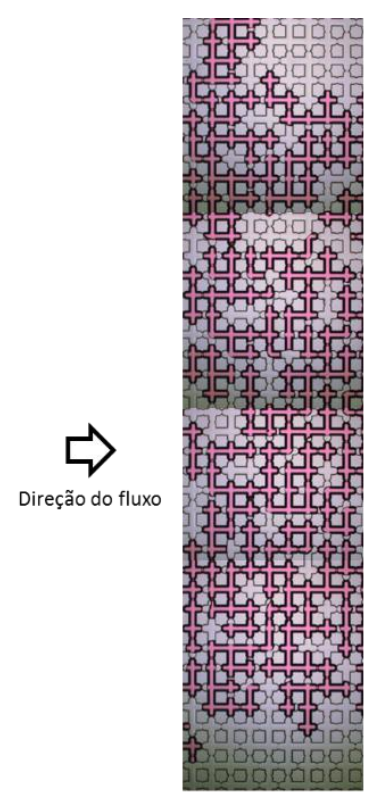

Água $\mathrm{Ca}=2,1 \times 10^{-6}$

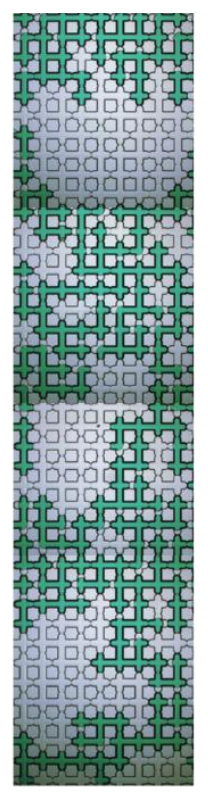

Glicerina $\mathrm{Ca}=1,6 \times 10^{-5}$

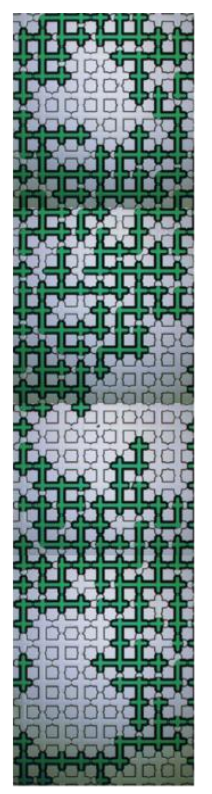

PEO

$\mathrm{Ca}=1,4 \times 10^{-5}$
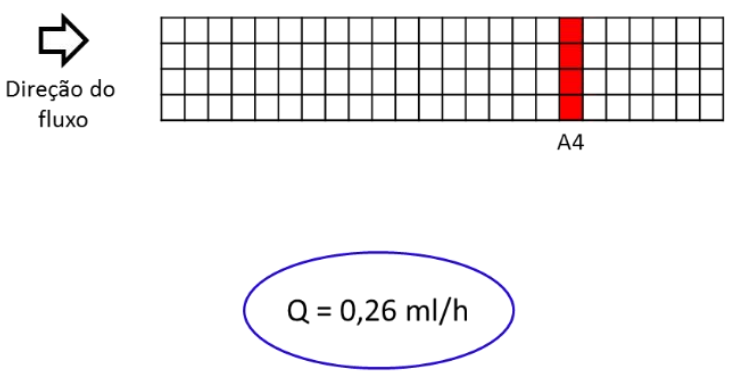

Sor Água = 35,6 \%

Sor Glicerina $=43 \%$

Sor PEO = 39,1 \%

Figura 47 - Perfis de saturação ao final da injeção a 0,26 ml/h na região A4 e as saturações de óleo residual 


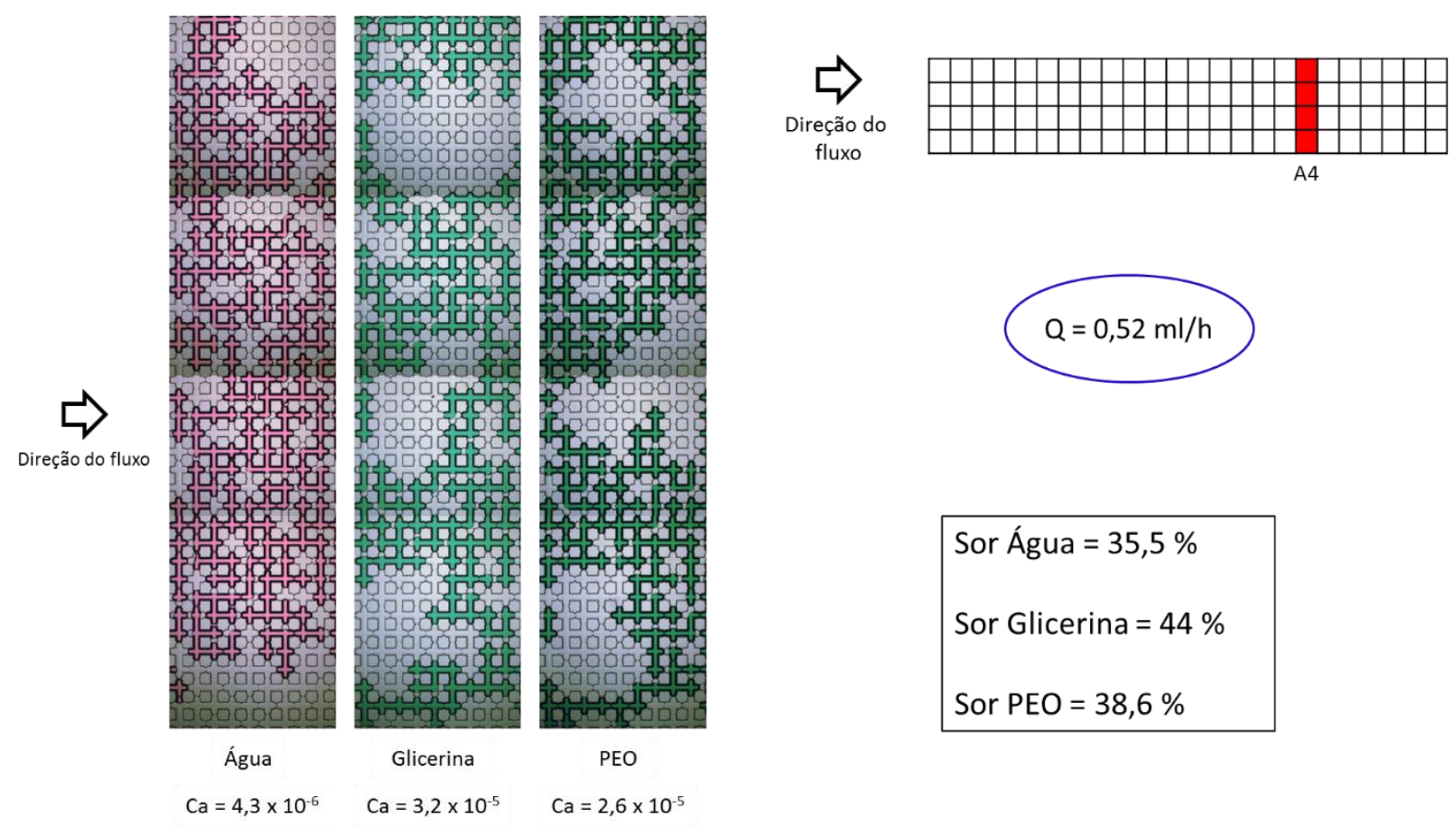

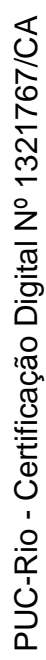

Figura 48 - Perfis de saturação ao final da injeção a $0,52 \mathrm{ml} / \mathrm{h}$ na região $\mathrm{A4}$ e as saturações de óleo residual
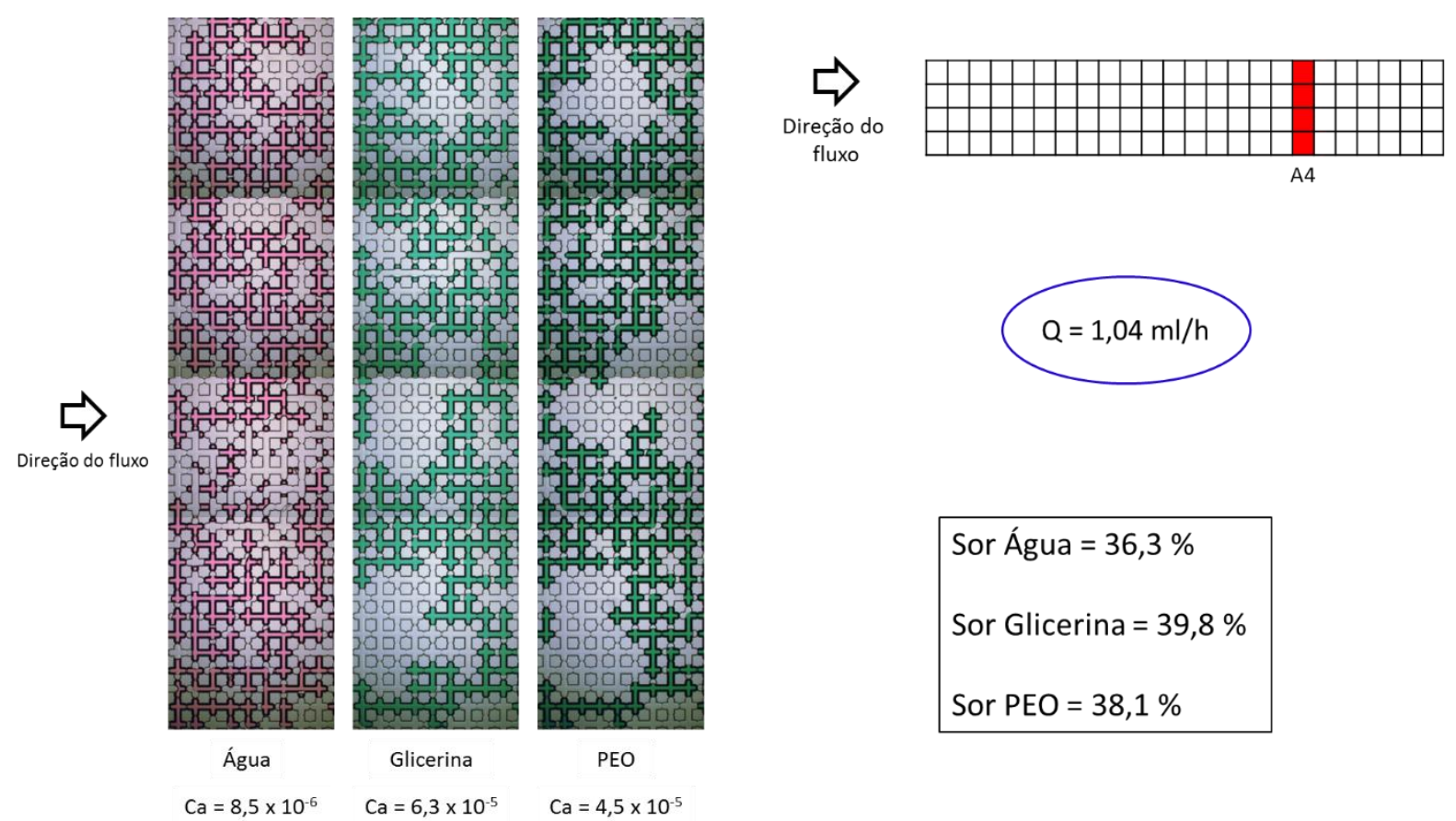

Sor Água $=36,3 \%$

Sor Glicerina $=39,8 \%$

Sor $\mathrm{PEO}=38,1 \%$

Figura 49 - Perfis de saturação ao final da injeção a 1,04 ml/h na região $\mathrm{A4}$ e as saturações de óleo residual 


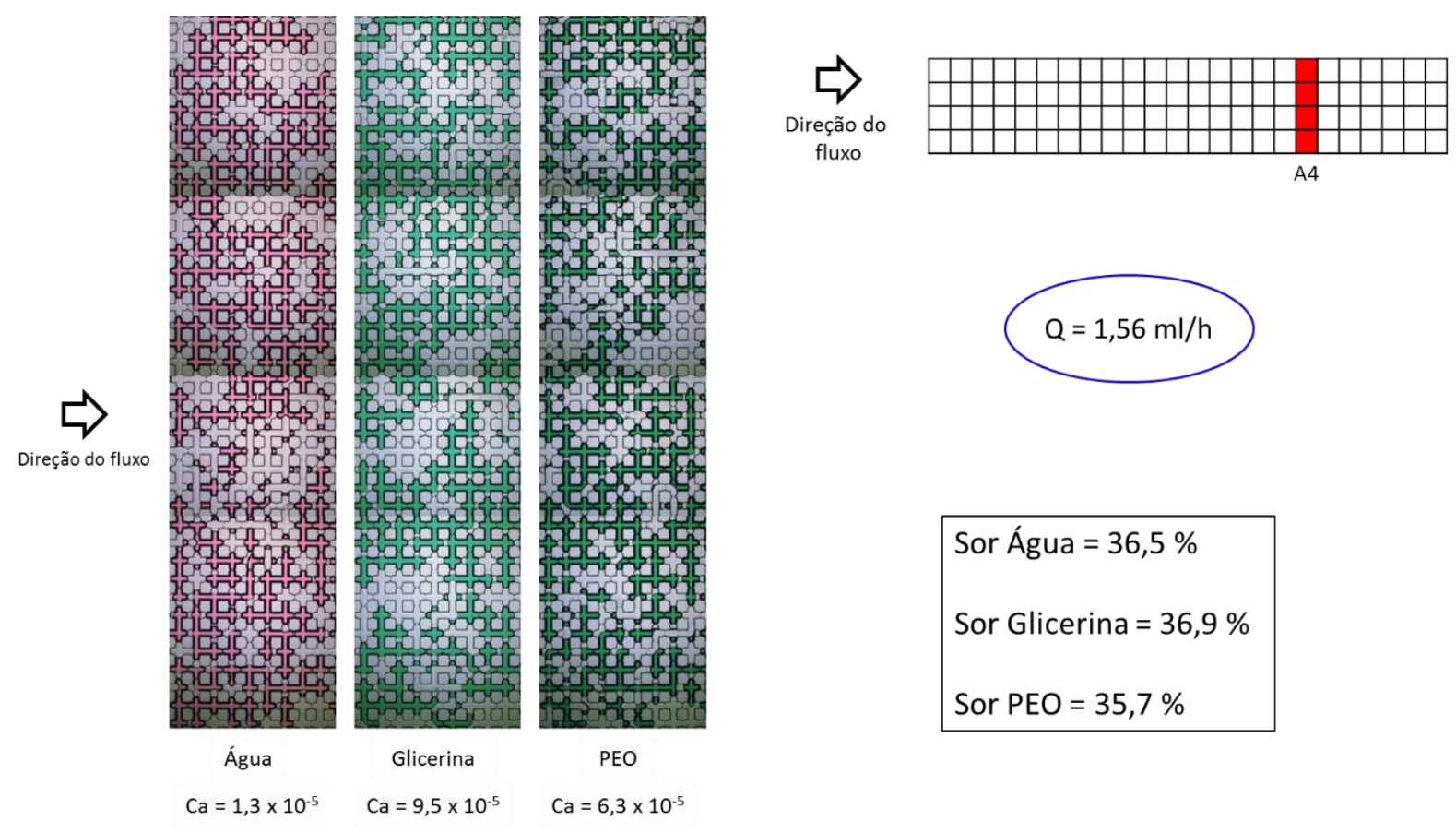

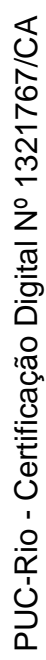

Figura 50 - Perfis de saturação ao final da injeção a 1,56 ml/h na região $A 4$ e as saturações de óleo residual

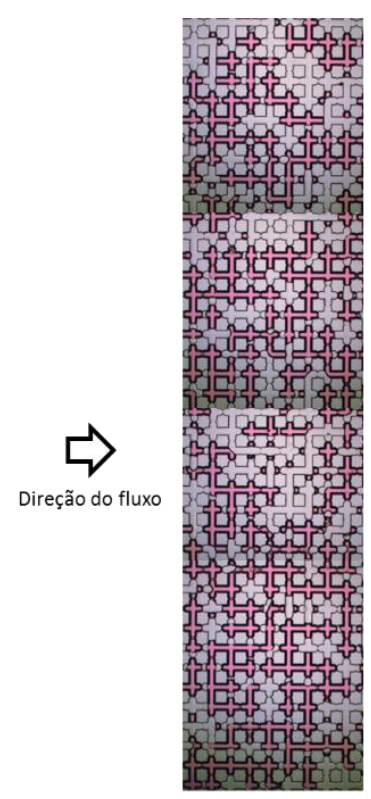

$\frac{\text { Água }}{\mathrm{Ca}=1,7 \times 10^{-5}}$

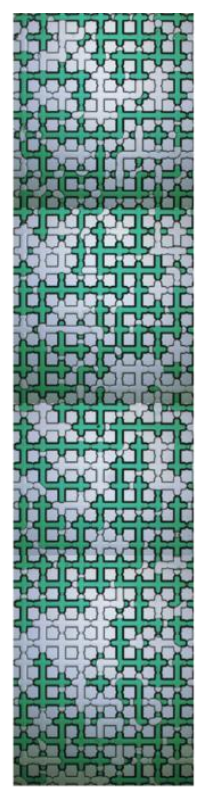

Glicerina $\mathrm{Ca}=1,2 \times 10^{-4}$

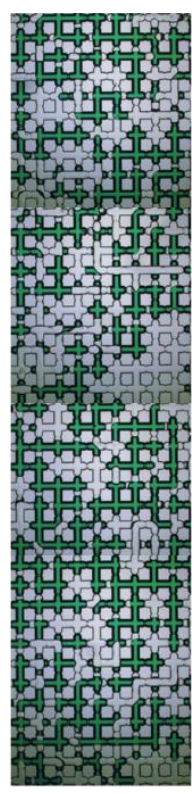

PEO

$\mathrm{Ca}=8 \times 10^{-5}$
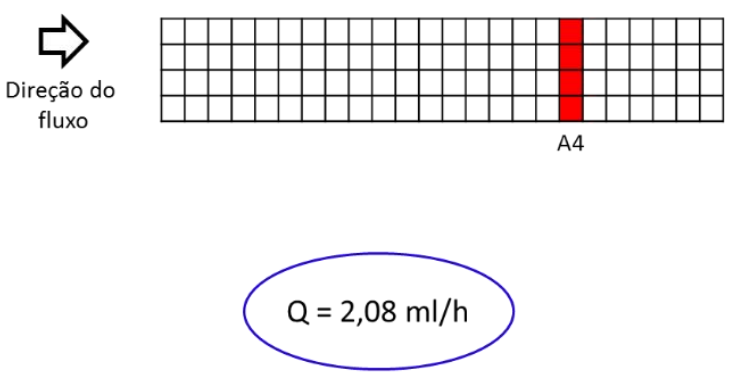

Sor Água = 37,1 \%

Sor Glicerina = $34 \%$

Sor PEO $=35,4 \%$

Figura 51 - Perfis de saturação ao final da injeção a 2,08 $\mathrm{ml} / \mathrm{h}$ na região A4 e as saturações de óleo residual 


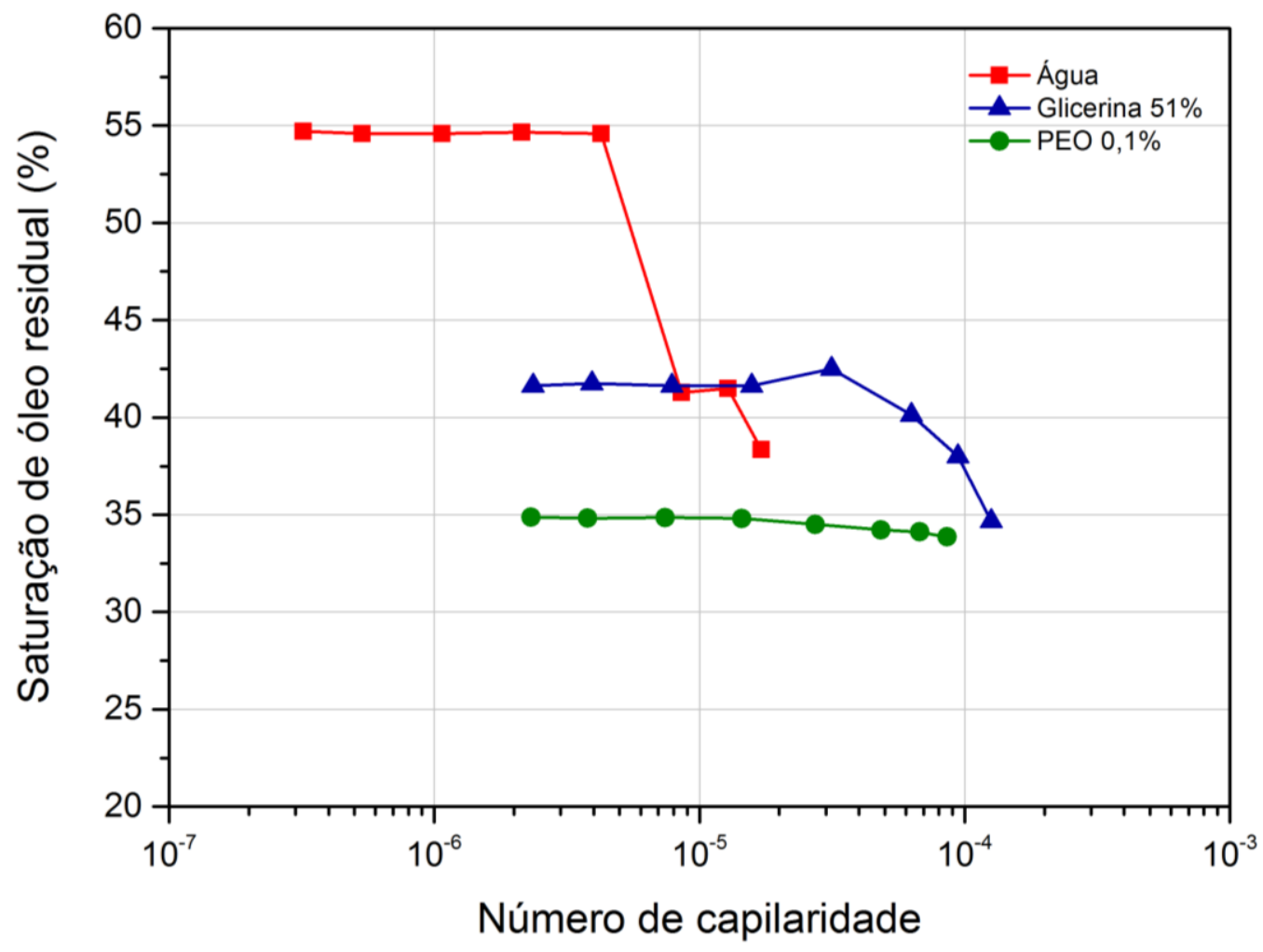

Figura 52 - Saturação de óleo residual em função do número de capilaridade nas regiões ilustradas (A3 e A4)

A saturação média nas regiões A3 e A4 para os diferentes fluidos em função do número de capilaridade é apresentada na Figura 52. Para as menores vazões, observa-se que a saturação residual obtida pela glicerina e PEO é bem menor que a obtida com a injeção de água, mostrando claramente o efeito da razão de mobilidade. Tanto para a água como para a solução de glicerina, observa-se que a saturação residual de óleo é reduzida a partir de um número de capilaridade crítico. Esta redução não é observada no estudo com a injeção da solução de PEO.

Como a condição inicial de cada experimento não era a mesma, foram realizados experimentos com 0 Procedimento 2, conforme explicado anteriormente. 


\section{2.}

\section{Procedimento 2}

Para analisar o comportamento da solução polimérica para uma mesma condição de saturação das fases, foi necessário um novo procedimento experimental, que consistiu em saturar o meio poroso com óleo e injetar a fase aquosa com uma taxa de injeção fixa. Depois o chip foi limpo com álcool etílico, seco, saturado novamente com óleo para que fosse feita uma nova injeção a uma taxa de injeção diferente.

As imagens de cada uma das seis regiões analisadas para as diferentes vazões são apresentadas nas Figuras 53 a 76. As figuras também apresentam a saturação de óleo para cada caso.

Na vazão mais baixa (Fig. 53), a invasão da água é bastante não uniforme. Todo o fluxo segue apenas um caminho, deixando um grande volume de óleo imóvel. Para a glicerina e solução de PEO, que possuem maior viscosidade, um novo caminho da fase aquosa é formado.

É interessante observar que o padrão de ocupação de poros pela glicerina e PEO é praticamente o mesmo, indicando que nestas condições, os efeitos viscosos são dominantes sobre o efeito elástico.

Para $Q=0,52 \mathrm{ml} / \mathrm{h}$ (Fig. 54), observa-se a formação de um segundo caminho na injeção de água. É interessante observar a grande redução na saturação residual de óleo que ocorre no caso de maior vazão e injeção de solução de PEO (Figuras 55 e 56), a saturação residual de óleo cai de 20,9\% para $13,9 \%$ para uma variação de vazão de $Q=2,08 \mathrm{ml} / \mathrm{h}$ para $Q=4,16 \mathrm{ml} / \mathrm{h}$. É importante notar que a saturação residual de óleo no caso da glicerina é reduzida em apenas $1 \%$. Nesta vazão mais alta, o aumento da diferença de pressão da fase aquosa no escoamento através das gargantas de poros causada pela alta viscosidade extensional (efeito elástico) é grande o suficiente para mobilizar os gânglios de óleo.

O comportamento discutido acima se repete para as demais regiões do micromodelo. 


\subsection{1.}

Região A1

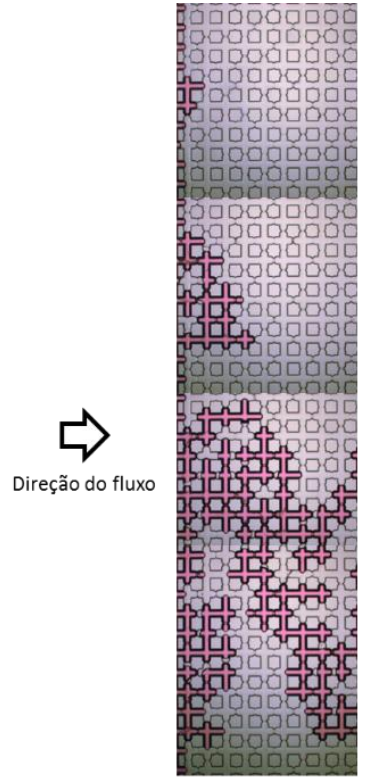

Água

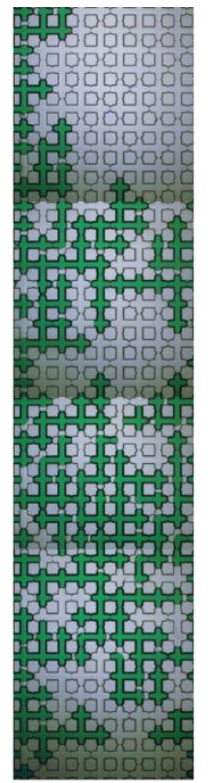

Glicerina

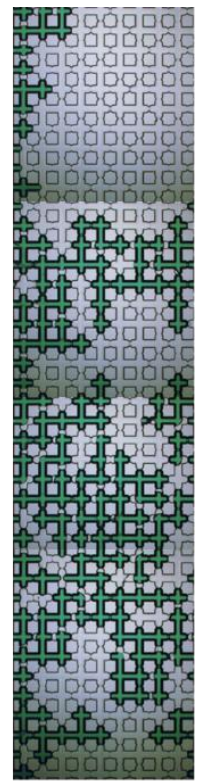

PEO
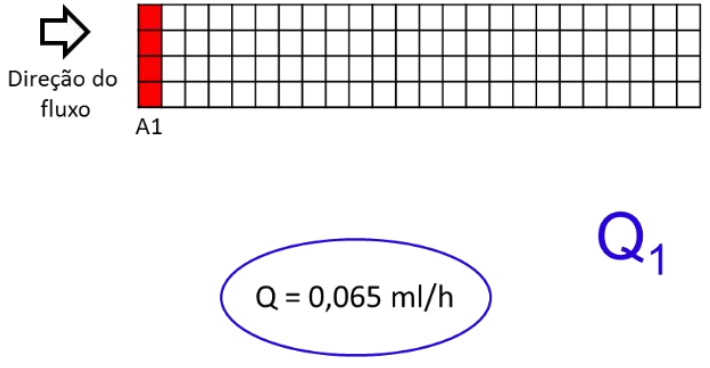

$Q_{1}$
Sor Água = 68,5 \%

Sor Glicerina $=46,5 \%$

Sor PEO = 50,6 \%

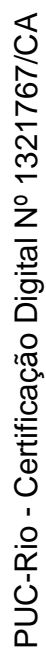

$\mathrm{Ca}=3,9 \times 10^{-6}$

$\mathrm{Ca}=3,7 \times 10^{-6}$

Figura 53 - Perfis de saturação ao final da injeção a 0,065 ml/h na região $A 1$ e as saturações de óleo residual
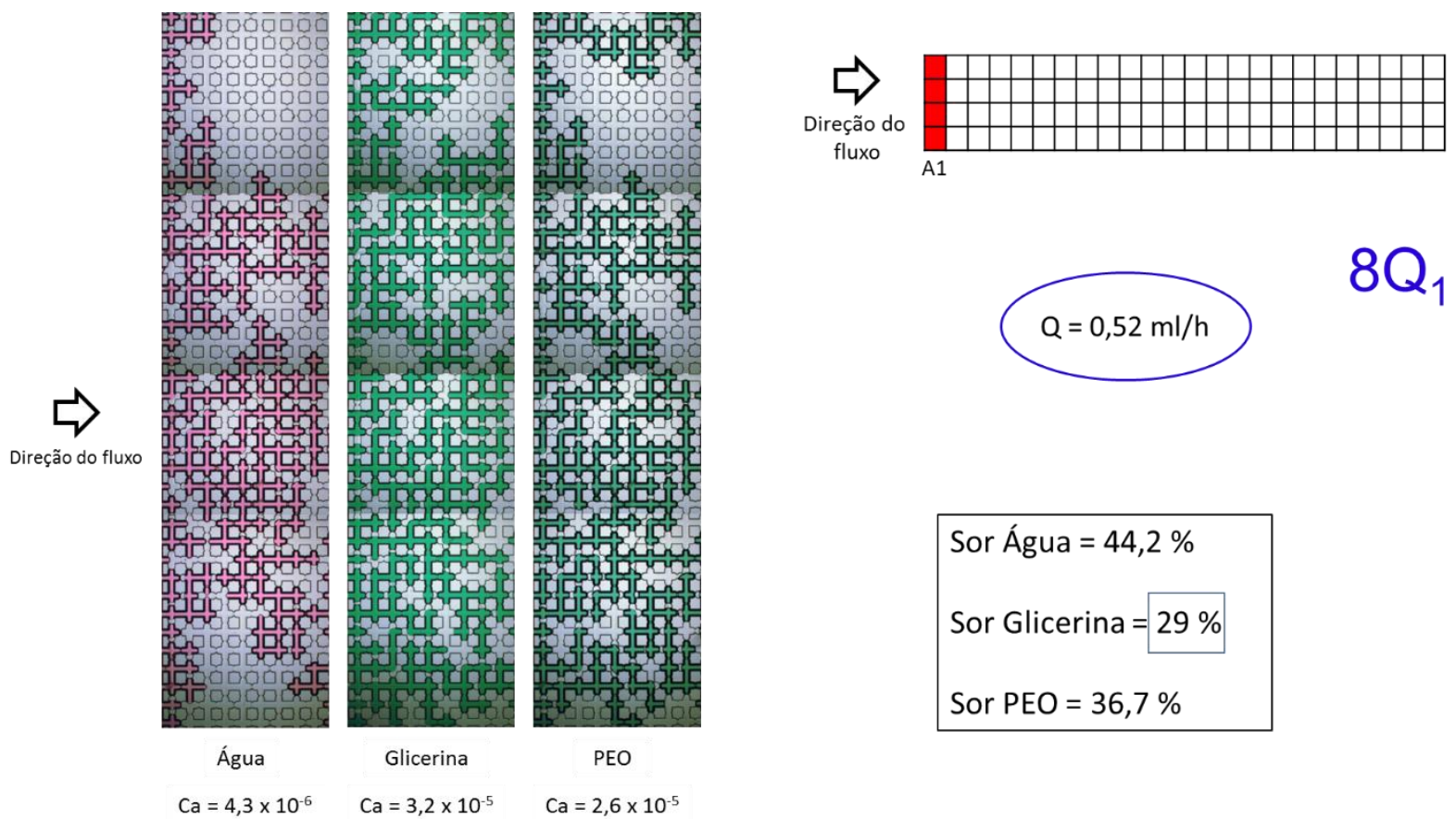

Figura 54 - Perfis de saturação ao final da injeção a 0,52 $\mathrm{ml} / \mathrm{h}$ na região $A 1$ e as saturações de óleo residual 


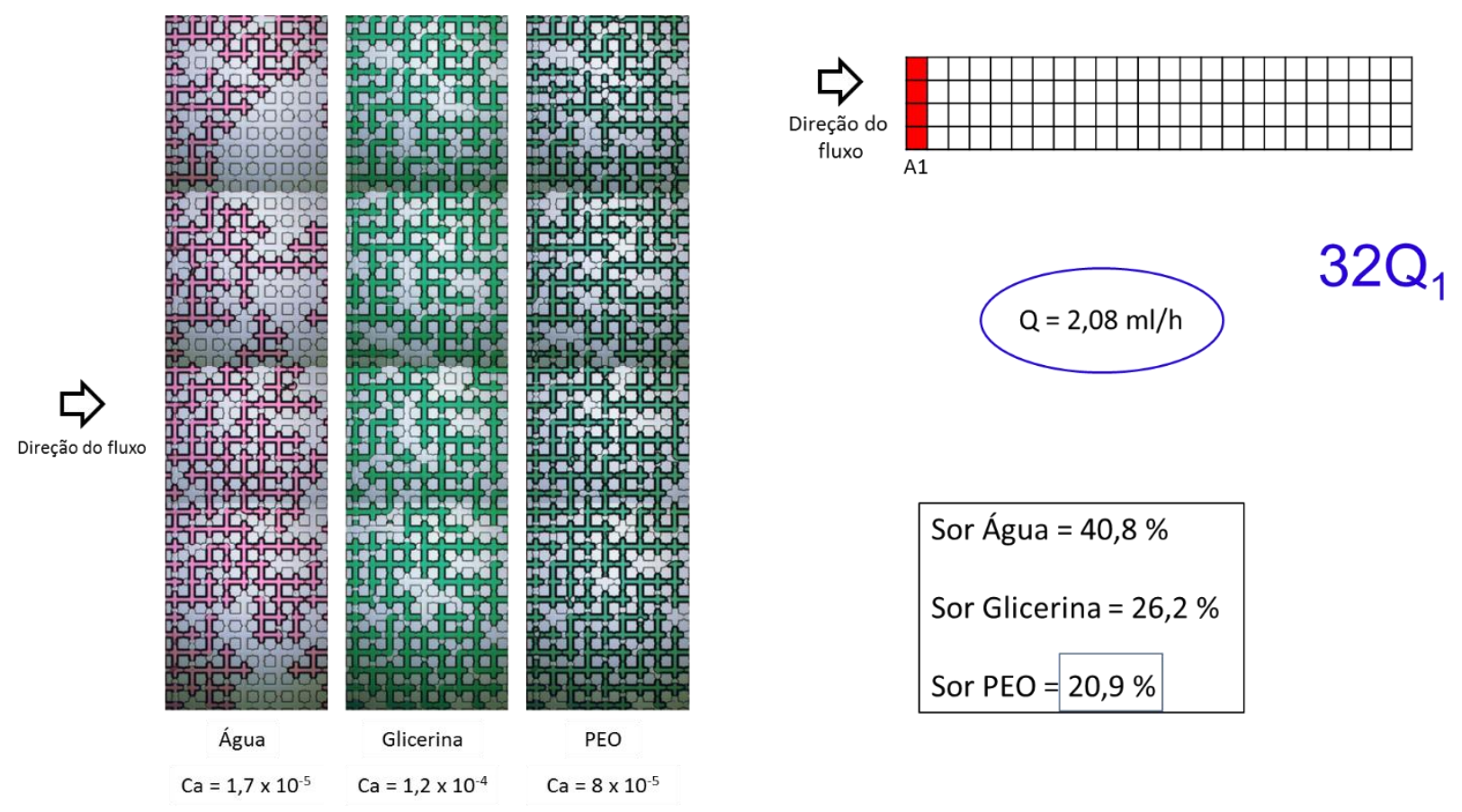

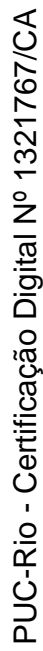

Figura 55 - Perfis de saturação ao final da injeção a $2,08 \mathrm{ml} / \mathrm{h}$ na região A1 e as saturações de óleo residual
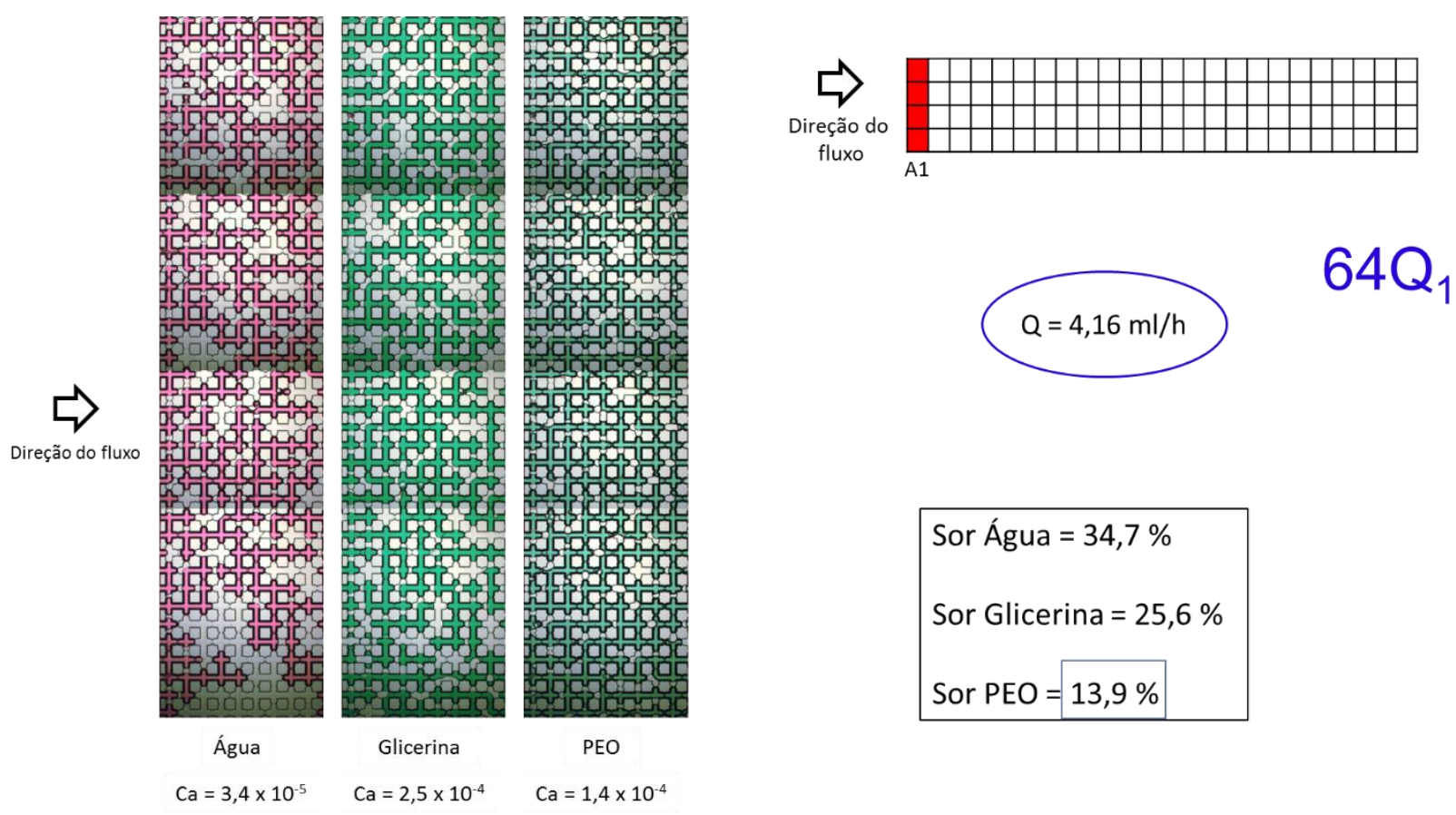

Figura 56 - Perfis de saturação ao final da injeção a 4,16 $\mathrm{ml} / \mathrm{h}$ na região A1 e as saturações de óleo residual 


\subsection{2.}

Região A2

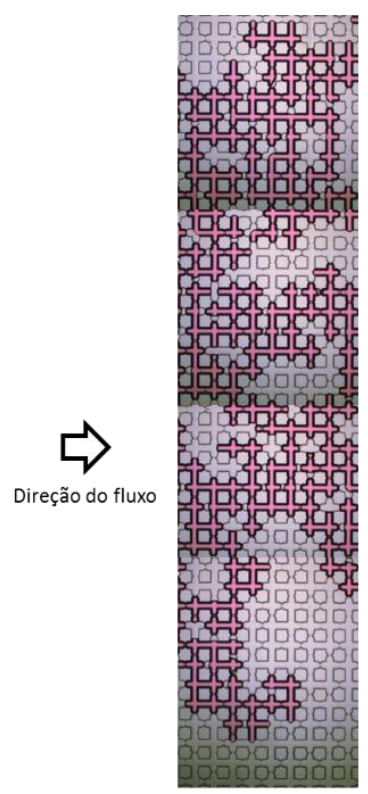

Água

$\mathrm{Ca}=5,3 \times 10^{-7}$

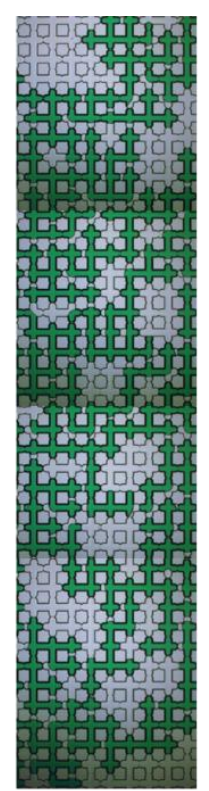

Glicerina

$\mathrm{Ca}=3,9 \times 10^{-6}$

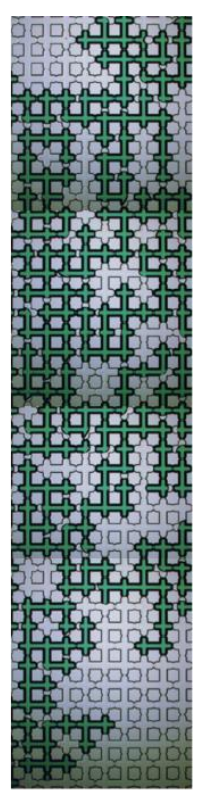

PEO

$\mathrm{Ca}=3,7 \times 10^{-6}$
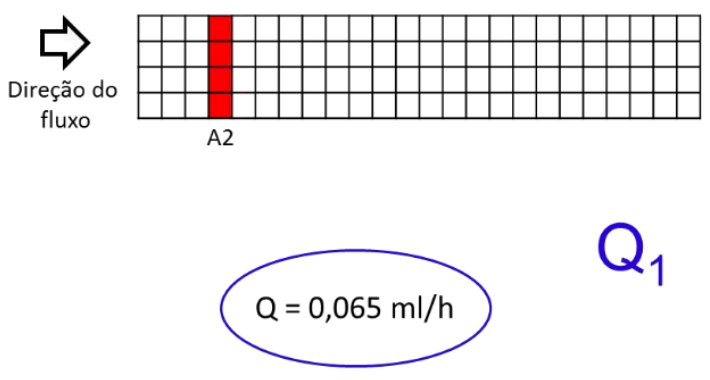

$Q_{1}$
Sor Água $=44,5 \%$

Sor Glicerina $=32,5 \%$

Sor PEO $=36,3 \%$

Figura 57 - Perfis de saturação ao final da injeção a $0,065 \mathrm{ml} / \mathrm{h}$ na região $A 2$ e as saturações de óleo residual
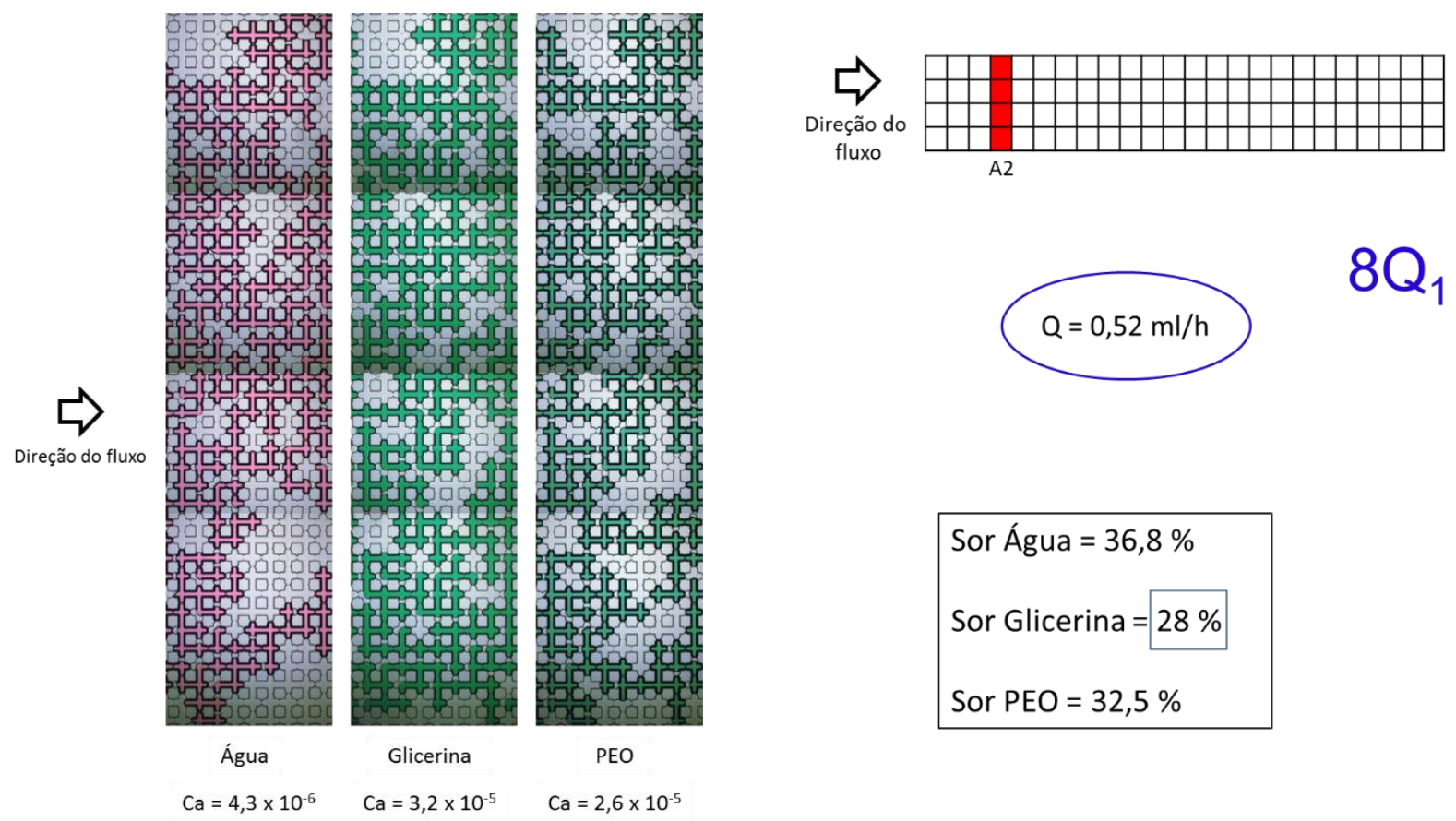

Figura 58 - Perfis de saturação ao final da injeção a 0,52 $\mathrm{ml} / \mathrm{h}$ na região $A 2$ e as saturações de óleo residual 


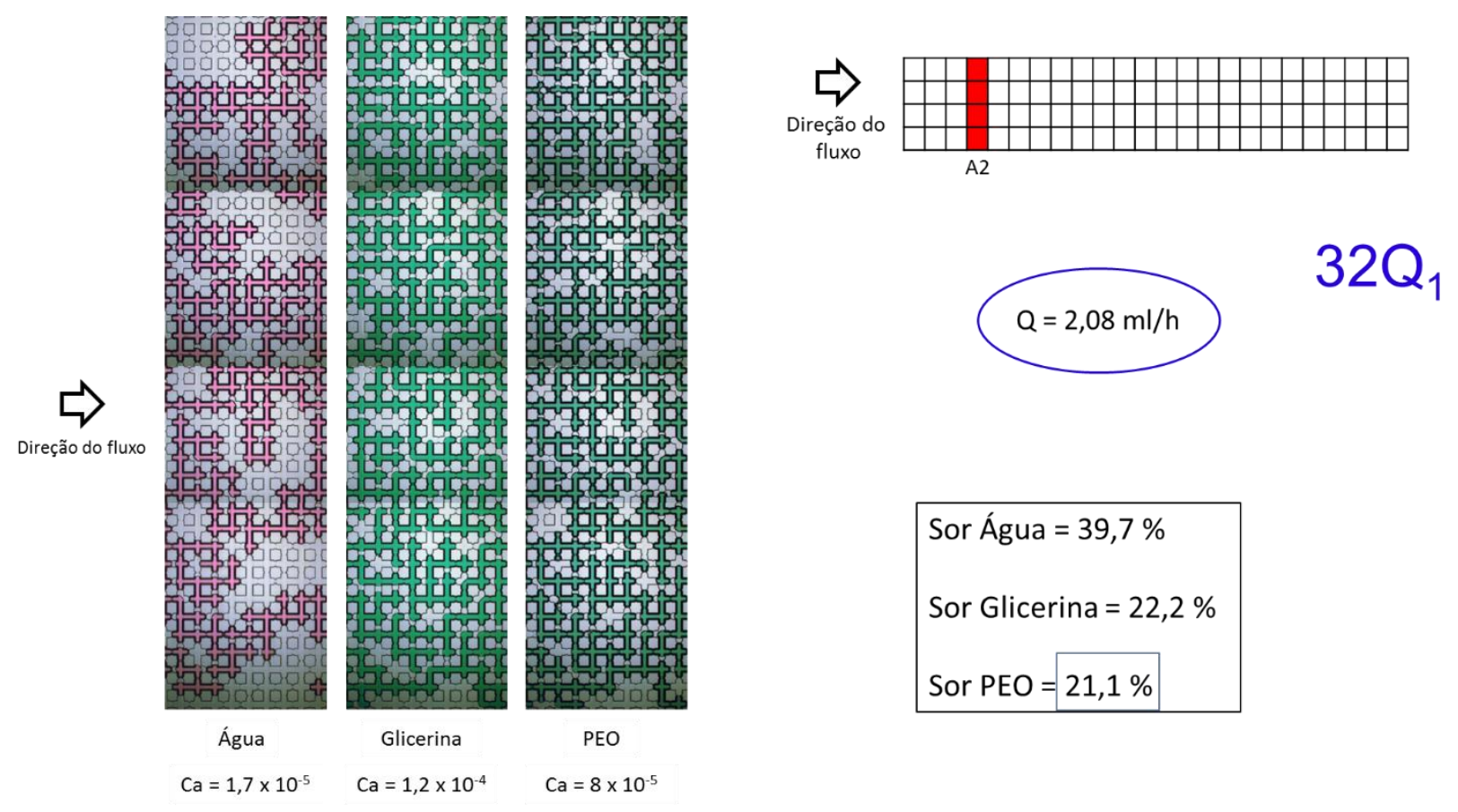

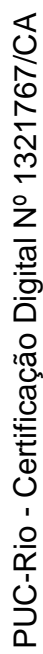

Figura 59 - Perfis de saturação ao final da injeção a $2,08 \mathrm{ml} / \mathrm{h}$ na região $\mathrm{A2}$ e as saturações de óleo residual
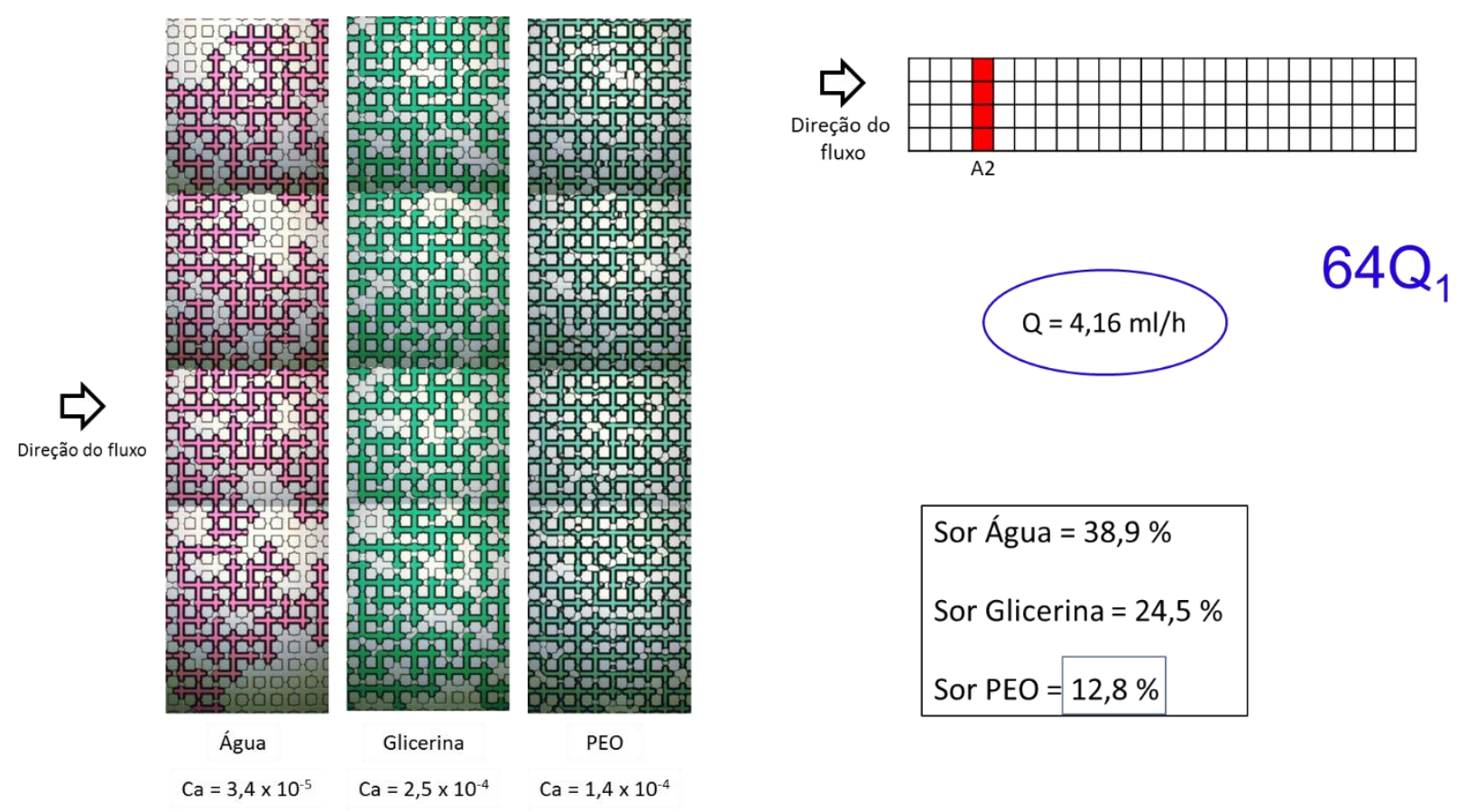

Figura 60 - Perfis de saturação ao final da injeção a 4,16 ml/h na região A2 e as saturações de óleo residual 


\subsection{3.}

\section{Região A3}

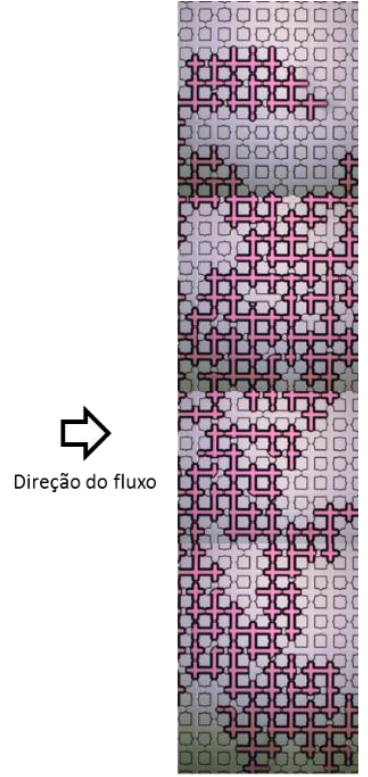

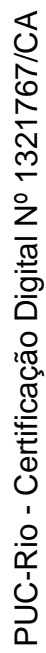

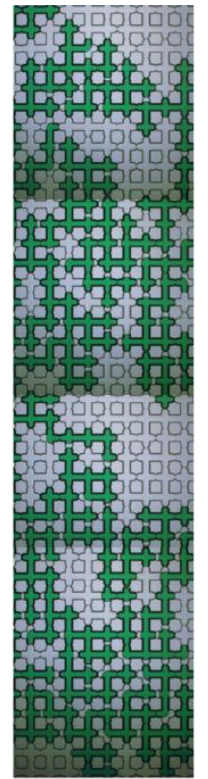

Glicerina

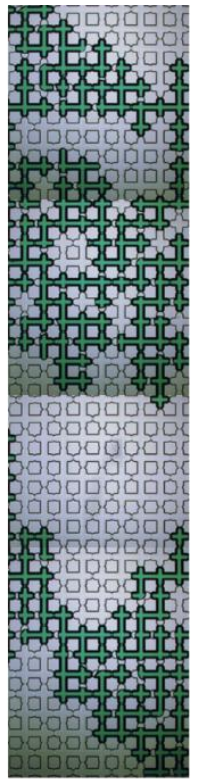

PEO
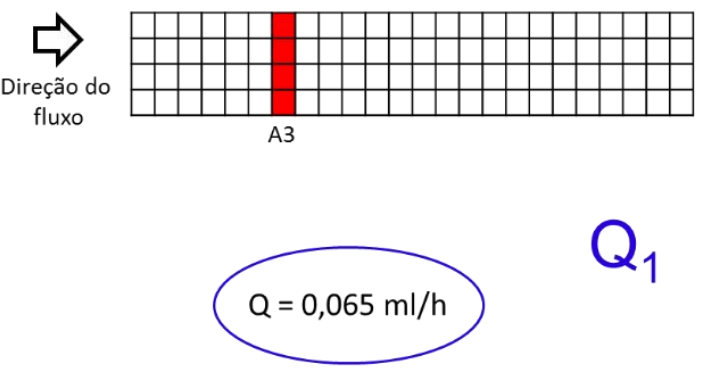

$Q_{1}$

Sor Água $=43,9 \%$

Sor Glicerina $=39,5 \%$

Sor PEO $=51,4 \%$

Figura 61 - Perfis de saturação ao final da injeção a 0,065 ml/h na região A3 e as saturações de óleo residual
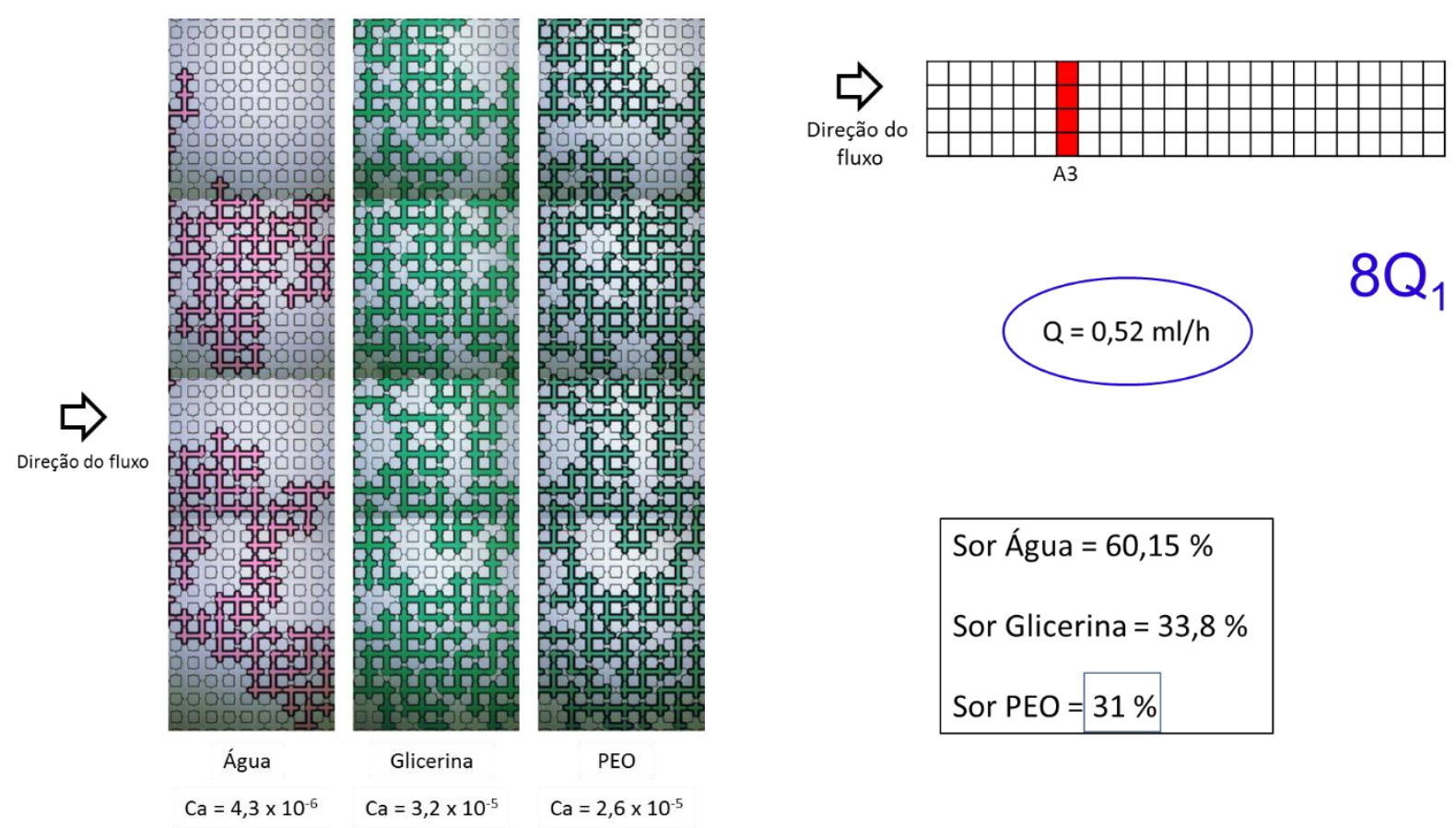

Figura 62 - Perfis de saturação ao final da injeção a 0,52 $\mathrm{ml} / \mathrm{h}$ na região $A 3$ e as saturações de óleo residual 


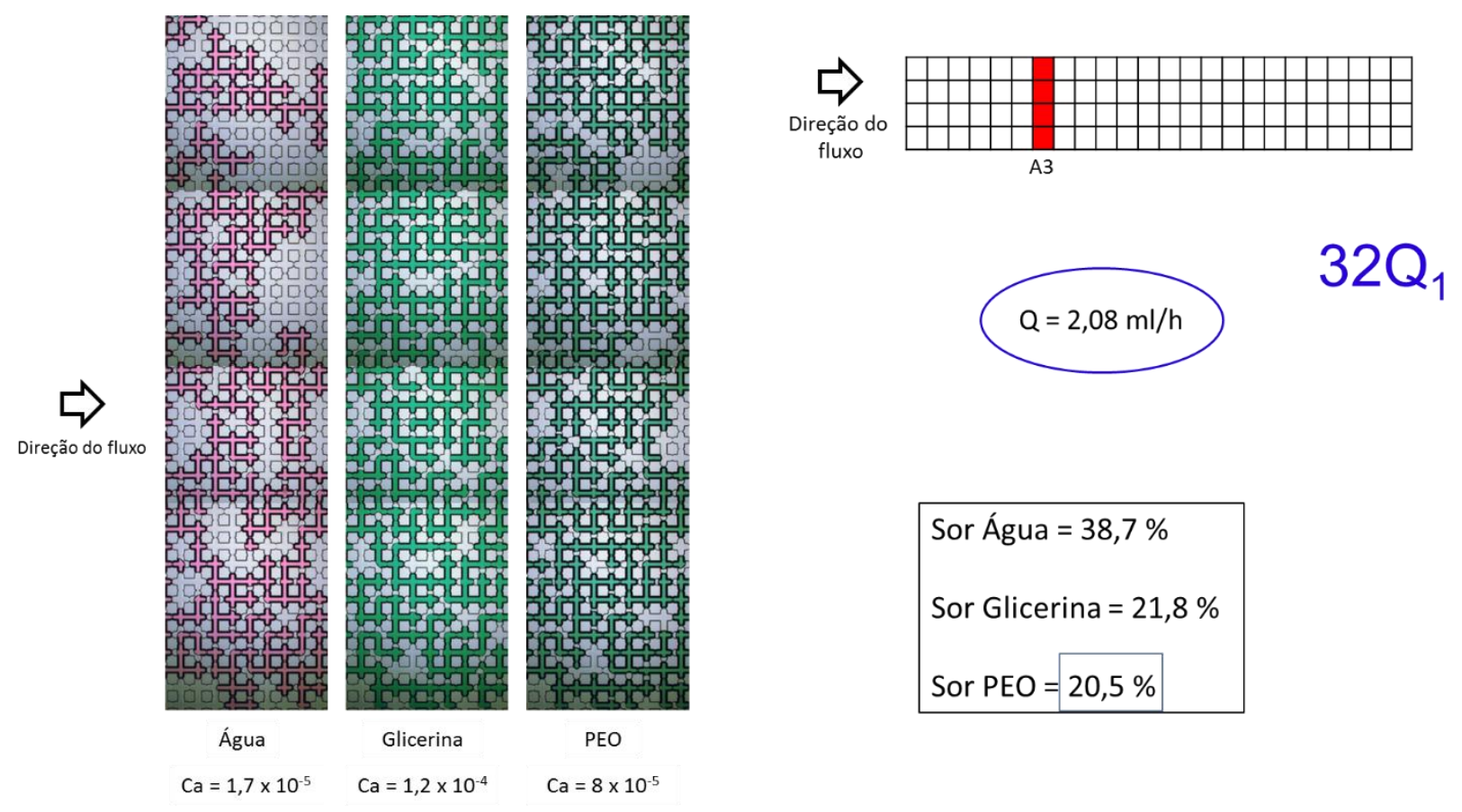

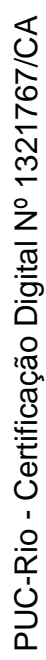

Figura 63 - Perfis de saturação ao final da injeção a $2,08 \mathrm{ml} / \mathrm{h}$ na região $A 3$ e as saturações de óleo residual
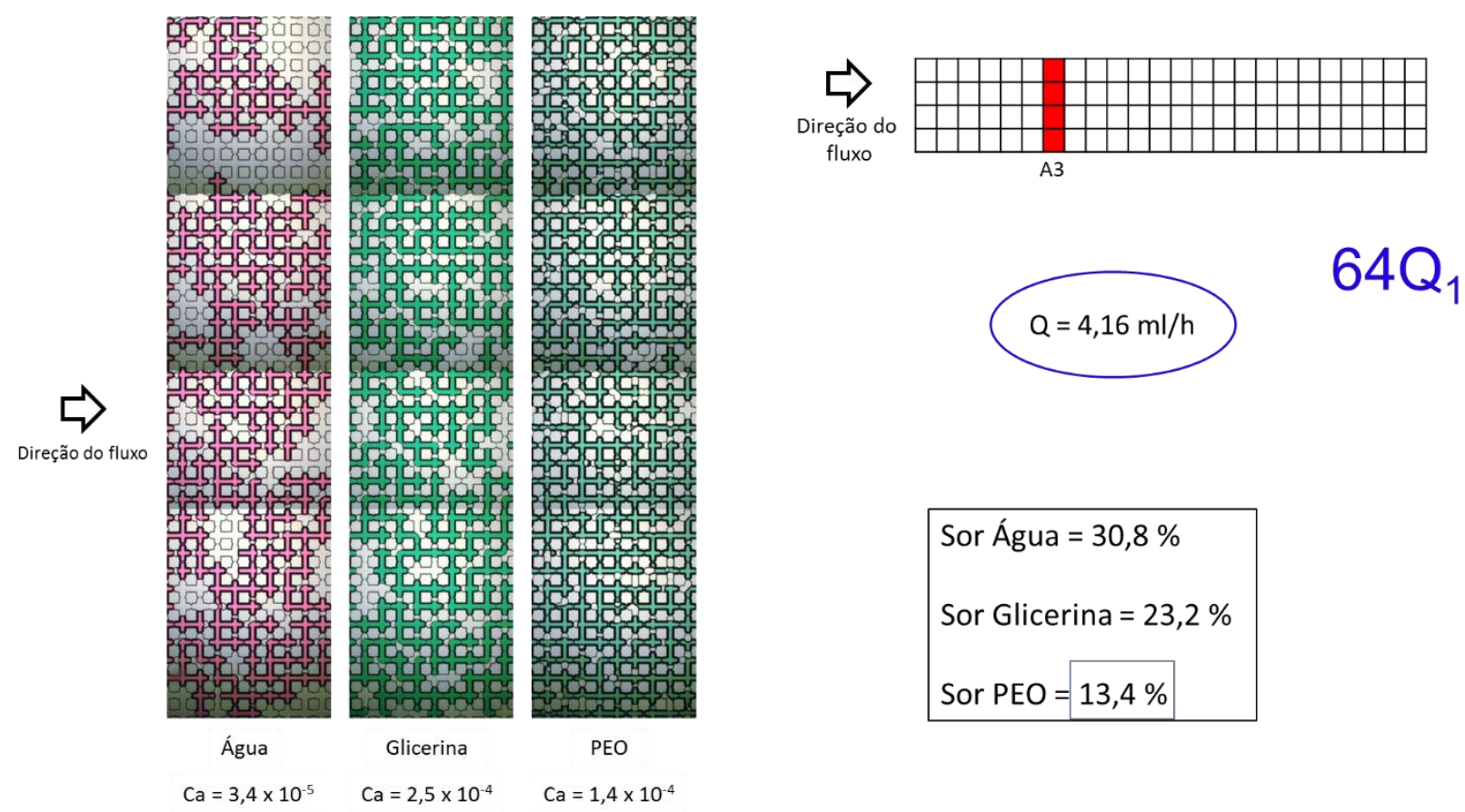

Figura 64 - Perfis de saturação ao final da injeção a 4,16 $\mathrm{ml} / \mathrm{h}$ na região $A 3$ e as saturações de óleo residual 
3.2.4.

Região A4

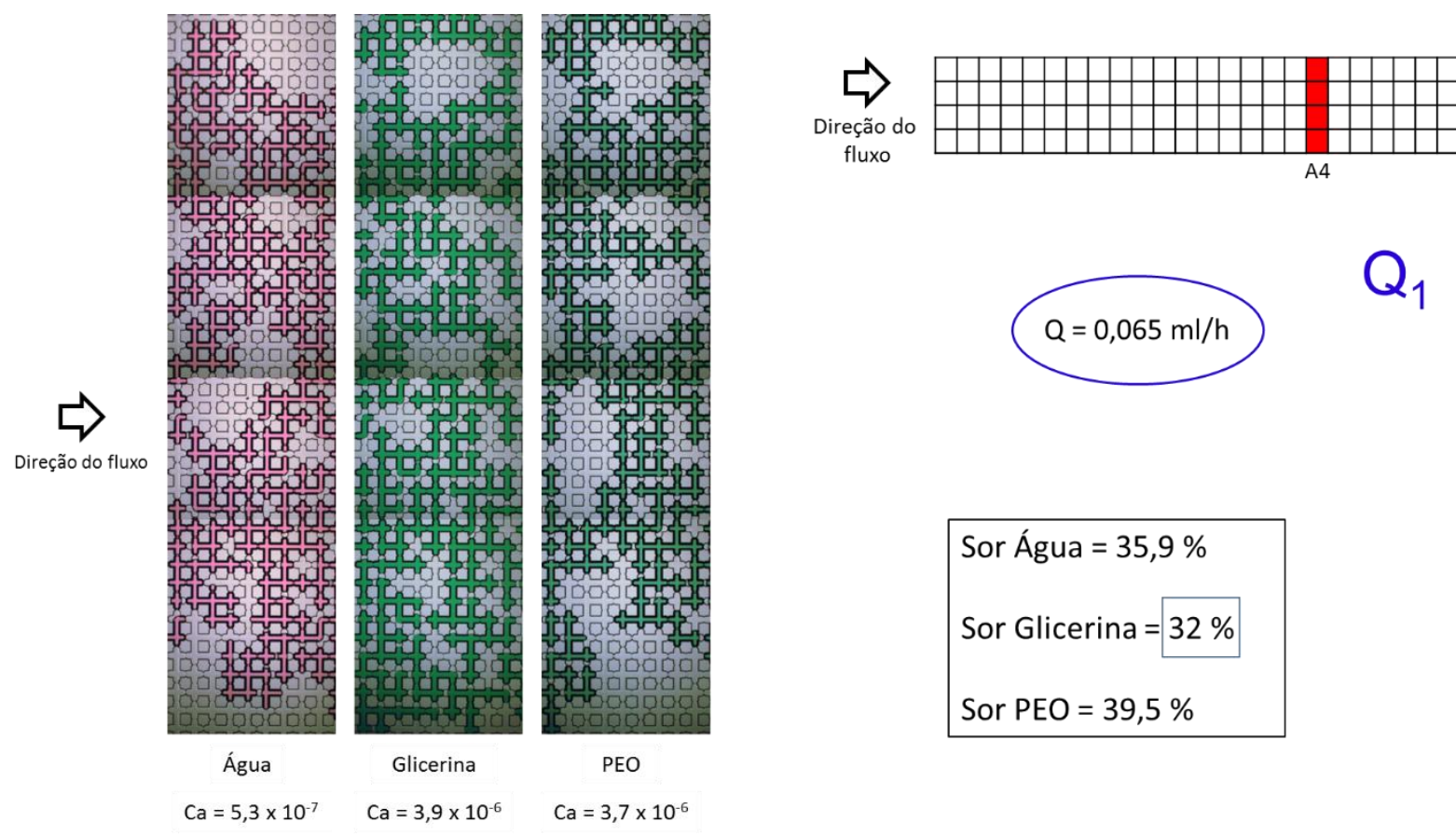

Figura 65 - Perfis de saturação ao final da injeção a 0,065 ml/h na região A4 e as saturações de óleo residual
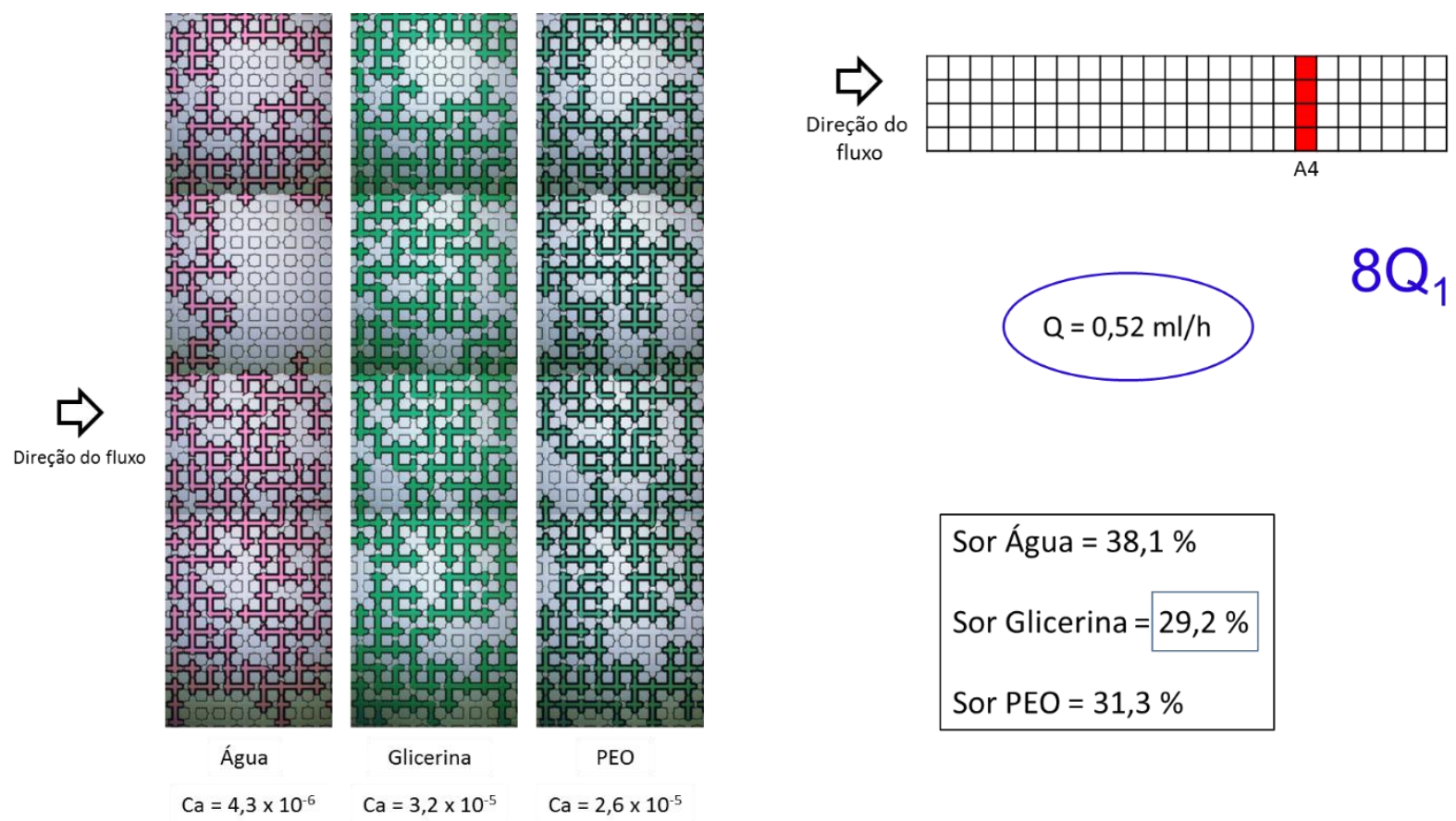

Figura 66 - Perfis de saturação ao final da injeção a 0,52 $\mathrm{ml} / \mathrm{h}$ na região A4 e as saturações de óleo residual 


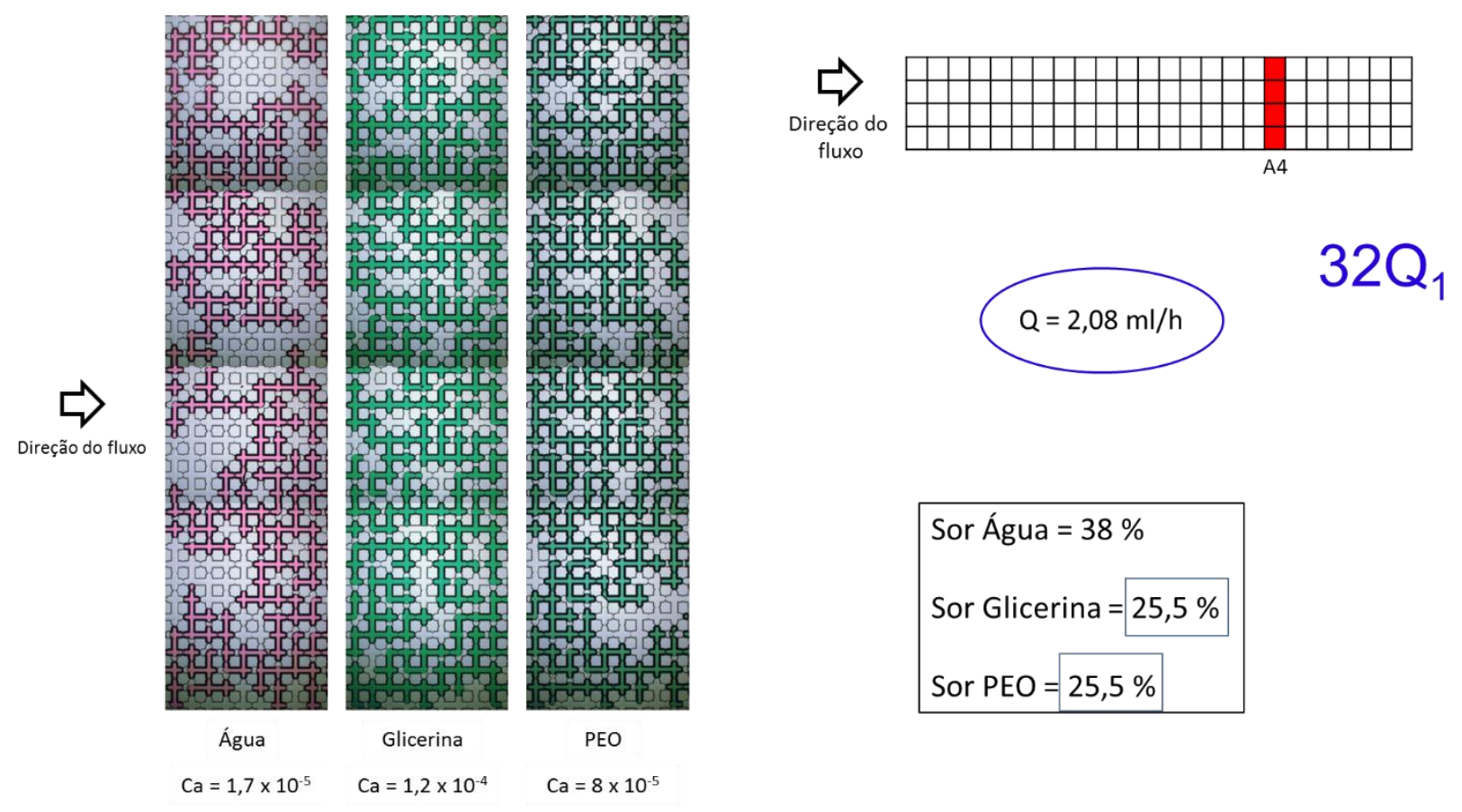

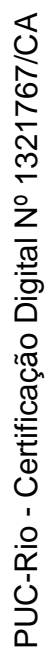

Figura 67 - Perfis de saturação ao final da injeção a $2,08 \mathrm{ml} / \mathrm{h}$ na região $\mathrm{A4}$ e as saturações de óleo residual

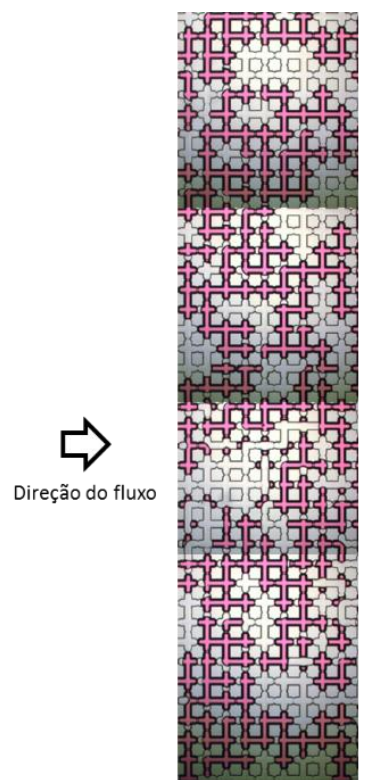

Água $\mathrm{Ca}=3,4 \times 10^{-5}$

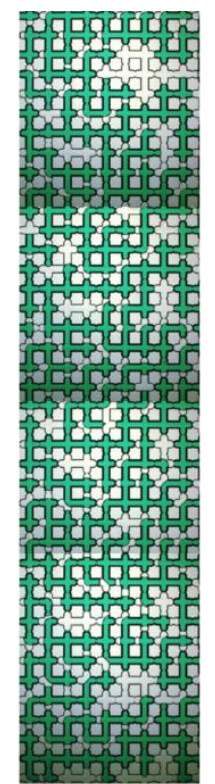

Glicerina

$\mathrm{Ca}=2,5 \times 10^{-4}$

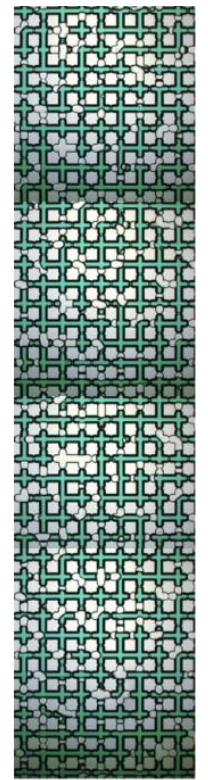

PEO

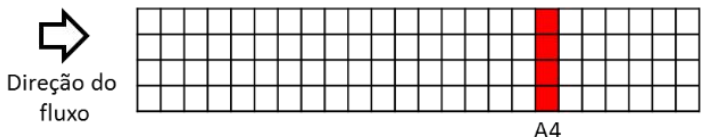

$64 Q_{1}$

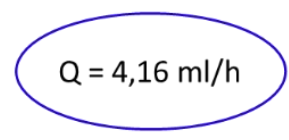

Sor Água = 37,2 \%
Sor Glicerina = 22,4 \%
Sor PEO = $15,5 \%$

$\mathrm{Ca}=1,4 \times 10^{-4}$

Figura 68 - Perfis de saturação ao final da injeção a 4,16 $\mathrm{ml} / \mathrm{h}$ na região $A 4$ e as saturações de óleo residual 
3.2.5.

\section{Região A5}

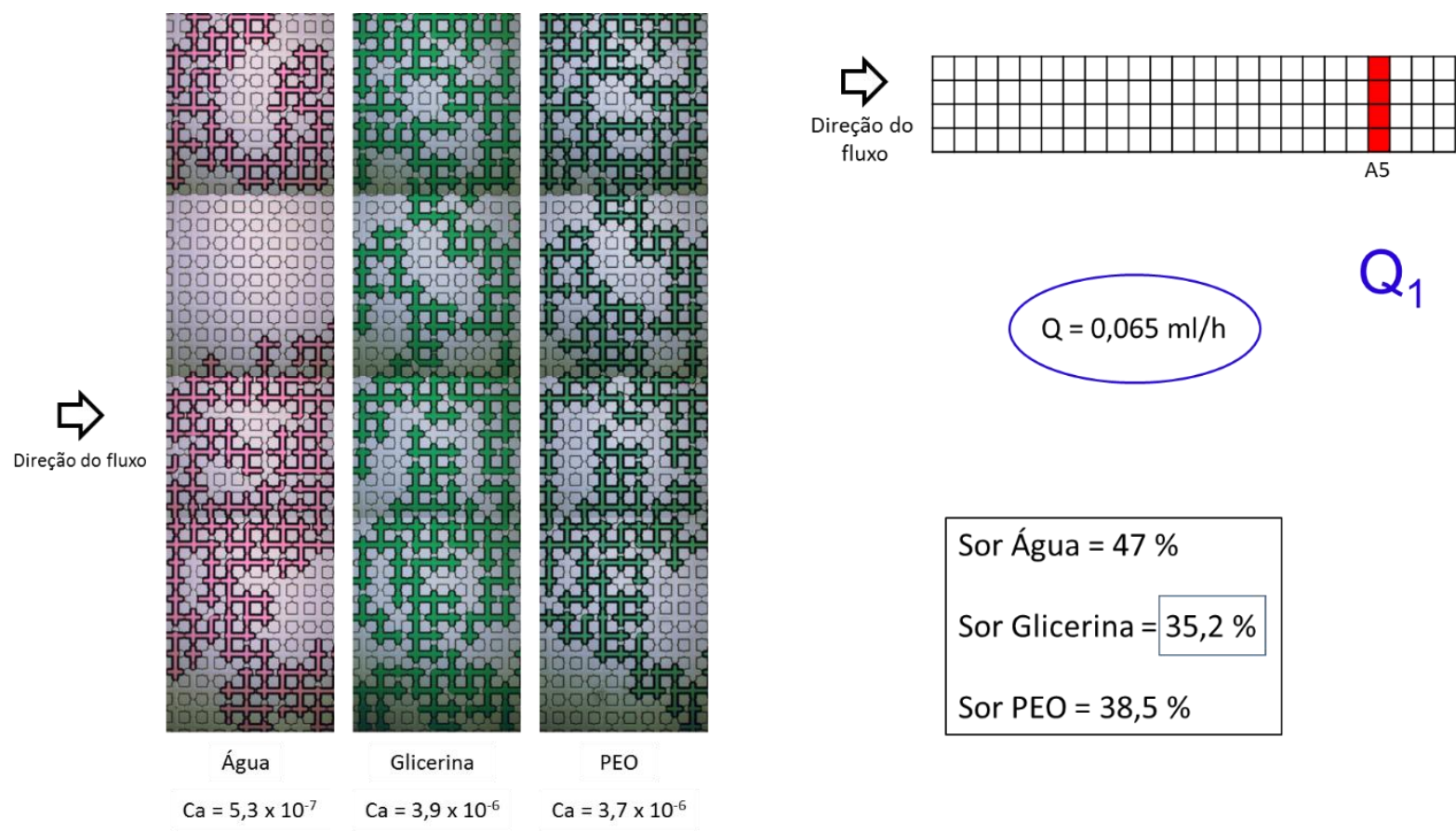

Figura 69 - Perfis de saturação ao final da injeção a 0,065 ml/h na região A5 e as saturações de óleo residual
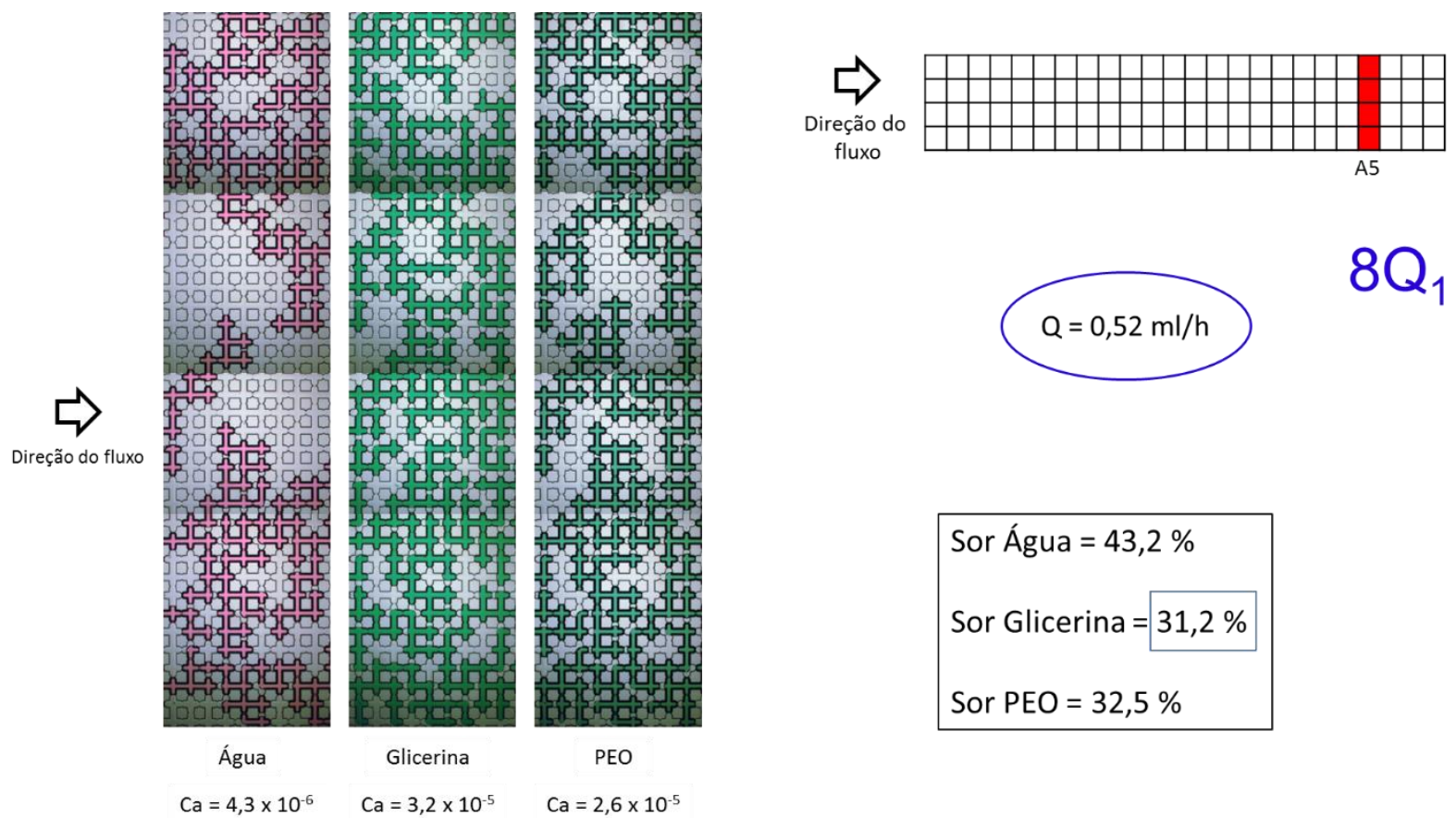

Figura 70 - Perfis de saturação ao final da injeção a $0,52 \mathrm{ml} / \mathrm{h}$ na região $A 5$ e as saturações de óleo residual 


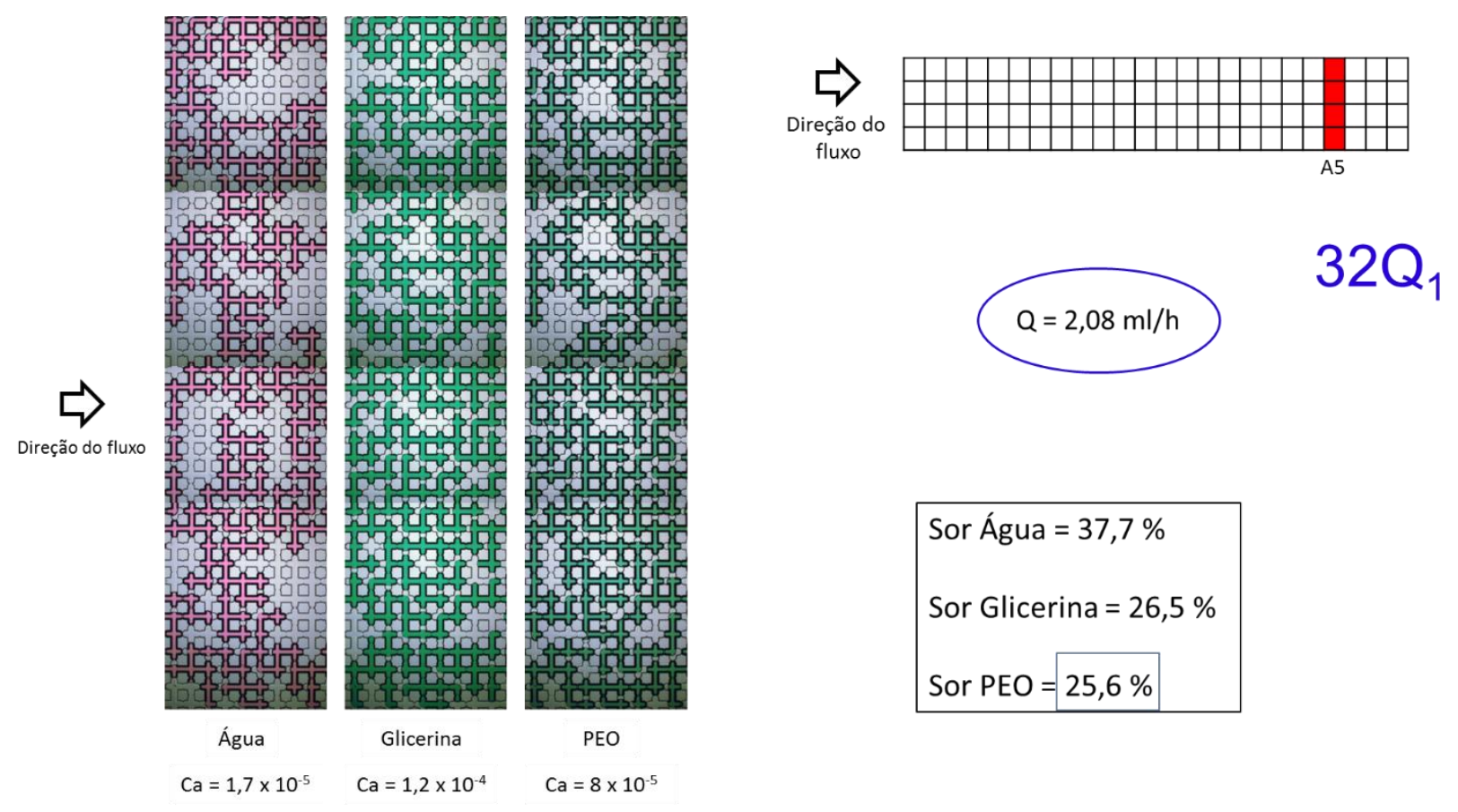

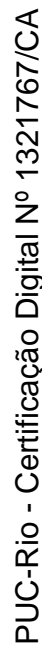

Figura 71 - Perfis de saturação ao final da injeção a 2,08 $\mathrm{ml} / \mathrm{h}$ na região $A 5$ e as saturações de óleo residual

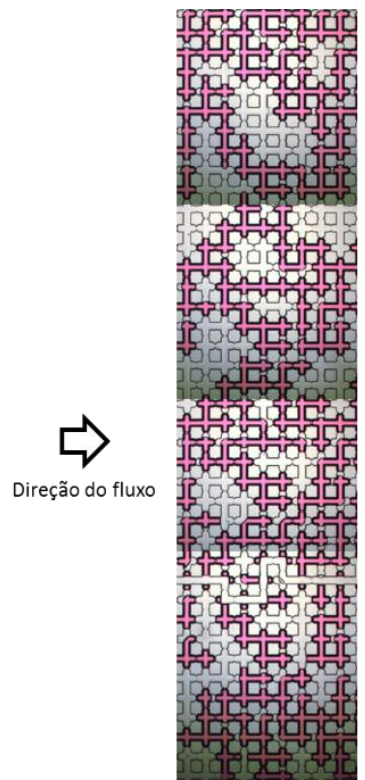

Água

$\mathrm{Ca}=3,4 \times 10^{-5}$

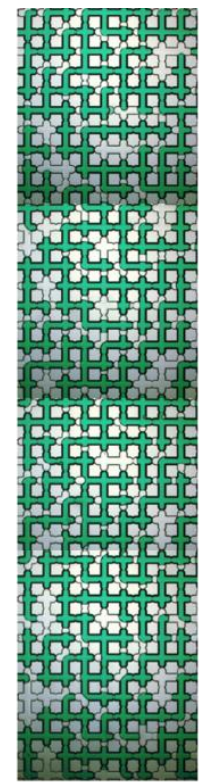

Glicerina

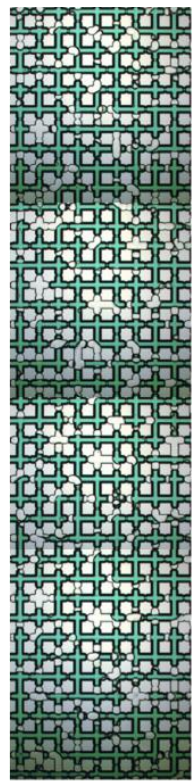

PEO

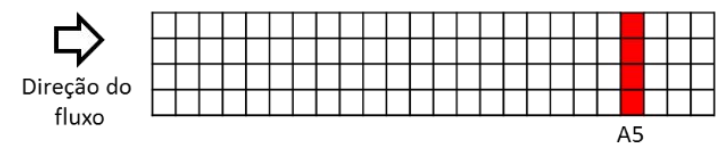

$64 Q_{1}$

Sor Água $=40,5 \%$

Sor Glicerina $=22,3 \%$

Sor PEO $=16,6 \%$

Figura 72 - Perfis de saturação ao final da injeção a 4,16 $\mathrm{ml} / \mathrm{h}$ na região $A 5$ e as saturações de óleo residual 


\subsection{6.}

Região A6

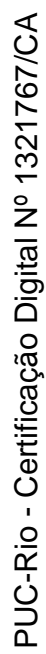

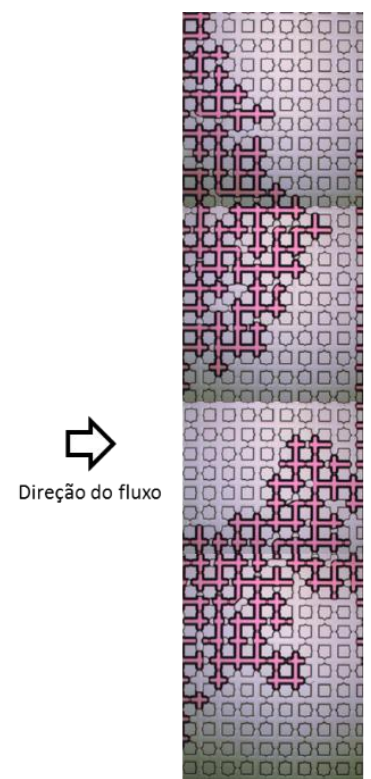

Água

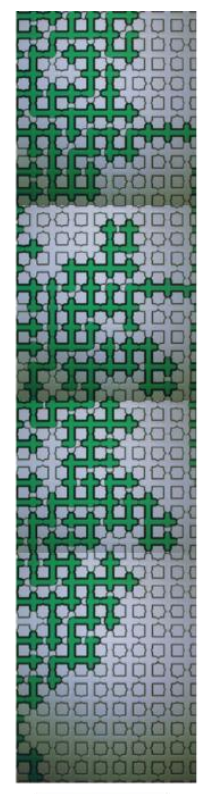

Glicerina

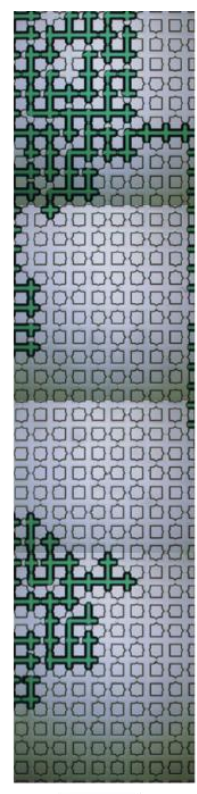

PEO

$\mathrm{Ca}=5,3 \times 10^{-7}$

$\mathrm{Ca}=3,9 \times 10^{-6}$

$\mathrm{Ca}=3,7 \times 10^{-6}$
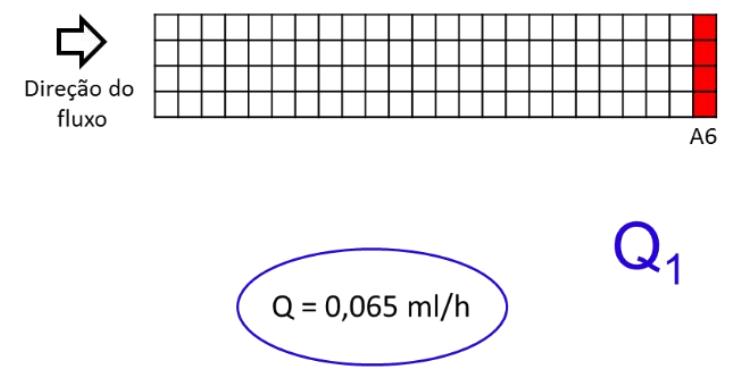

$Q_{1}$

Figura 73 - Perfis de saturação ao final da injeção a $0,065 \mathrm{ml} / \mathrm{h}$ na região $A 6$ e as saturações de óleo residual

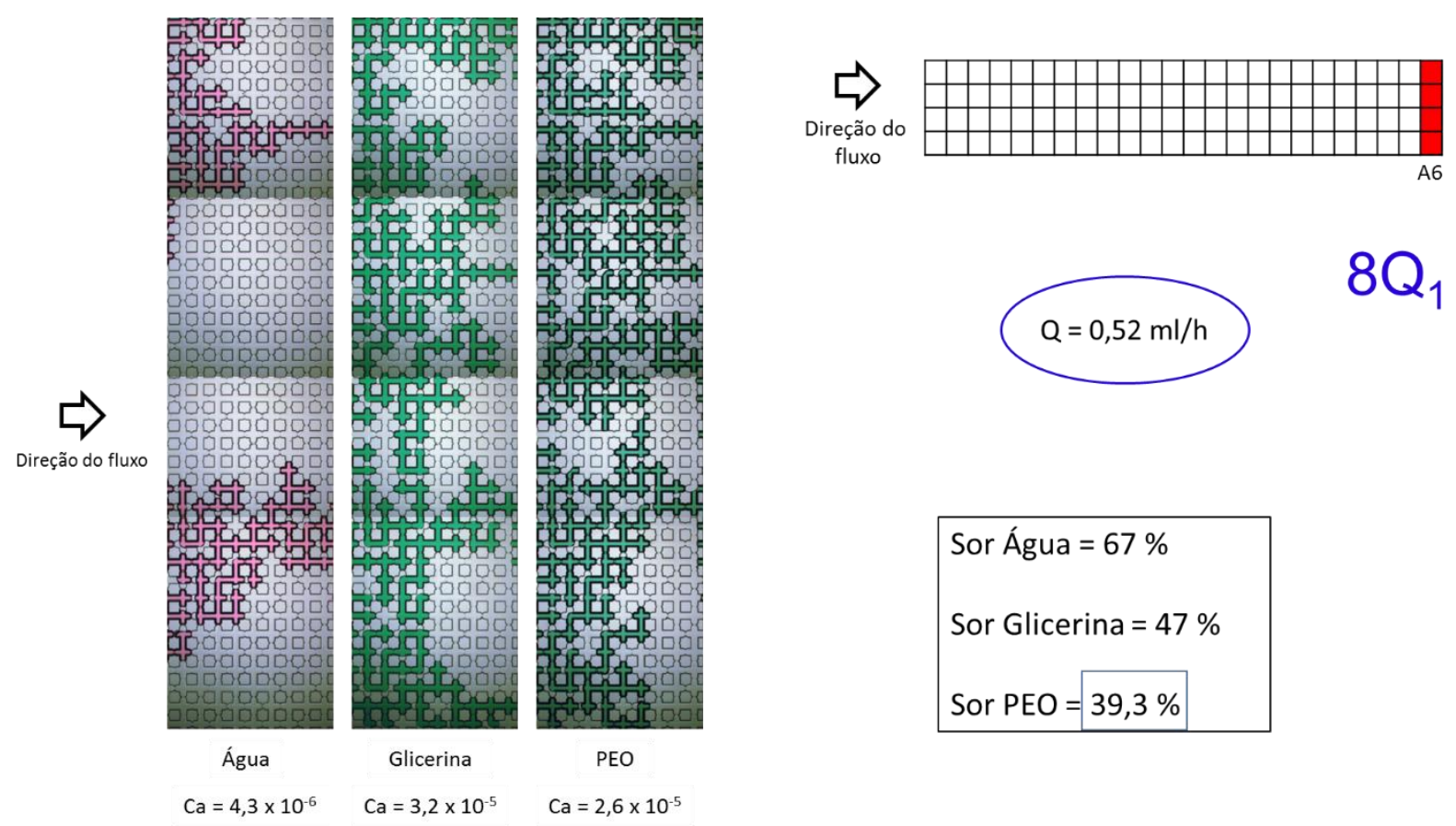

Figura 74 - Perfis saturação ao final da injeção a $0,52 \mathrm{ml} / \mathrm{h}$ na região $A 6$ e as saturações de óleo residual 


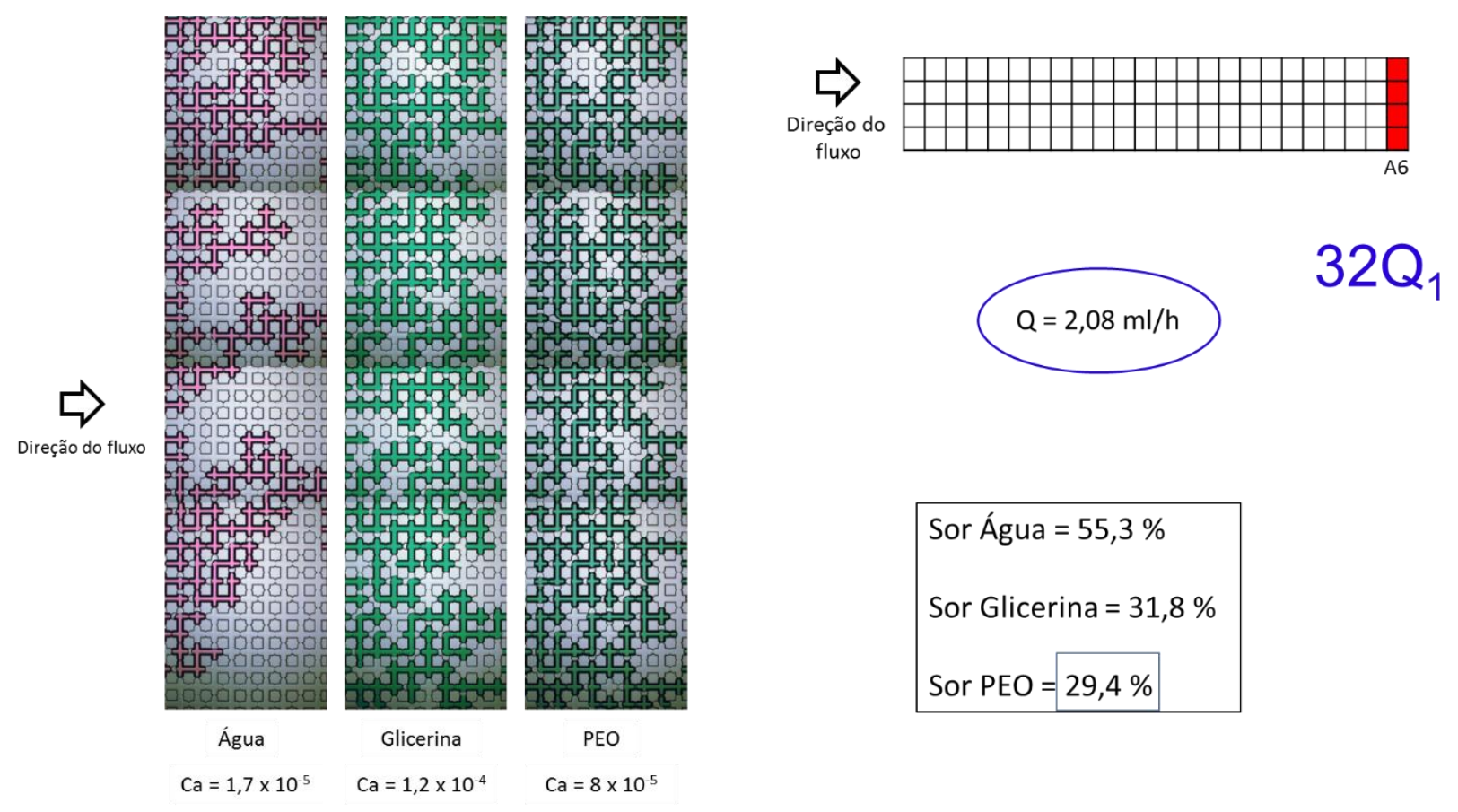

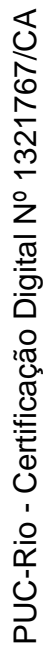

Figura 75 - Perfis de saturação ao final da injeção a 2,08 ml/h na região A6 e as saturações de óleo residual

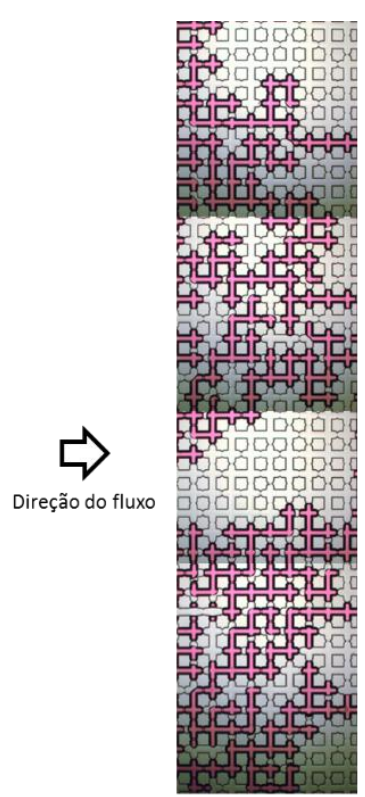

Água

$\mathrm{Ca}=3,4 \times 10^{-5}$

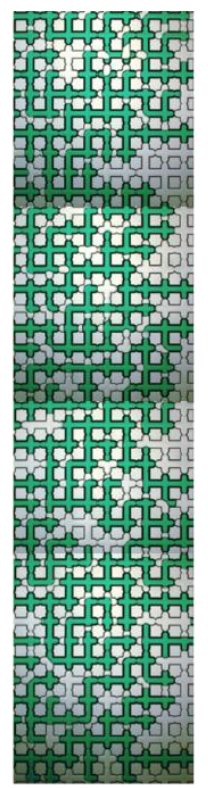

Glicerina

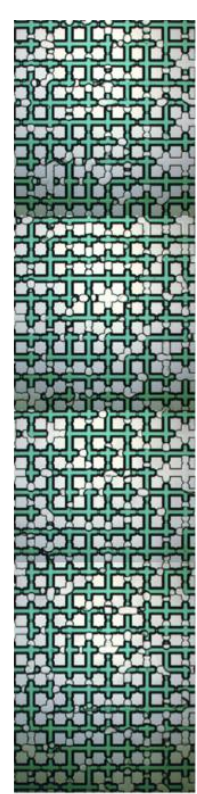

PEO

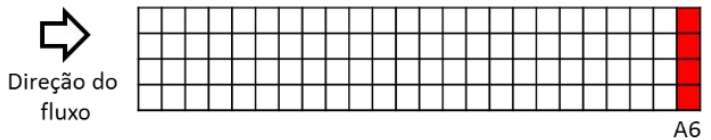

$64 Q_{1}$

Figura 76 - Perfis de saturação ao final da injeção a 4,16 $\mathrm{ml} / \mathrm{h}$ na região $A 6$ e as saturações de óleo residual 
Analisando as imagens dos testes experimentais e os valores de saturação de óleo residual calculados com o MATLAB (Figuras 53 a 76) foi possível perceber que para as taxas de injeções mais baixas, a solução de glicerina deslocou melhor o óleo no interior do meio poroso, alcançando menores valores de Sor. No entanto, com o aumento da taxa de injeção, a solução de PEO apresentou melhores resultados, recuperando mais óleo que a água e a solução de glicerina.

Os efeitos elásticos aumentam a diferença de pressão da fase aquosa, levando a formação de gânglios de óleo menores. Estes efeitos só ocorrem se a taxa de extensão for alta o suficiente levando a um alto valor da viscosidade extensional. Por isso, esse efeito só é observado na vazão mais alta. A Figura 77 mostra as imagens da região A4 para a maior vazão. Os gânglios grandes foram marcados com a cor amarela e gânglios médios com a cor azul. É possível perceber que ao final da injeção com soluções poliméricas observa-se somente poucos gânglios médios, diferente do que ocorre na injeção de água e solução de glicerina. 

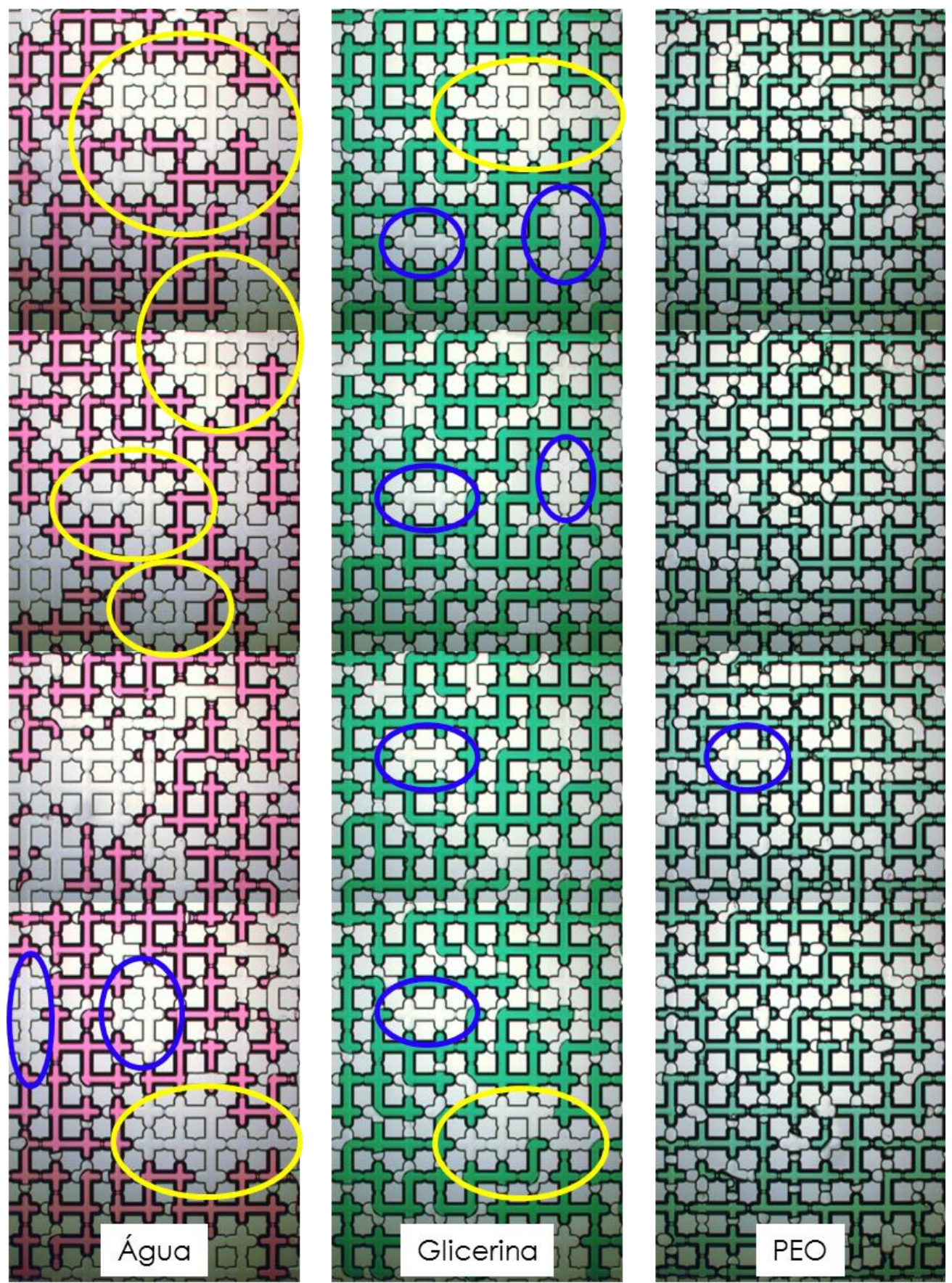

Figura 77 - Gânglios de óleo (Procedimento 2 - taxa de injeção de 4,16 ml/h região A4) 


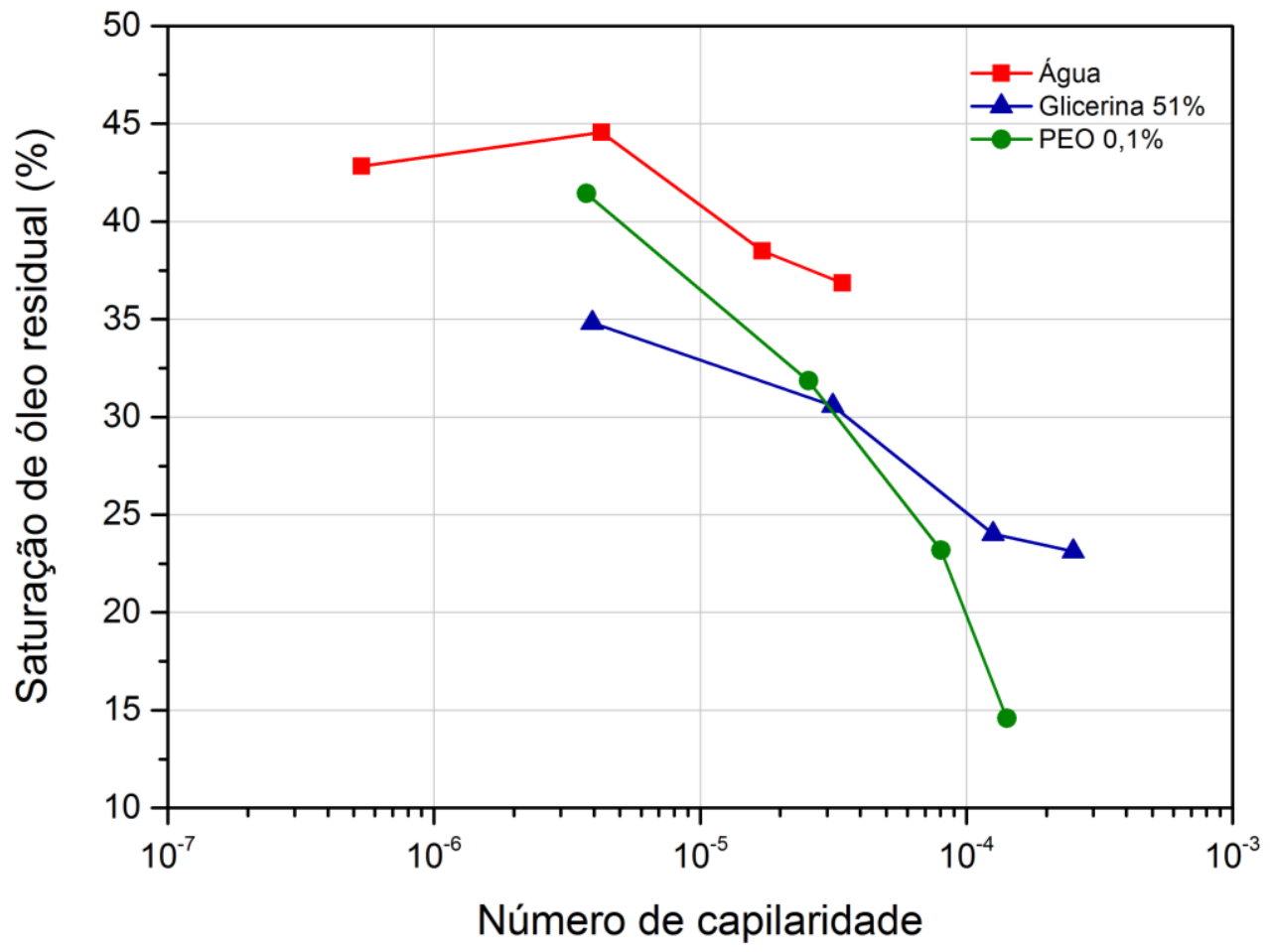

Figura 78 - Gráfico da saturação de óleo residual em função do número de capilaridade para as três fases aquosas

As saturações médias de todas as regiões em função do número de capilaridade para as três fases aquosas testadas são apresentadas na Figura 78. Uma primeira observação importante é que as curvas apresentadas na Figura 78 são bem diferentes das curvas apresentadas na Figura 52, o que mostra a importância da condição inicial do experimento para a determinação da saturação residual de óleo. Para números de capilaridade muito baixos, a saturação residual não depende fortemente da vazão (número de capilaridade).

Comparando as curvas para os dois fluidos Newtonianos testados, observase, como esperado, que a saturação residual de óleo é menor no caso da injeção de solução de glicerina. A maior viscosidade leva a diferenças de pressão maiores na fase aquosa, contribuindo para mobilização de gânglios de óleo e consequente redução na saturação residual de óleo. Na vazão mais baixa, a saturação residual de óleo obtida na injeção da solução polimérica foi mais alta do que a solução de glicerina, apesar dos dois fluidos terem viscosidades semelhantes. Não se sabe explicar o porquê, porém vale observar que a saturação na região A6 com a solução de PEO foi extremamente alta (aproximadamente 75\%), contribuindo para este alto valor. Alguma aglomeração de moléculas poliméricas mal dissolvidas 
pode ter obstruído alguns dos canais, levando a formação de somente um caminho da fase aquosa para o plano de saída, como mostrado na Figura 73.

A medida que a vazão aumenta, a saturação de óleo decai para todos os casos. As forças viscosas mais fortes levam à formação de gânglios de óleo menores, diminuindo desta forma a saturação residual de óleo. Porém, no caso da solução de PEO, a queda de saturação residual de óleo é muito mais forte nas duas maiores vazões, atingindo um valor próximo de 15\%, muito menor do que o valor de $25 \%$, obtido com a injeção de glicerina.

Para altas vazões, onde a taxa de deformação é maior que 100 1/s, o efeito shear thinning torna o efeito elástico ainda mais forte, pois existe uma pequena diferença entre a viscosidade do PEO e a da solução de glicerina.

Esta redução pode ser diretamente relacionada aos efeitos elásticos, presentes no escoamento da solução de PEO, mas ausente no escoamento de glicerina. 


\section{4 \\ Comentários finais}

As soluções poliméricas são utilizadas na indústria do petróleo como método avançado de recuperação, com o objetivo de aumentar a produção de óleo comparado com a injeção de água.

A relativa baixa eficiência da injeção de água está relacionada a dois fenômenos principais, a não uniformidade da frente de avanço devido à alta razão de mobilidade entre a água e o óleo, e ao alto valor da saturação residual de óleo, relacionado ao volume de óleo preso pelos efeitos capilares.

Tipicamente, a adição de polímeros à fase aquosa é feita com o objetivo de aumentar a viscosidade da água e assim diminuir a razão de mobilidade entre as fases. Esta redução na razão de mobilidade contribuiria para uma melhora na eficiência de varrido do reservatório.

Resultados apresentados recentemente na literatura mostram que as soluções poliméricas podem levar também a uma redução da saturação residual de óleo. Porém, os mecanismos associados a esta redução não são bem entendidos.

A análise do processo de deslocamento de óleo em escala microscópica por soluções poliméricas foi estudada através de experimentos conduzidos em um micromodelo de vidro como representação de um meio poroso. Foi montada uma bancada composta pelo micromodelo, uma bomba de seringa, conexões, um microscópio e um computador para obter imagens da evolução das fases durante o processo de deslocamento de óleo. Foram desenvolvidos procedimentos experimentais para a injeção de três fases aquosas (água deionizada, solução de glicerina e solução de poli(óxido de etileno)).

Primeiramente, foi feita a injeção com água para a comparação dos resultados, foi então utilizada uma solução de glicerina com $51 \%$, cuja viscosidade é aproximadamente a mesma da solução polimérica (PEO) utilizada com o objetivo de isolar os efeitos da elasticidade no processo de recuperação.

Os resultados apresentados neste trabalho mostram claramente o efeito elástico da solução polimérica, manifestado, neste escoamento, pela alta viscosidade extensional em taxas de extensão altas. A alta viscosidade extensional aumenta a diferença de pressão no escoamento da fase aquosa, 
mobilizando gânglios cada vez menores. As imagens obtidas para o caso de injeção de solução polimérica mostram apenas gânglios pequenos de óleo preso, levando a uma queda significativa da saturação residual de óleo.

É importante observar que o efeito elástico só tornou-se relevante para vazões bem altas, que leva a altas taxas de extensão no escoamento na escala de poros.

\section{1.}

\section{Sugestões}

Os resultados mostram que o efeito elástico ocorre somente para escoamentos que apresentam taxa de extensão alta o suficiente. No caso explorado neste trabalho, isso só ocorreu na vazão mais alta testada.

Seria interessante ampliar o estudo apresentado para outras geometrias do espaço poroso, abordando novos valores de porosidade e permeabilidade. Espaço poroso com razões de contração da geometria da garganta de poros menores levam a taxas de extensão maiores.

Realizar testes utilizando polímeros com diferentes tempos de relaxação e estudar diferentes formas de injeção, como por exemplo, garantir certa saturação de água, conhecida como água conata, no micromodelo para reproduzir no experimento o que ocorre em reservatórios reais. Além da injeção alternada de água e soluções poliméricas.

O modelo utilizado para representar o meio poroso é bidimensional. Apesar do modelo apresentar as características básicas de um espaço poroso, o fato do mesmo ser bidimensional limita os possíveis caminhos seguidos por ambas as fases. Seria interessante ampliar os estudos usando um modelo 3-D transparente e microscopia confocal para visualizar a distribuição das fases e suas respectivas saturações após o processo de injeção de diferentes soluções poliméricas. 
5

\section{Referências Bibliográficas}

AFSHARPOOR, A. et al. CFD modeling of the effect of polymer elasticity on residual oil saturation at the pore-scale. Journal of Petroleum Science and Engineering, v. 94-95, p. 79-88, 2012.

BARTOLOMEU, L. S. P.; CARVALHO, M. S. Capillary network model of polymeric solution flow in porous media. $23^{\text {rd }} \mathrm{ABCM}$ International Congress of Mechanical Engineering, 2015. No prelo.

BEREJNOV, V.; DJILALI, N.; SINTON, D. Lab-on-chip methodologies for the study of transport in porous media: energy applications. Lab on a chip, v. 8 , n. 5, p. 689-693, 2008.

BUCHGRABER, M. et al. The displacement of viscous oil by associative polymer solutions. Proceedings - SPE Annual Technical Conference and Exhibition, v. 1, p. 78-96, 2009.

GREEN, D. W.; WILLHITE, G. P. Enhanced Oil Recovery. SPE Textbook, v. 6, 1998.

GUITIÁN, R. Evolução dos Conceitos de Polímero e de Polimerização. Plástico Moderno, v. 246, p. 38-42, 1994.

KUMAR GUNDA, N. S. et al. Reservoir-on-a-Chip (ROC): A new paradigm in reservoir engineering. Lab on a Chip, v. 11, n. 22, p. 3785, 2011.

MONTALVO, M. Escoamento de Emulsões Óleo em Água Através de Microcapilares. Dissertação de Mestrado. Departamento de Engenharia Mecânica da Pontifícia Universidade Católica do Rio de Janeiro, 2008.

NILSSON, M. A. et al. Effect of fluid rheology on enhanced oil recovery in a microfluidic sandstone device. Journal of Non-Newtonian Fluid Mechanics, v. 202, p. 112-119, 2013.

RANJBAR, M. et al. Quantification and optimization of viscoelastic effects of polymer solutions for enhanced oil recovery. $8^{\text {th }}$ Symp. on Enhanced Oil Recovery, SPE, p. 521-531, 1992.

SANDIFORD, B. B. Laboratory and Field Studies of Water Floods Using Polymer Solutions to Increase Oil Recoveries. Journal of Petroleum Technology, v. 16, n. 8, 1964.

SANTOS, P. É. et al. Métodos de Recuperação Secundária Convencionais. Cadernos de Graduação-Ciências Exatas e Tecnológicas (ISSN 1980-1777), 2010. 
SILVA, K. J. B. DA. Estudo da Interação do Poli(óxido de etileno) com os Surfactantes SDS e SDBS. Monografia. Departamento de Física da Universidade Federal de Viçosa, 2013.

SMITH, F. The Behavior of Partially Hydrolyzed Polyacrylamide Solutions in Porous Media. Journal of Petroleum Technology, v. 22, n. 2, 1970.

VARGAS, K. M. C. Processo de Deslocamento de Óleo em Micro Modelos de Meios Porosos por Injeção de Emulsão de Óleo em Água. Dissertação de Mestrado. Departamento de Engenharia Mecânica da Pontifícia Universidade Católica do Rio de Janeiro, 2014.

WANG, D. et al. Viscous-Elastic Polymer Can Increase Micro-Scale Displacement Efficiency in Cores. Acta Petrol. Sinica, v. 21, n. 5, p. 4A,45-51, 2000.

WANG, W. Viscoelasticity and Rheological Property of Polymer Solution in Porous Media. Journal of Jianghan Petroleum Institute, v. 16, p. 54-57, 1994.

WEI, B. et al. Oil displacement mechanisms of viscoelastic polymers in enhanced oil recovery (EOR): a review. Journal of Petroleum Exploration and Production Technology, p. 113-121, 2013. 


\section{A \\ Código em MATLAB}

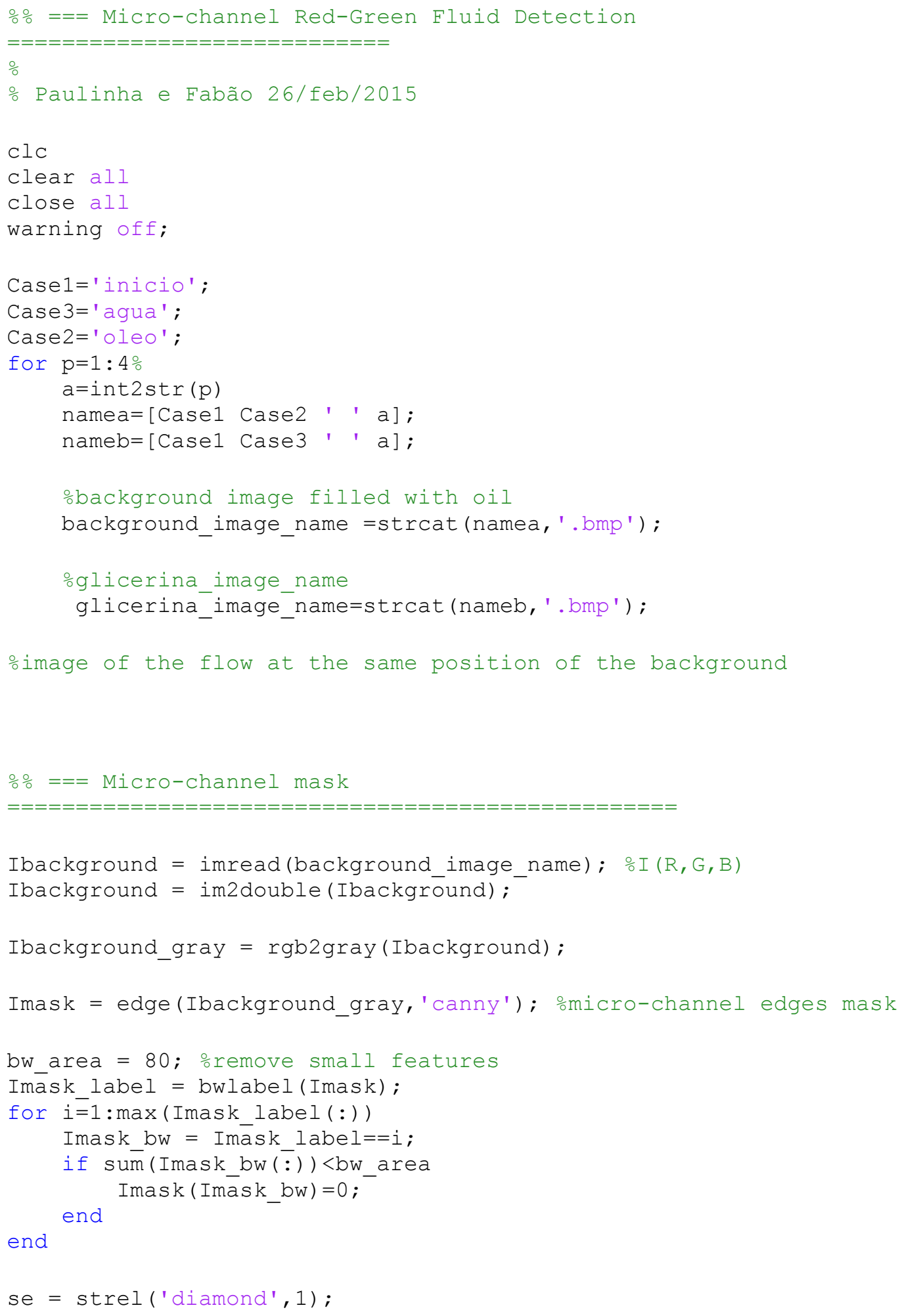




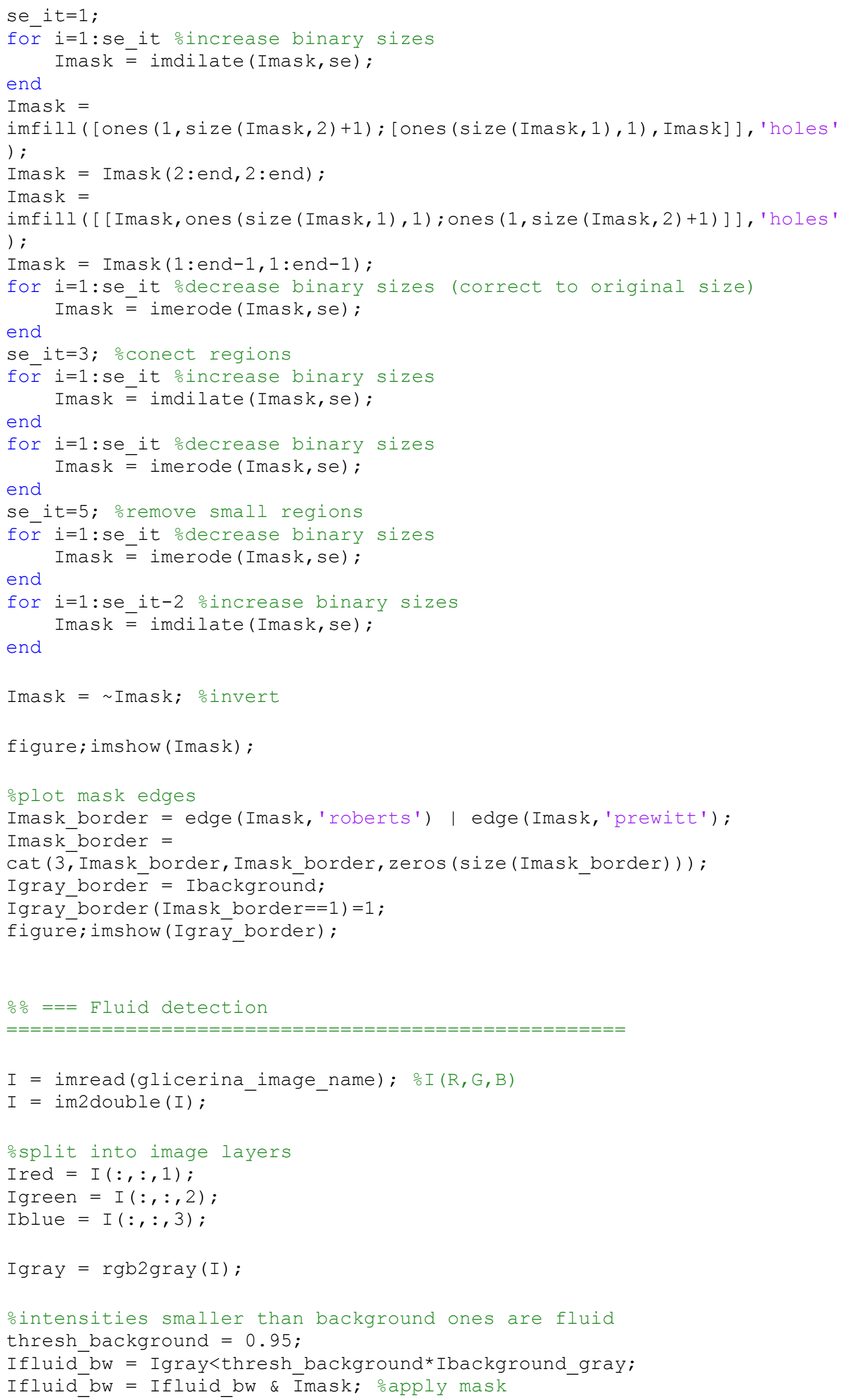




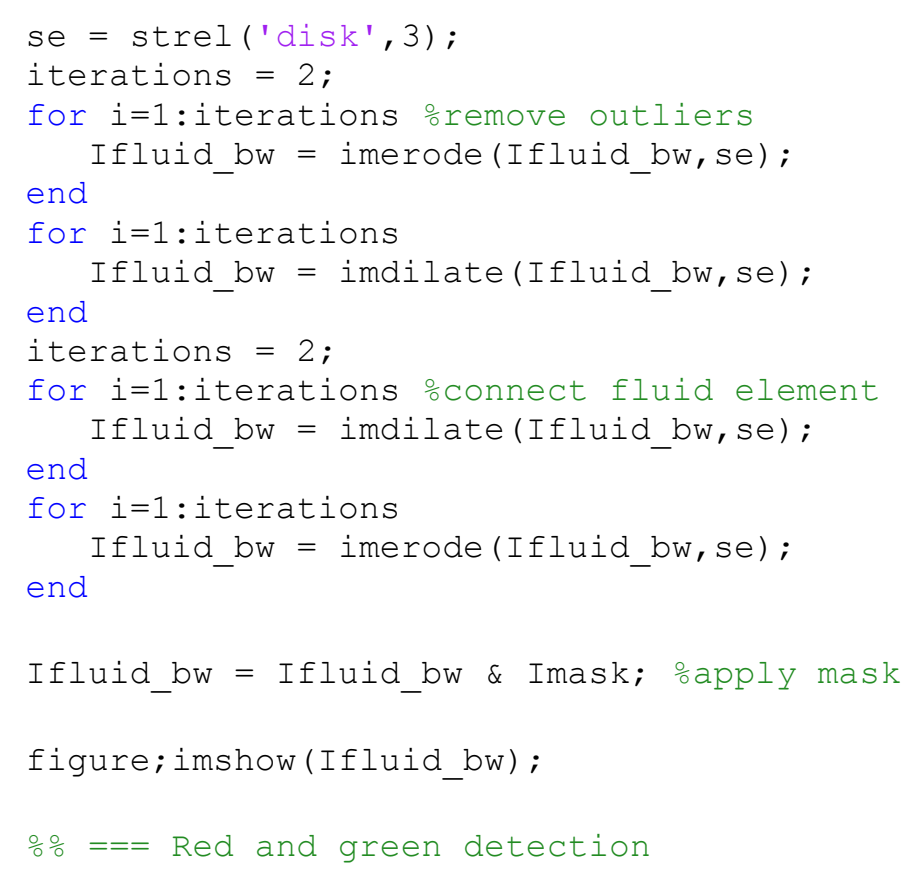

Ired_bw $=\operatorname{zeros}(\operatorname{size}(I, 1), \operatorname{size}(I, 2))$;

Igreēn bw $=\operatorname{zeros}(\operatorname{size}(I, 1), \operatorname{size}(I, 2))$;

Ifluid_label = bwlabel(Ifluid_bw);

Ired_b $\overline{\mathrm{w}}=$ Ifluid_bw;

\% for $i=1: \max (\bar{I} f l u i d$ label $(:))$

\% Ifluid_label_b $\overline{\mathrm{w}}=$ Ifluid_label==i;

\% $\quad$ ored intensity bigger thān others in main part of conected fluid

o if (sum(Ired(Ifluid_label_bw) >Igreen(Ifluid_label_bw) \&...

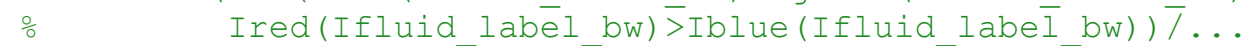

$\therefore \quad$ sum(Ifluid $\bar{l}$ label $\bar{b} w(:)))>0.5$

olse ogreen Ired $\mathrm{b} \bar{w}($ Ifluid label bw) $=1$;

$\circ$

ㅇ end end

$\div \%==$ Plot

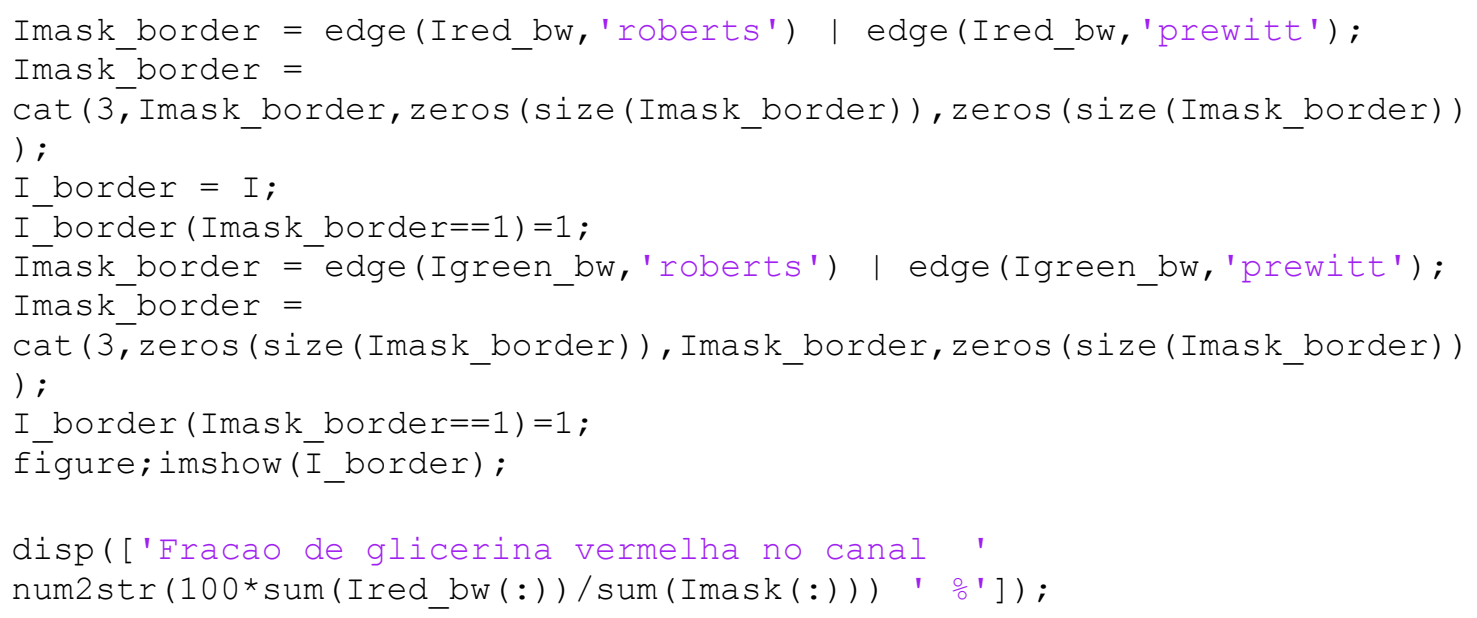




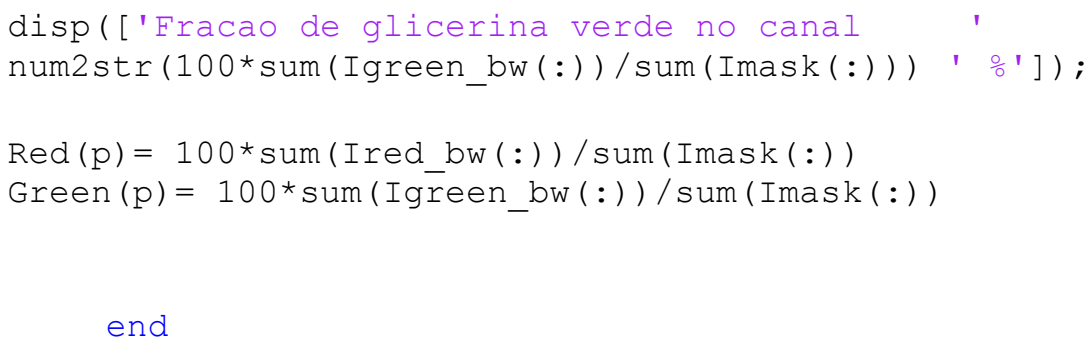

